\title{
Why Are There So Few Black Lawyers in Corporate Law Firms An Institutional Analysis
}

\section{Citation}

David B. Wilkins and G. Mitu Gulati, Why Are There So Few Black Lawyers in Corporate Law Firms--An Institutional Analysis, 84 Calif. L. Rev. 493 (1996).

\section{Published Version}

http://scholarship.law.berkeley.edu/californialawreview/vol84/iss3/1/

\section{Permanent link}

http://nrs.harvard.edu/urn-3:HUL.InstRepos:13548823

\section{Terms of Use}

This article was downloaded from Harvard University's DASH repository, and is made available under the terms and conditions applicable to Other Posted Material, as set forth at http:// nrs.harvard.edu/urn-3:HUL.InstRepos:dash.current.terms-of-use\#LAA

\section{Share Your Story}

The Harvard community has made this article openly available.

Please share how this access benefits you. Submit a story.

Accessibility 


\section{California Law Review}

Volume 84 | Issue 3

Article 1

May 1996

\section{Why Are There So Few Black Lawyers in Corporate Law Firms--An Institutional Analysis}

David B. Wilkins

G. Mitu Gulati

Follow this and additional works at: http://scholarship.law.berkeley.edu/californialawreview

\section{Recommended Citation}

David B. Wilkins and G. Mitu Gulati, Why Are There So Few Black Lawyers in Corporate Law Firms--An Institutional Analysis, 84 CAL. L. Rev. 493 (1996).

Available at: http://scholarship.law.berkeley.edu/californialawreview/vol84/iss3/1

This Article is brought to you for free and open access by the California Law Review at Berkeley Law Scholarship Repository. It has been accepted for inclusion in California Law Review by an authorized administrator of Berkeley Law Scholarship Repository. For more information, please contact jcera@law.berkeley.edu. 


\title{
California Law Review
}

\begin{tabular}{lll}
\hline \hline VoL. 84 & MAY 1996 & No. 3 \\
\hline \hline
\end{tabular}

Copyright $\odot 1996$ by California Law Review, Inc.

\section{Why Are There So Few Black Lawyers in Corporate Law Firms? An Institutional Analysis}

\author{
David B. Wilkins $†$ \\ G. Mitu Gulati††
}

TABLE OF CONTENTS

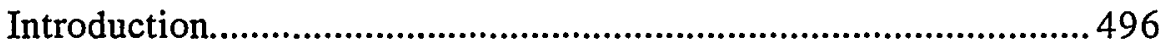

I. Defining the Problem............................................................501

A. Are Blacks Underrepresented in Corporate Firms? ............... 502

B. Why Study Institutions and Incentives? ..............................506

1. Differential Abilities ....................................................506

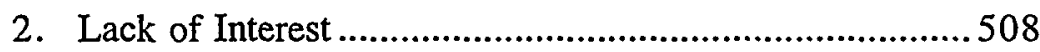

\section{Copyright $\odot 1996$ California Law Review, Inc.}

$\dagger \quad$ Kirkland \& Ellis Professor of Law and Director, Program on the Legal Profession, Harvard Law School.

it Law clerk to Judge Sandra L. Lynch, United States Court of Appeals for the First Circuit.

The authors wish to thank Ian Ayres, Lee Buchheit, Janet Bauman, Elizabeth Chambliss, Steve Choi, Sarah Cooleybeck, Howard Erlanger, Laurenn Edelman, Richard Epstein, Marc Galanter, Bryant Garth, Gibson Gayle, Robert Gordon, Lani Guinier, Andrew Guzman, Terence Halliday, Gloria Howard, Mark Ramseyer, Richard Revesz, Steven Shavell, Patrick Shin, Reva Siegel, Cass Sunstein, David Thomas, and Tim Wilkins for their generous comments on earlier drafts. We are particularly grateful to Professor David Charny, not only for his insights upon which many of our theories are based, but also for his continuing encouragement of this ongoing project. We also thank Cleary, Gottlieb, Steen \& Hamilton for giving Mr. Gulati both encouragement and time to work on this project while he was an associate there. In addition, Professor Wilkins thanks the University of California at Berkeley, Boalt Hall School of Law, Morrison \& Foerster, and the Robert D. and Leslie Kay Raven Trust for their generous support of the lecture series at Boalt Hall where these ideas were first presented. Richard Kilbride, Yan Senouf, and Maura Kelley provided invaluable assistance. This article is dedicated to the loving memory of Professor John R. Wilkins, who was a member of the Boalt Hall faculty from 1964 until his death in 1976, and to Albert Maule, whose keen insights about the problems faced by blacks in corporate firms advanced our thinking immeasurably. 


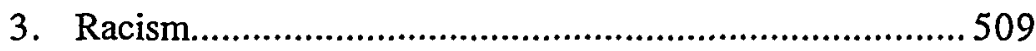

4. Preaching to the Unconverted....................................5511

C. Affirmative Action......................................................... 512

II. The Model: Monitoring Among the Human Capitalists ...............514

A. Discrimination in High-Level Jobs .................................... 517

1. Subjectivity and Monitoring ......................................518

2. When It's Cheaper to Overpay .......................................5 518

3. Tournament Theory …................................................519

4. "Efficient" Discrimination .........................................5520

B. Making Elite Law Firms....................................................523

1. Good Lawyers are Made, Not Born...............................5524

2. An Efficient Model in an Age of Opportunism...............530

a. High Salaries...........................................................550

b. Pyramiding..........................................................534

c. Tracking and Training............................................537

III. The Application: Mapping The Racial Law of Averages.............. 542

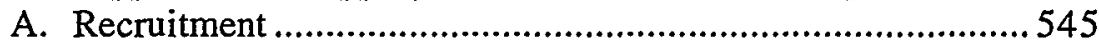

1. The Process ................................................................5 546

2. Signals and Signaling: Stocking the Pipeline and

Protecting the Franchise............................................... 549

3. Race and Recruiting.....................................................554

B. Retention, Promotion, and Survival.....................................564

1. Monitoring, Mentoring, and Marketing: Getting on the Training Track...................................................55 565

2. Concrete Ceilings and Slippery Floors: The Black Experience in Corporate Firms ....................................... 568

a. Mentoring and Irrationality.....................................568

b. Visibility and Tokenism.........................................5 571

c. Bringing the Outside In.............................................5572

d. Rational Strategies in the Face of Reasonable Fear....574

i. Low-Risk Strategies............................................554

ii. High-Risk Strategies: The Litigation Trap ...........577

e. The Revolving Door...............................................558

f. Unequal Partners...................................................558

i. The External Market.........................................582

ii. The Internal Market: Getting the Franchise ........583

IV. The Solution(s)?: Finding Efficient Responses to Efficient

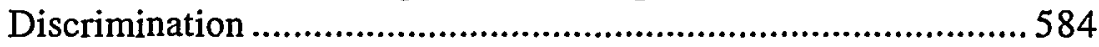

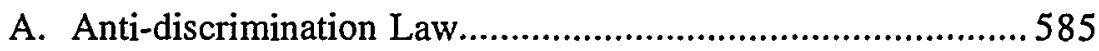

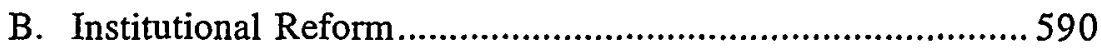


C. Diversity Training ......................................................... 592

D. Stimulating Demand .......................................................595

E. Affirmative Action........................................................ 598

1. Standards.......................................................60 600

2. Effort: Lowering the Price of the Ticket to the Tournament................................................ 602

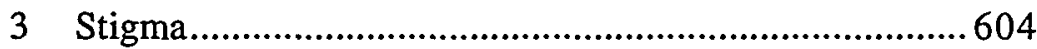

Conclusion: Choosing a New Path............................................605

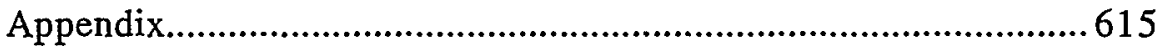




\title{
Why Are There So Few Black Lawyers in Corporate Law Firms? An Institutional Analysis
}

\author{
David B. Wilkins \\ G. Mitu Gulati
}

Although the number of black students graduating from law schools has increased significantly in recent decades, blacks still make up a very small minority of the lawyers working in large corporate law firms. Available data indicate that these firms hire few blacks, and that those they do hire are more likely than their white peers to leave the firms before becoming partners. Conventional explanations blame the underrepresentation of blacks in corporate firms on either the racism of firms and their clients, or a shortage of qualified, interested black candidates. While acknowledging that in some instances these factors may help to explain the problem, this Article looks behind them to examine institutional factors that tend to perpetuate the existing underrepresentation. Specifically, the Article shows how the ways in which large corporate firms recruit and train lawyers tend both to shield discriminatory choices between black and white candidates from any competitive disadvantage, and to discourage black law students and lawyers from investing in skills that will enable them to succeed within corporate firms. Thus, the Article argues, firms' hiring and training decisions both shape and are shaped by the strategic choices of black candidates, with the net effect of keeping all but a few blacks from being hired and succeeding in the firm setting. Finally, this Article explores the implications of these incentives for five commonly proposed tools for diversifying corporate law firms: anti-discrimination laws, race-neutral institutional reforms, diversity education within firms, demand-creation initiatives, and supply-side initiatives to encourage hiring and promotion of black lawyers.

\section{INTRODUCTION}

This Article addresses what for many is an uucomfortable reality: Despite a substantial increase in the uumber of black students attending law school over the last forty years, African Americans still constitute only a tiny percentage of the associates and partners working 
in the nation's largest corporate law firms. ${ }^{1}$ Given the legal profession's role in championing the principles of non-discrimination and equality of opportunity, this reality is particularly troubling. More generally, however, the fact that blacks have had little success breaking into the upper echelons of the elite bar is emblematic of a deeper and more intractable set of problems facing those interested in workplace integration.

Forty years after the Supreme Court's landmark decision in Brown v. Board of Education, ${ }^{2}$ society has made substantial progress toward eradicating the kind of overtly racist policies that excluded blacks from virtually every desirable sector of the economy. For many blacks, these changes have produced a dramatic growth in income and opportunity. In recent years, however, it has become painfully clear that simply dismantling America's version of apartheid has not produced economic parity between blacks and whites. ${ }^{3}$ Although poor blacks have benefited the least from the civil rights revolution, "high level" jobs in business and the professions have also proved surprisingly resistant to change. ${ }^{4}$ The fact that blacks have made so little progress in breaking into the corporate law firm elite-particularly at the partnership level-fits this larger pattern.

Commentators generally offer one of two explanations for this "glass ceiling" effect. The first, generally proffered by firms, posits a shortage of black applicants with both the qualifications and the interest necessary to succeed in the demanding world of elite corporate practice. $^{5}$ The second, most often articulated by blacks, blames the slow progress on continued racism both inside corporate firms and among the clients upon whom these entities depend for their livelihood. ${ }^{6}$

As we argue below, both the "pool problem" and continuing racism against blacks play important roles in determining the employment opportunities available to African American lawyers. Standing alone,

1. See infra Part I.A.

2. 347 U.S. 483 (1954).

3. See, e.g., William J. Wilson, The Declining Significance of Race: Blacks and Changing American Instirutions (1978) (arguing that poor blacks have benefited less than middle class blacks from the civil rights movement).

4. We borrow the phrase from Professor Bartholet, who was the first in the legal literature to identify this problem. See Elizabeth Bartholet, Application of Title VII to Jobs in High Places, 95 Harv. L. Rev. 945 (1982). For an extensive evaluation of this phenomenon, see Fed. Glass Ceiling Comm'n, U.S. Dept. of Labor, Good for Business: Making Full Use of the Nation's CAPITAL (1995) [hereinafter Glass Ceiling Report].

5. See, e.g., Vance Knapp \& Bonnie K. Grover, The Corporate Law Firm-Can It Achieve Diversity?, 13 NAT'L BLACK L.J. 298, 305-06 (1994) (examining and critiquing the argument that the pool of qualified law graduates of color is small); Valerie Fontaine, Progress Report: Women and People of Color in Legal Education and the Legal Profession, 6 HASTINGS WOMEN's L.J. 27, 35-36 (1995).

6. See, e.g., Knapp \& Grover, supra note 5, at 303. 
however, each explanation begs important questions. The "pool problem" explanation begs the question of whether the existing hiring and promotion criteria utilized by elite law firms to determine who is in the pool fairly and accurately predict future productivity. The racism story, on the other hand, fails to explain why firms that discriminate by refusing to hire or promote qualified black lawyers do not suffer a competitive disadvantage when those workers are employed by their competitors.

In order to arrive at a more thorough understanding, we must move beyond this familiar dichotomy. We do so by taking a closer look than either of the standard explanations at how corporate firms structure, and are structured by, the relevant markets for labor and clients. ${ }^{7}$ Our interest in this neglected institutional dimension is the product of our prior work on race, professionalism, and markets. One of us is engaged in the ongoing study of the legal profession with particular attention to the experiences of black lawyers. ${ }^{8}$ The other is studying how particular market conditions allow firms to insulate some kinds of discriminatory decisionmaking from the disciplining effects of competition.' In this Article, we seek to combine these two perspectives by offering a preliminary account of how corporate firms recruit and retain lawyers and why these practices may adversely affect the employment prospects of black lawyers. ${ }^{10}$

7. In this respect, our account is connected to recent "structuralist" theories of workplace discrimination. See, e.g., Rosebeth M. KANTER, MEN AND WOMEN OF THE CoRporation (I977); Martha Chamallas, Structuralist and Cultural Domination Theories Meet Title VII: Some Contemporary Influences, 92 Mich. L. Rev. 2370 (1994); Vicki Schultz, Telling Stories About Women and Work: Judicial Interpretations of Sex Segregation in the Workplace in Title VII Cases Raising the Lack of Interest Argument, 103 HARv. L. Rev. 1749 (1990). As will emerge below, however, there are important differences between these approaches and the account that we defend here. For an insightful discussion and critique of the limits of traditional structural accounts in this field, see Elizabeth Chambliss, Organizational Determinants of Law Firm Integration (AM.U. L.REv., forthcoming 1996). Our thinking on these issues has been greatly influenced by Professor Chambliss' work.

8. See, e.g., David B. Wilkins, Introduction: Race in Context, in ANTHonY AppiaH \& AMY Gutmann, Color Consciousness: The Political Morality of Race (forthcoming 1996); David B. Wilkins, Social Engineers or Corporate Tools? Brown v. Board of Education and the Conscience of the Black Corporate Bar, in RACE, LAW, AND CulTuRE: REFLECTIONS ON BROWN v. BOARD OF EDUCATION (Austin Sarat ed., forthcoming 1996) [hereinafter Wilkins, Social Engineers]; David B. Wilkins, Race, Ethics, and the First Amendment: Should a Black Lawyer Represent the Ku Klux Klan?, 63 G.W.U. L. Rev. 746 (1995) [hereinafter Wilkins, Race, Ethics, and the First Amendment]; David B. Wilkins, Two Paths to the Mountaintop? The Role of Legal Education in Shaping the Values of Black Corporate Lawyers, 45 STAN. L. REv. 1981 (1993) [hereinafter Wilkins, Two Paths]. Professor Wilkins is currently writing a book on black corporate lawyers.

9. See generally David Charny \& Mitu Gulati, Efficiency Wages, Tournaments and Discrimination: A Theory of Employment Discrimination for "High Level" Jobs, Joln M. Olin Center for Law, Economics, and Business, Discussion Paper No. 182, Harvard Law School (March 1996).

10. See Edward L. Rubin, The New Legal Process, the Synthesis of Discourse, and the Microanalysis of Institutions, 109 HARv. L. REv. 1393 (1996) (suggesting a similar methodological synthesis). 
Our argument proceeds in five parts. Part I briefly summarizes the available data on blacks in corporate law practice and defends our claim that an institutional analysis is a necessary component of any plausible explanation for these numbers. We also set out our reasons for initially bracketing (to the extent possible) the impact of affirmative action on law firm hiring and promotion practices. We return to this issue in Part IV.

In Part II, we present a stylized model of the contemporary elite corporate law firm. The model is premised on two related features of professional work: the inherent subjectivity of quality assessments and the difficulty and expense of monitoring. In response to these realities, we posit that it is efficient for firms to adopt the following tripartite strategy: high wages to create a large pool of available workers and to motivate those lawyers who are hired to work with relatively little supervision; a high associate-to-partner ratio, thus further encouraging associates to work hard in the hopes of becoming partners while at the same time allowing the firm to spread legal work among many lawyers with varying levels of knowledge and skill at the lowest possible cost; and a tracking system whereby the pool of associates is divided into those who will receive scarce training resources and those who will work on relatively undemanding assignments.

These three institutional features of contemporary elite firms, we assert, disproportionately disadvantage black lawyers. ${ }^{11}$ Two tendencies contribute to this result. First, because firms hire a large number of associates from a pool that has been artificially inflated by high salaries and ask many of them to do relatively undemanding work, these institutions have little incentive to invest in obtaining detailed information about the quality of potential employees. Hence, individuals within the firm can use race as a factor in their decisionmaking without hurting the firm's bottom line. The same goes for retention and promotion. Decisions to invest scarce training resources in average whites as opposed to average blacks will not hurt the firm's chances of producing the small number of high quality partners that it needs to guarantee its productivity in future years. As a result, firms have little incentive to root out employment decisions that, either consciously or unconsciously, prejudice blacks or favor whites.

Second, because firms have no incentive to stop these practices, black lawyers in firms (as well as those contemplating joining firms) are more likely to choose human capital strategies that, paradoxically, de-

11. It is important to make clear from the outset that we do not claim that these practices only disadvantage blacks. Quite to the contrary; many whites are also disadvantaged by this system. Our point simply is that blacks as a group are more likely to bear the brunt of these practices for the reasons discussed in Part Ill. 
crease their overall chances of success in these environments. Since blacks reasonably believe that they face an increased risk that their abilities will be unfairly devalued or overlooked, they have an incentive to overinvest either in avoiding visible negative signals or in obtaining easily observable positive signals that clearly identify them as superstars. Both of these strategies, however, are potentially counterproductive to the extent that they diminish a black lawyer's opportunity or incentive to obtain the skills upon which success at the corporate law firm ultimately depends.

In Part III, we test our model against the limited amount of currently available empirical and anecdotal evidence on black corporate lawyers and our own preliminary research on black Harvard Law School graduates. This data is far too tenuous and incomplete to prove definitively the institutional dynamic we posit. Nevertheless, what information there is points in the direction predicted by our model. Although these institutions spend a considerable amount of time and money on recruiting, firms rely on a small number of easily visible and rankable criteria at the initial screening phase, while at the same time relying on subjective judgments about "personality" and "fit" (as opposed to other easily obtainable indicia of quality) during the less visible parts of the process. This combination of objective and subjective decisionmaking disadvantages black applicants by falsely conveying the impression that the visible and rankable criteria that firms rely on are tightly correlated with quality, while simultaneously allowing individuals within firms to discount a black candidate's signals based on subjective judgments about personality and fit. Similarly, when selecting associates to mentor and train, partners rely on a combination of a few objective signals and their own subjective judgments in order to determine which associates are likely to have the kind of viable long-term careers with the firm that make them good training prospects. Once again, the data suggests that blacks are less likely to be selected to receive this essential good. Finally, as our model predicts, black students and associates often react to these heightened barriers by choosing human capital strategies that further diminish their chances for success in this environment.

Part IV examines the implications of our analysis for five of the most commonly proposed solutions for diversifying corporate law firms: anti-discrimination laws such as Title VII, race-neutral institutional reforms such as formal training programs and associate review, educational initiatives such as diversity training, demand-creation initiatives designed to encourage corporate clients to hire black lawyers, and supply-side initiatives that encourage firms to make affirmative efforts to increase the number of blacks they hire and promote. Each of these mechanisms has the potential to improve oppotunities for black lawyers. 
The structural characteristics of the elite firms described in Part II, however, make it difficult for this potential to be realized.

Part V therefore concludes by briefly examing why elite firms might change these strucural impediements. Although we claim the existing structure is efficient, the argument that it is the only efficient response to the problems of subjectivity and monitoring ignores both historical contingencies that produced these practices and the unprecidented volitility of the market for elite firm services. Ironically, we believe that the sense of crisis that currently pervades not only elite firms, but the enitre legal profession, offers a unique opportunity to chart a new path that will enable there institutions to move closer to the ideals of fairuess and equality that constitute the best part of this country's legal tradition.

\section{Defining the Problem}

As the Article's title implies, two assumptions underlie our analysis. ${ }^{12}$ First, we assume that blacks are underrepresented in corporate law

12. Two additional preliminary points are in order. First, by limiting our focus to the problems of black lawyers, our analysis departs from the growing tendency among both academics and practitioners to treat these issues as merely a subset of the problems faced by all "minority" lawyers, or, even more generally, as part of an investigation of "minorities and women" in the profession. See, e.g., Carrie Menkel-Meadow, Culture Clash in the Quality of Life in the Law: Changes in the Economics, Diversification and Organizing of Lawyering, 44 CASE W. REs. L. REv. 621, 638 (1994) (discussing whether "women or other previously excluded groups" are likely to make unique contributions to the profession because of their status as "outsiders"); Rita H. Jensen, Minorities Didn't Share in Firm Growth, NAT'L L.J., Feb. 19, 1990, at 1; Frederick H. Bates \& Gregory C. Whitehead, Do Something Different: Making a Commitment to Minority Lawyers, A.B.A. J., Oct. 1990, at 78. Although there are important similarities between the experiences of black lawyers and others who historically have been denied full participation in the profession, important differences nevertheless remain-differences that are likely to affect black advancement in the law and elsewhere. See, e.g., ANDrew Hacker, Two Nations: Black and White, Separate, Hostile, UNEQUAL 5-28 (1992) (discussing the persistence and pervasiveness of racial stereotypesparticularly those concerning intellectual inferiority-directed against blacks as opposed to members of other groups). Empirical studies of the legal profession that disaggrogate data for women and various minority lawyers confirm this supposition. See, e.g., Chambliss, supra note 7 (discussing several significant differences among women, blacks, Hispanics, and Asians); 1 REPORT OF THE New York State Judicial Comm'N ON Minorities 74-113 (1991) [hereinafter N.Y. Report]. Nevertheless, because much of the data discussing diversity issues in this area is not disaggregated by race or gender, we are sometimes forced to rely on statistics about "minorities" as a surrogate for information about blacks. See, e.g., infra notes 19, 391 and accompanying text. This aggregation makes it particularly difficult to investigate the unique experiences of black women.

Second, by focusing on the problems of blacks in corporate firms, we do not mean to convey the impression that these institutions are either typical of, or more important than, other settings in which black lawyers work. See Barbara A. Curran \& Clara N. Carson, Supplement to the Lawyer Statistical Report: The U.S. Legal Profession in 1988, at 21 (1991) (noting that firms of more than 100 lawyers comprise less than $10 \%$ of the profession); Wilkins, Two Paths, supra note 8, at 1991-92 (noting that corporate law may not be the best arena for black lawyers to pursue social justice). Instead, we simply assert that, given that these institutions sit atop the economic and status hierarchy of the profession, society ought to care whether blacks are systematically less likely to succeed in these environments than whites. 
firms. Second, we hypothesize that this underrepresentation is due in part to the way in which the structural characteristics of corporate firms shape the strategic choices of black lawyers. In Sections A and B of this part, we justify both assumptions. In Section $C$, we explain why we have chosen as a preliminary matter to bracket questions regarding affirmative action.

\section{A. Are Blacks Underrepresented in Corporate Firms?}

One's feeling about the progress made by large corporate law firms in hiring and retaining black lawyers is likely to be influenced by the time frame one selects to examine the problem. Looking from the perspective of the corporate bar in the late $1960 \mathrm{~s}$, the numbers might look relatively good. Thus, when Erwin Smigel conducted his famous study of Wall Street firms in the 1960s, he reported that "[i]n the year and a half that was spent interviewing, I heard of only three Negroes who had been hired by large law firms. Two of these were women who did not meet the client."13 Integration did not come much sooner in other parts of the country. ${ }^{14}$ Compared to this dreary portrait, recent numbers seem impressive. For example, the National Law Journal reports that as of 1995 there were more than 1,641 blacks working in the nation's 250 largest firms, of whom 351 were partners. ${ }^{15}$

Viewed against the rapid expansion in corporate firms during the last twenty-five years and the dramatic growth in the number of women lawyers working in this area, the foregoing numbers are a good deal less inspiring. ${ }^{16}$ Thus, although there has been a significant growth in the absolute number of black lawyers in corporate firms, the percentages remain microscopically small. The same 1996 National Law Journal survey reveals that blacks constituted just $2.4 \%$ of the lawyers in corporate firms, and, more importantly, just over one percent of the partners. ${ }^{17}$ These percentages have remained relatively constant for the last 15

13. Erwin O. Smigel, The Wall Street Lawyer: Professional Organizational Man? 45 (1969).

14. See Geraldine R. Segal, Blacks in the Law: Philadelphia and the Nation 21516 (1983) (reporting that before the mid-1970s, only a handful of black lawyers worked in private firms).

15. Ann Davis, Big Jump in Minority Associates, But ..., NAT'L L.J., April 29, 1996, at 1; Claudia MacLachlan \& Rita H. Jensen, Progress Glacial for Women, Minorities, Nat't. L.J., Jan. 27, 1992, at 1, 31 (reporting that in 1991, there were 1,311 black lawyers of 287 were partners).

16. On the growth of large law firms, and possible reasons for this growth, see infra note 109 and accompanying text. For a comparison of the progress of women and blacks, see Jcnsen, supra note 12, at I (comparing limited progress by minorities with substantial progress by women).

17. Davis, supra note 15, at 1; see Robert L. Nelson, The Futures of American Lawyers: A Demographic Profile of a Changing Profession in a Changing Society, 44 CASE W. Res. L. REv. 345, 379 (1994) (reporting that among 250 largest law firms only $2.2 \%$ of associates and $0.9 \%$ of partners were black). 
years. ${ }^{18}$ Moreover, these percentages lag behind those achieved by other legal employers. For example, minorities constitute $17.2 \%$ of the lawyers employed by federal, state, and local government agencies in the Chicago metropolitan area, as compared to the $3.6 \%$ of the attorneys in large Chicago firms. ${ }^{19}$ At higher levels, the comparison is even more lopsided. Minority lawyers occupy $19.5 \%$ of the supervisory positions in these government offices as compared to $1.6 \%$ of the partnerships at large Chicago firms. ${ }^{20}$ Indeed, although the contrast is less dramatic, law firms have also failed to equal the success achieved by some of their corporate clients. Blacks occupy $2.5 \%$ percent of all of the executive or management level jobs in private sector industries-still well below the percentage of blacks in the general population, but more than double the percentage of blacks who are partners in elite firms. ${ }^{21}$ In certain industries, black men and women have done significantly better. For example, in the communications industry, black men hold $3.7 \%$ of all executive, administrative, and managerial positions, while black women occupy an additional $4.9 \%$, bringing the total black participation to $8.6 \% .22$

Standing alone, however, statistics can not answer the question of whether blacks are underrepresented in corporate firms. To reach an informed judgment on this issue, one must have some idea about the number of blacks in the pool of people who are qualified to become corporate lawyers. Once again, one's vantage point is key. For example, if the relevant pool is all law school graduates, there is little doubt that blacks are seriously underrepresented in corporate firms, particularly at the partnership level. Since the mid-1970s, blacks have consistently constituted more than six percent of the students enrolled in law school-a percentage far higher than the current African American rep-

18. In I981, the percentages for black associates and partners were $2.3 \%$ and $0.47 \%$ respectively; in $1989,2.22 \%$ and $0.91 \%$. Jensen, supra note 12 , at 28 . In 1991 , the corresponding percentages were 2.0 and 1.1. MacLachlan \& Jensen, supra note 15, at 31. Elizabeth Chambliss reports comparable numbers for her sample of large law firms between 1980 and 1990 . See Chambliss, supra note 7, at 76 . Given the increase in the size and number of corporate firms during this period, one might have expected more than a proportionate increase in the number of black lawyers, particularly given their stark underrepresentation in the past. See Knapp \& Grover, supra note 6, at 302-03. As we argue below, the percentage increase between 1991 and 1995 is most likely due to the adoption of goals and timetables for minority hiring and promotion in several cities. See infra notes 32-33, 403-404 and accompanying text.

19. Harvey Berkman, Government Tops Firms in Building Diversity, CHI. LAw., July 1993, at 1. This is one of many examples where the data on minorities is not disaggregated by race.

20. Id.

21. See Glass Celling Report, supra note 4, at 77 .

22. Id. at 79. Blacks in the insurance and business services industries have also reached executive or managerial levels in greater numbers than their counterparts in corporate law practice (in insurance, $6.2 \%$ total, $3.2 \%$ for black men and 3.0\% for black women; in business services, $4.0 \%$ total, $3.5 \%$ for black men and $0.5 \%$ for black women). Id. 
resentation among law firm associates and partners cited above, even if one adjusts for the time it took for these newcomers to enter the system. ${ }^{23}$

Many would assert, however, that the population of all law school graduates is not the relevant pool. Traditionally, corporate firms have hired most of their incoming associates from elite law schools, such as Harvard and Yale. ${ }^{24}$ In addition, those who secure jobs in this sector often have other traditional signals of academic success, such as high grades, law review memberships, and judicial clerkships. ${ }^{25}$

As we indicate in Part III, the claim that law firms have always employed a set of meritocratic hiring criteria that limit the eligible pool to elite law school graduates at the top of their class is belied by the historical record. ${ }^{26}$ Even if one accepts this basic definition of the relevant pool, however, blacks may still be underrepresented. Thus, Robert Nelson reported in 1988 that the percentage of minority students attending the leading law schools from which corporate firms generally recruit "is considerably higher than the proportion of minorities among even the youngest cohorts of lawyers in firms."27

More importantly, whatever the traditional patterns of law firm recruitment were, the tremendous growth in the size of these institutions during the last twenty-five years has resulted in a significant expansion in the schools from which firms interview and recruit. For example, in Nelson's study of Chicago corporate firms, only $18.4 \%$ of incoming

23. See Ken Myers, Statistics Show Minorities Have Bigger Share of Lower Enrollment, NAT'L L.J., Mar. 22, 1993, at 4 (reporting that blacks constitute 6.7\% of law students); see also Lewis A. Komhauser \& Richard L. Revesz, Legal Education and Entry into the Legal Profession: The Role of Race, Gender, and Educational Debt, 70 N.Y.U. L. REv. 829, 862-63 (1995) (reporting that "in 1991 African-Americans and Latinos were still only $4.3 \%$ of associates at elite law firms, even though they comprised $8.7 \%$ of individuals graduating from law school between 1984 and $1990 \ldots$ [T] he underrepresentation was even starker among partners.") (footnotes omitted).

24. See Marc Galanter \& Thomas Palay, Tournament of Lawyers: The Transformation of the Big Law Firms 24 (1991); Robert L Nelson, Partners with Power: The Social Transformation of the LaRge Law Firm 131-33 (1988). Needless to say, exactly which law schools qualify for this designation is a matter of some dispute-particularly among law schools themselves. Although no list is therefore uncontroversial, for purposes of this study, we consider the following eleven law schools to be elite: Harvard, Yale, Stanford, Boalt Hall (University of California at Berkeley), University of Michigan, New York University, University of Virginia, University of Chicago, University of Pennsylvania, Columbia, and Northwestern. Cf. Chambliss, supra note 7, at 58 (using a list of thirteen schools).

25. Galanter \& Palay, supra note 24, at 24.

26. See infra notes 172-174 and accompanying text.

27. NELSON, supra note 24, at 131 . For example, Chambliss reports that minority students made up $12 \%$ to $18 \%$ of classes graduating from thirteen elite law schools bctween 1980 and 1990 . Chambliss, supra note 7, at 80 . Neither Nelson nor Chambliss breaks this information down by race or provides data on class rank or other academic credentials. Nevertheless, it is clcar many of these students are black. For example, the percentage of blacks at Harvard Law School increascd from 7.9\% in 1980 to $10.5 \%$ today. Leigh Ann Mort and Milton Moskowitz, The Best Law Schools for Blacks, J. of Blacks in Higher Education, Summer 1994, at 58. 
associates between 1970 and 1974 graduated from local or regional law schools. ${ }^{28}$ Between 1975 and 1988, that number had more than doubled to $37.5 \% .^{29}$ Today, the hiring needs of elite corporate firms are so great that their demand probably could not be satisfied if they hired every graduate in the top half of the class from the nation's top twenty law schools. $^{30} \mathrm{~A}$ definition of the pool that includes only those with "traditional" credentials, therefore, understates the relevant employment market.

Finally, even if we could accurately identify the criteria that law firms actually employ in choosing among prospective applicants, these criteria would only define the pool of qualified applicants (as opposed to the pool of applicants with a realistic chance of being selected) to the extent that there is a relatively tight correlation between these signals and the skills that are necessary to perform the job proficiently. It is precisely this linkage, however, that many critics bitterly attack. ${ }^{31}$ In Part $\mathrm{II}$, we argue that there is merit to this criticism, albeit for reasons different than those generally advanced. As a result, we assume that the pool of "qualified" applicants is larger than current hiring practices would lead one to believe, and, correspondingly, that blacks are in fact underrepresented.

Although our assumption that blacks are underrepresented cannot entirely be separated from the merits of our theory, it is consistent with a broad array of recent initiatives desigued to increase the number of minority lawyers in corporate firms. In 1986, the American Bar Association formed the Commission on Minorities im the Profession. One of the Commission's central goals has been to increase corporate law firms' hiring and retention of minority lawyers, whom the Commission asserts are seriously underrepresented in this sector. ${ }^{32}$ In the intervening decade, at least thirteen state, county, and municipal bar associations have launched similar efforts. ${ }^{33}$

28. NeLSON, supra note 24 , at 133 .

29. Id.

30. Howard I. Bernstein, Does a Hiring Crisis Threaten the Profession?, NAT'L LJ., Dec. 28, 1987-Jan. 4, 1988, at 20 (reporting that approximately 3,040 students graduate in the top halves of their classes from top-twenty law schools each year, while in 1987, 4,807 associates began work at the top 250 law firms).

31. See, e.g., Knapp \& Grover, supra note 6, at 305-06.

32. See Bates \& Whitehead, supra note 12, at 78 ("The ABA Commission on Opportunities for Minorities in the Profession... has indicted the legal community for its failure to give minority lawyers significant roles in large firms."); AMERICAN BAR Association CoMmission on Minorities IN the Profession, Five Year Report (1991); see also Wilma J.W. Pinder, When Will Black Women Lawyers Slay the Two-Headed Dragon: Racism and Gender Bias?, 20 PEPr. L. Rev. 1053, 1060 \& n.16 (1993).

33. See Committee on Minority Employment, The Bar association of San Francisco, 1993 INTERIM Report: Goals and Timetables for Minority Hiring aNd ADVANCEMENT 37 (1993) [hereinafter S.F. REPORT] (listing the following organizations as having 
In the absence of definitive information about current practices and the relationship between those practices and the substantive qualifications for being a successful corporate lawyer, ${ }^{34}$ it seems prudent to accept the opinion of these knowledgeable insiders that a problem does in fact exist. This is particularly so in light of the fact, as we explain in Part II, that the underrepresentation hypothesis is consistent with what one would expect to see given the institutional structure and practices of large firms. Before presenting that analysis, however, it is necessary briefly to examine three competing explanations for the relative shortage of blacks in corporate firms that would minimize (or in some cases deny) the importance of the institutional features we discuss.

\section{B. Why Study Institutions and Incentives?}

One can usefully divide the competing explanations for black underrepresentation in corporate firms into three categories: (1) that blacks and whites have differential abilities; (2) that blacks are less interested in corporate work; and (3) pervasive racism on the part of individuals within the firms or of the firms themselves. Although each of these theories advances our understanding of the variation we see between the success rates of blacks and whites in these institutions, each begs important questions that must be answered if one is to have a full explanation of this phenomenon. The institutional perspective we advocate helps to fill in these crucial gaps. It also responds to the concerns of those scholars and policy makers who are skeptical that race continues to be a significant obstacle for black Americans, and who doubt the efficacy of group-based policies to promote workplace integration.

\section{Differential Abilities}

Those who emphasize the importance of the traditional credentials for being hired by a corporate law firm often implicitly rely on empirical assumptions about the differential abilities of black and white applicants. These arguments come in two quite different forms. The first claims that blacks are inherently inferior to whites in terms of one or

established hiring and promotion goals: New York City Bar Association, San Francisco Bar Association, Boston Law Firm Group, Chicago Bar Association, Cleveland Minority Partners' Group, Colorado Law Firm Group, Connecticut Law Firm Group, District of Columbia Bar, Hispanic Bar Association of Houston, Los Angeles County Bar Association, New Jersey Law Firm Group, Philadelphia Bar Association, and Arizona State Bar). In addition, at least thirteen states have established task forces to study racial and ethnic bias in their court systems. Suellyn Scarnecchia, State Responses to Task Force Reports on Race and Ethnic Bias in the Courts, 16 HAMLINE L. REv. 923, 923 \& n.2 (1993) (listing Arizona, California, Connecticut, Florida, Hawaii, Iowa, Massachusetts, Michigan, Minnesota, North Dakota, New Jersey, New York, Oregon, Washington, and the District of Columbia).

34. On the general weakness of the existing data on the actual practices of corporate firms, see infra notes 164-167 and accompanying text. 
more attributes, for example intelligence, necessary for success in a corporate firm. ${ }^{35}$ The second approach rejects the claim that blacks are fundamentally inferior to whites (genetically or otherwise), but asserts that they nevertheless have acquired less of the human capital assets (that is, education, work skills, etc.) that it takes to succeed in this environment than their white peers. ${ }^{36}$

Like most others of good will, we reject the first of these arguments. Although a complete statement of the fallacy of this position is beyond the scope of this Article, as others have demonstrated in painstaking detail, the argument for innate or even deeply embedded racial differences in intelligence or any other relevant quality is based on either pseudo-science or quasi-racist premises. ${ }^{37}$ As we indicate below, however, the persistent myth of black intellectual inferiority continues to play an important role in shaping both the opportunities available to and the choices made by black lawyers.

The second variation on this theme, however, cannot be so easily dismissed. As we indicate in Part III, there is little reliable information on the relative attributes and performance of black and white law students and lawyers. Nevertheless, there is reason to suspect that black law school graduates may on average have fewer of the traditional markers of academic success than their white counterparts. ${ }^{38}$ Once again, it remains an open question whether these differences in credentials reflect actual differences in human capital that are likely to affect performance. But even assuming that there is a significant correlation, we still need to know why blacks invest less in their own development. We posit that the answer to this question is likely to depend upon the opportunities black lawyers face and the likelihood that investing in certain kinds of human

35. See, e.g., Dinesh D'Souza, The End of Racism: Principles for a Multiracial SOCIETY 431-76 (1995) (arguing that 1Q differences, whether caused by genetics or long-term environmental factors, are an important part of the reason that blacks do not succeed in certain settings); Richard Herrnstein \& Charles Murray, The Bell Curve: INTElligence and Class Structure in AMERICAN LIFE (1994) (arguing that differences in IQ largely account for the economic and educational differentials between blacks and whites); Linda S. Gottfredson, Societal Consequences of the $\mathrm{g}$ Factor in Employment, $29 \mathrm{~J}$. Vocatronal BeHAV. 379, 398-406 (1986) (arguing that in light of IQ differences between blacks and whites, blacks are overrepresented in most well-paying and prestigious positions).

36. See, e.g., GLenN C. Loury, ONe by ONe from the Inside OUt: Essays and Reviews ON RACE AND RESPONSIBILITY IN AMERICA 97 (1995) (arguing that income gaps between blacks and whites are now largely a matter of "supply side" factors such as "poorer quality and quantity of education and work experience" for black workers). Loury goes on to attribute these "supply side" differences to factors that are similar to those we discuss below. See infra notes 87-89 and accompanying text.

37. For a small sampling of the critique of the scientific and normative assumptions underlying the work of Herrnstein and Murray, among others, see Stephen J. Gould, Curveball, THE NEW YoRKER, Nov. 28, 1994, at 139; Leon J. Kamin, Behind the Curve, ScI. AM., Feb. 1995, at 99; see also Richard Lewontin, Biology as IDeOlogy 17-37 (1993).

38. See Richard L. ABel, AMERican Lawyers 102-04 (1989). 
capital will significantly improve those opportunities. In the world that we study, this opportunity calculus will be filtered through the institutional practices of large law firms. Understanding these practices is therefore a necessary component of any theory that seeks to explain racial differences in employment on the basis of a non-biological theory of differential ability.

\section{Lack of Interest}

This explanation offers an alternative account of why blacks do not invest in succeeding at corporate law firms, one based in preferences rather than incentives. According to this line of argument, many black students are uninterested in the work done by corporate law firms. Consequently, they are less likely to apply to these institutions and, if they do, leave after a relatively short time. ${ }^{39}$ Once again, there are reasons to suspect that this factor plays a contributing role. Black lawyers are disproportionately concentrated in the government and the not-for-profit sector..$^{40}$ In addition, given the historical connection between the black bar and the struggle for racial justice, many blacks come to law school intending to use their new skills to advance the interests of the African American community. ${ }^{41}$ Corporate law firms are not the obvious arena in which to pursue that goal.

Nevertheless, the claim that blacks are uninterested in corporate law firms is not supported by the available data. In their study of the first job choices of New York University and University of Michigan graduates, Kornhauser and Revesz discovered that after adjusting for grades, loans, law school activities, and even stated preferences, blacks were more likely to take jobs at corporate law firms than their white counterparts. ${ }^{42}$ If anything, blacks appear to be more interested in starting work at a corporate firm than whites.

Moreover, as Vicki Schultz has observed, one should be skeptical of claims that a particular group is underrepresented because of their

39. See, e.g., N.Y. REPORT, supra note 12, at 83 (suggesting that interviewers assume that blacks are not interested in private or business practice and prefer to work in government or other public service); S.F. REPORT, supra note 33, at 17 ("There was some sentment expressed by a few managing partners, although not stated by any minority interviewee, that minorities don't likc litigation or prefer to work in pro bono offices or other employement where their work is morc in sync with what managers perceive to be their personal politics.")

40. See Nelson, supra note 17, at 379 (reporting that one study found black lawyers were more than twice as likely as white lawyers to work for the government); J. Clay Smith, Career Patterns of Black Lawyers in the 1980's, 7 BLACK LJ. 75, 76 (1981) (estimating that in 1980, 32\% of black attorneys were in government practice).

41. See Wilkins, Social Engineers, supra note 8 (describing how Thurgood Marshell's legacy influences the current generation of black law students and lawyers).

42. See Kornhauser \& Revesz, supra note 23, at 931-34 (finding that African American and Latino graduates are underrepresented in 'non-elite for-profit jobs and overrepresented both in elite for-proflt jobs and in not-for-profit jobs). 
lack of interest-especially where the group has previously faced express discriminatory barriers to entry and the job in question is both prestigious and high paying. ${ }^{43}$ As Schultz demonstrates, firms can construct their use of labor in ways that will discourage applicants from certain groups from seeking these positions. An understanding of these institutional practices is therefore a necessary precondition to explaining why blacks "choose" careers other than corporate law practice.

\section{Racism}

To say that firms "construct" their use of labor in a manner that disadvantages blacks sounds as if this conduct is merely racism in a more sophisticated form. Critics of the slow progress towards integration in various sectors of the economy frequently make precisely this charge. ${ }^{44}$ Although many of these critics do not equate "institutional racism" with the intentional racism of individuals, the two are nevertheless often closely intertwined. Thus, scholars who discuss institutional racism generally assert that those who design and run institutions either fail to police discriminatory conduct by their subordinates and/or adopt facially neutral practices with at least the implicit knowledge (if not the express intent) that these practices will disadvantage blacks. ${ }^{45}$

Undoubtedly, there is merit in the institutional racism story. As study after study demonstrates, there are still a substantial number of whites who hold (consciously or unconsciously) discriminatory and/or stereotypical views about blacks. ${ }^{46}$ Scholars have put forward a plethora of theories to explain this continuing phenomenon, including, inter alia, that certain whites have an exogenous "taste" for discrimination, that whites employ biased stereotypes when evaluating blacks and whites,

43. See Schultz, supra note 7.

44. See, e.g., Gertrude Ezorsky, Racism and Justice: The Case for Affirmative ACTION 9-10 (1991) (arguing that when blacks are excluded from employment because they disproportionately do not have the specific training or experience necessary to perform the job, the resulting impact "is appropriately called racist impact").

45. See, e.g, James M. Jones, Prejudice and Racism 131 (1972) (discussing how individual intent contributes to institutional racism).

46. See, e.g., Paul Sniderman \& Thomas Piazza, The Scar of Race 64 (1993) (reporting that "substantial numbers of Americans are perfectly willing to express frankly negative characterizations of blacks" and that "racial stereotyping... [is] widely diffused, and ... far from uncommon"); Joe R. Feagin \& Melvin P. Sikes, Living with Racism: The Black MiddleCLASS EXPERIENCE 177-80 (1994) (describing customer and client prejudice against blacks); Ronald B. Mincy, The Urban Institute Audit Studies: Their Research and Policy Context, in CleAR AND Convincing Evidence: Measurement of Discrimination in America 165 (Michael Fix \& Raymond J. Struyk eds., 1993) (documenting instances in which employers treated black applicants substantially worse than equally qualified whites); HACKER, supra note 12, at 107-33 (documenting gaps between black and white employment levels in numerous fields of employment). Cf. Clark Nardinelli \& Curtis Simon, Customer Racial Discrimination in the Market for Memorabilia: The Case of Baseball, 105 Q.J. ECON. 575 (1990) (documenting race-based premium for baseball cards of white players). 
that whites judge individual blacks on the basis of the average statistical achievements of blacks as a group, that the preferences of customers and/or workplace culture impose additional costs on firms that hire and promote black workers, and that individual whites reward actions that reinforce the dominant status of whites as a group..$^{47}$ Regardless of the cause, however, unless we have reason to believe that corporate law firms are immune to attitudes and beliefs prevalent in the rest of society, it is likely that a non-trivial number of whites working in these institutions hold some of these views. ${ }^{48}$ As a result, one does not have to believe that overt racism is widespread in elite firms to conclude that these often subtle predispositions are sufficient to provide the grist for the dynamic described by institutional racism theories. Moreover, to the extent that some of the hiring and promotion policies followed by certain corporate firms bear little or no relation to the substantive qualifications of performing the job of a corporate lawyer, one can legitimately ask whether these practices actually serve a more invidious purpose.

Nevertheless, the institutional racism story, at least in the relatively straightforward terms in which it is usually presented, is at best incomplete. As a preliminary matter, this account is in tension with the widely accepted fact that overt racist attitudes are on the decline, particularly among highly educated and economically successful whites. ${ }^{49}$ Nor does

47. See, e.g., Gary S. Becker, The Economics of Discrimination, 43 (2nd ed. 1971) (claiming that discrimination is a result of a "taste" for avoiding association with people of other races); RICHARD A. POSNER, ECONOMIC ANALySIS OF LAW \$ 27.1 (3d ed. 1986) (suggesting that some whites wish not to associate with blacks); Richard McAdams, Cooperation and Conflict: The Economics of Group Status Production and Race Discrimination, 108 HARv. L. REv. 1003, 1044 (1995) (arguing that discrimination is a means for social groups to produce status for themselves); Charles R. Lawrence III, The Id, the Ego, and Equal Protection: Reckoning with Unconscious Racism, 39 STAN. L. Rev. 317 (1987) (connecting unconscious racism with the eultuml meaning of an allegedly racially discriminatory act); Edmund S. Phelps, The Statistical Theory of Racism and Sexism, 62 Am. ECoN. REv. 659 (1972) (describing statistical discrimination); Cass R. Sunstein, Why Markets Don't Stop Discrimination, 8 Soc. PHIL. \& POL'Y 22 (1991) (detailing how markets perpetuate discrimination).

48. See SNiderman \& Piazza, supra note 46, at 51 (reporting that "notwithstanding the role of societal institutions like formal education in reducing the prevalence of negative racial stereotypes, negative stereotypes of blacks character are widely diffused through contemporary American society"). We provide support for Sniderman and Piazza's conclusions in the context of elite law firms in Part III.

49. See Howard Schuman et al., Racial. Attitudes in America (1985) (reporting that virtually $100 \%$ of whites say that blacks and whites should have an equal chance to compcte for jobs); cf. Michael Selmi, Testing for Equality: Merit, Efficiency, and the Affirmative Action Debate, 42 UCLA L. REV. 1251, 1283-84 (1995) ("When the discrimination is subtle or unconscious, even a non-discriminating employer may not be able to identify and correct the resulting inefficiencies.... [S]tereotypes stem from the inability of individuals to internalize the social norms to which they openly ascribe so that while individuals proclaim they are not prejudiced their actions often indicate otherwise."). 
it explain why many firms have adopted voluntary affirmative action programs or taken other steps to increase the number of black lawyers. ${ }^{50}$

More fundamentally, the institutional racism story does not explain why firms neither change institutional practices in the face of evidence that they disproportionately burden blacks. Nor, in a world without de jure barriers to hiring blacks, can these theories explain why firms do not suffer a significant competitive disadvantage as a result of their failure to utilize black. workers who, although not meeting the "discriminatory" traditional criteria, are nevertheless fully competent to perform the job. In order to answer these questions, one must construct a richer account of the actual structure and operation of corporate law firms than the ones generally offered by institutional racism theorists. As we explain below, continuing racism-as well as a host of other attitudes, dispositions, and beliefs that tend to make it more difficult for whites and blacks to live and work together as equals-is an important component of this account. ${ }^{51}$ These individual attitudes, however, are at least in part the product of the manner in which firms hire, train, and monitor their employees. It is in the interplay between these structual factors and background assumptions about race and merit, we assert, that one must look for the answer to the question posed in this Article.

\section{Preaching to the Unconverted ${ }^{52}$}

Notwithstanding the evidence cited in the preceding Section, many academics and policymakers are skeptical about claims that race continues to play a significant role in impeding the progress of black Americans. Building on the indisputable evidence that outright racial prejudice is on the wane, these skeptics are inclined to attribute dispari-

50. See D'SouzA, supra note 35, at 291 (claiming that "racial preferences are now widespread in private sector job hiring"); Edward A. Adams, Survey Shows Diversity at Firms Still Lagging, N.Y. L.J., Mar. 29, 1995, at 1, 4.

5I. It is possible, of course, to classify all of these complex attitudes, dispositions, and beliefs as "racist." We reject this characterization on the ground that it conflates cause and effect in a manner that devalues the moral approbation that ought to accompany this charge. Racism is, and ought to remain, a serious charge applicable to those who consciously or unconsciously seek to devalue blacks because of the color of their skin. It should not be confused with the fact that in light of this country's racist past, virtually all Americans view each other through the prism of stereotypes and predispositions that are deeply connected to race. As we argue, these stereotypes and predispositions disadvantage eertain blacks in particular circumstances. We therefore focus attention on this historical legacy by identifying how these racialized attitudes intersect with institutional structures and practices in ways that reinforce existing inequalities. It is precisely because we believe that the majority of those who are participating in these structures are not racists that we believe that identifying this institutional dynamic might induce firms to change their behavior.

52. We are indebted to our friend and mentor Steve Shavell for emphasizing the need to frame our arguments in the language of those likely to be skeptical about both our description of the problem and the range of potential solutions. We hasten to add that by thanking Steve we do not mean to imply that he has been converted to our point of view. 
ties between blacks and whites to a lack of effort on the part of blacks. ${ }^{53}$ As a result, those who hold these views tend to oppose public and private efforts to redress racial imbalance on the grounds that these initiatives are both unnecessary, since blacks could solve their own problems by working harder to conform to traditional American values, and costly, because they will inevitably lower standards in a manner that decreases productivity and increases costs. ${ }^{54}$

The institutional analysis we propose speaks directly to these concerns. As we explain in Part $I$, we begin by accepting two central premises generally associated with conservative thought: that the practices and policies of elite corporate firms are a rational response to the market conditions within which these firms compete for labor and clients, and that individuals within firms (and those considering joining them) respond rationally to the incentives created by these institutional structures. $^{35}$ We hope to demonstrate, however, that these institutional structures are less directly connected to productivity than conservatives seem to believe, and that they create incentives for blacks that are contrary to the values and objectives that conservatives wish to further. Such a showing, we believe, should help to move the debate over black participation in elite sectors of the economy away from the current impass created by conclusory charges about whether racism is or is not widespread in contemporary American society. In order to do so, however, we must temporarily bracket the most contentious issue in this debate-affirmative action.

\section{Affirmative Action}

Any examination of black underrepresentation in corporate firms must inevitably confront the issue of affirmative action. This is true for two reasons. First, the level of affirmative action in law school admissions, law review memberships, firm hiring, and other relevant decisions affects the definition of the pool of qualified applicants. Second, judgments about this first issue are likely to be affected by normative and

53. See, e.g., SNIDERMAN \& PiAZzA, supra note 46 , at 41 (reporting that nearly $50 \%$ of whites surveyed agreed with the proposition that "if blacks would only try harder, they would be just as well off as whites").

54. See, e.g., D'Souza, supra note 35. See generally, Richard EPSTEIN, ForbiddeN Grounds: The Case Against Employment Discrimination Laws (1992) (arguing that antidiscrimination laws are both unfair and inefficient).

55. Indeed, by characterizing institutions and individuals as "rational" we risk alienating many of those who might otherwise be sympathetic to our basic conclusions but who are suspicious of "rational actor" models. Thus, a subsidiary aim of our analysis is to convince progressives that discussions of rationality and the market in the context of the microanalysis of institutions necd not deny the importance of culture, ideology, discourse, or emotion. See Rubin, supra note 10 . We sketch out this synthesis below. See infra notes 64-69 and accompanying text. We are grateful to Reva Siegel for pressing us on this point. 
factual claims about the fairness and/or efficacy of various affirmative action policies.

Judgements about both of these issues have become increasingly controversial. As to the first, perceptions vary widely about the degree to which schools, organizations, firms, and other relevant decision makers actually give some form of preference to black applicants, with some claiming that such preferences are pervasive while others assert that affirmative efforts to help blacks are much more apparent than real. ${ }^{56}$ Indeed, there is very little consensus on what constitutes "affirmative action" or whether policies that might fall under this rubric are properly considered as a "preference" for black applicants as opposed to a mechanism for giving blacks the same "preferences" as whites. ${ }^{57}$ This last debate merely underscores the deep divisions in the American public over whether affirmative action policies are a proper response to past and/or present racism or an illegitimate racial spoils system that inevitably ends up harming everyone including its intended beneficiaries. ${ }^{58}$

Given this construction the debate is irresolvable. There is very little reliable data on the actual extent of affirmative action (however defined) in corporate firms. Moreover, so long as this empirical question is tied to background assumptions about the extent to which blacks are disproportionately disadvantaged (or whites are unfairly advantaged) by other aspects of the system, the information that does exist is unlikely to sway those who hold different normative presuppositions.

In order to avoid this quagmire, we have chosen to break the issue down into its component parts. Thus, in Part II we examine the choices that firms and blacks make in a world in which firms have no specific policies designed to increase the number of black lawyers. ${ }^{59}$ We hold to

56. Compare D'SouzA, supra note 35, with Daniel G. Lugo, Don't Believe the Hype: Affirmative Action in Large Law Firms, 11 LAW \& INEQ. J. 615, 626 (1993).

57. See, e.g., lan Haney Lopez, White by Law: The Legal Construction of Race $157-$ 59 (1995) (describing the benefits that whites receive simply by not having to think of themselves in racialized terms); LeE Sigelman \& Susan Welch, Black Americans' Views of Racial INEQUAlity: ThE DREAM DeFerRed 134 (1991) (arguing that many "blacks and whites actually define affirmative action differently").

58. For examples of arguments in favor of affirmative action laws, see PATRICIA J. Williams, The AlChemy of RACE AND Rights 103 (1991) ("'Quotas,' 'preference,' 'reverse discrimination,' 'experienced,' and 'qualified' are con words.... As a society, we have yet to look carefully beneath them to see where the seeds of prejudice are truly hidden."); Alan Farnham, Holding Firm on Affirmative Action, Fortune, Mar. 13, 1989, at 87. For examples of arguments against affirmative action laws, see Stuart Taylor, Jr., Clinton and the Quota Game: Round One, LEG. TIMES, Dec. 28, 1992, at 23 (discussing firms labeled as discriminators, whose "only sin is hiring the best employees they can find"); D'SouzA, supra note 35, at 545 (arguing that affirmative action laws perpetuate a system of race-consciousness).

59. Notwithstanding this assumption, we do not rule out the possibility that individual whites within corporate firms might make special efforts to recruit or retain black lawyers. As with our treatment of discrimination in general, we simply assume that the attitudes of white corporate lawyers mirror the attitudes about race in American society as a whole. 
this assumption in Part III notwithstanding the fact that many of the firms we discuss have taken at least some affirmative steps to increase the number of black associates and partners. Given that these efforts should reduce the adverse effects on black lawyers that our model predicts, however, we feel justified in making this counterfactual assumption, particularly in the absence of reliable data on the extent and effectiveness of law firm affirmative action policies. In Part IV, we examine how affirmative action (along with a range of other legal, institutional, and public policies) might affect the strategic choices that our model predicts.

\section{III}

\section{The Model: Monitoring Among the Human Capitalists}

Scholars have offered a number of theories to explain the development and functioning of large law firms. The earliest emphasized that law firms are professional organizations, and sought to explain institutional practices in terms of norms such as competence, collegiality, and client service. ${ }^{60}$ Subsequent theorists criticized these early explanations by arguing that "professionalism" was merely the label under which law firms pursued their economic self-interest. ${ }^{61}$ The hard-edged economic determinism of these theories has in turn been criticized by those who point to aspects of firm structure or practice that cannot easily be explained by short-term (or even long-term) financial gain. ${ }^{62}$ Nevertheless, there is now an influential body of scholarship applying the tools of economic analysis to explain why lawyers as rational economic agents might choose to organize themselves into large law firms with the characteristics that we presently observe. ${ }^{63}$

60. The most famous such defense was offered by Erwin Smigel. See SMIGEL, supra note 13; Erwin Smigel, The Impact of Recruitment on the Organization of the Large Law Firm, 25 AM. Soc. REv. 56 (1960). Smigel's work was in the tradition of structural/functionalists, such as Talcott Parsons, who believed that institutional structures are driven by the functions they were designed to implement. See Robert L. Nelson \& David M. Trubek, Arenas of Professionalism: The Professional Ideologies of Lawyers in Context, in Lawyers' IDEALs/Lawyers' Practices: Transformations IN the American Legal Profession 177 (Robert L. Nelson et al. eds., 1992).

61. Richard Abel has been the leading exponent of this point of view. See ABEL, supra note 38; Richard L. Abel, Why Does the ABA Promulgate Ethical Rules?, 59 TEx. L. Rev. 639 (1981). Abel's work builds on the work of Magali Sarfatti Larson. See Magali S. LARSON, The RISE OF Professionalism: A Sociological ANalysis (1977).

62. See, e.g., Robert W. Gordon, The Independence of Lawyers, 68 B.U. L. REv. 1 (1988) (discussing professional independence and the social factors that affect it); William H. Simon, Babbit v. Brandeis: The Decline of the Professional Ideal, 37 STAN. L. REv. 565 (1985) (positing professional idealism as an explanation for firm behavior).

63. See, e.g., Galanter \& Palay, supra note 24; Ronald J. Gilson \& Robert H. Mnookin, Sharing Among the Human Capitalists: An Economic Inquiry Into the Corporate Law Firm and How Partners Split Profits, 37 STAN. L. REv. 313 (1985) [hereinafter Gilson \& Mnookin, Human Capitalists]; Ronald J. Gilson \& Robert H. Mnookin, Coming of Age in a Corporate Law Firm: The Economics of Associate Career Patterns, 41 STAN. L. REv. 567 (1989) [hereinafter Gilson \& 
Our model builds on these efforts, but in a way that incorporates the importance of professional ideology, social capital, and inequality captured by the critics of economic determinism. ${ }^{64}$ Like those who have applied economic theory to understand professional practices, we assume that lawyers, law firms, and clients are rational actors who seek to maximize their own interests. It is important, however, to stress the limits of this standard economic assumption. First, building on the work of Herbert Simon, we assume that rationality is bounded by the information an actor receives and by that actor's ability to understand and convey this information to others. ${ }^{65}$ Second, the "interests" these market participants pursue are primarily - but not exclusively-monetary. For example, individual lawyers and firms compete for relative status or prestige in ways that may or may not be reducible to monetary gain. ${ }^{66}$ Third, as Robert Nelson's study of corporate law firms in Chicago underscores, even when these entities wish to maximize their economic interests, professional ideology and culture may restrict their ability to perceive and or implement institutional policies likely to achieve these goals efficiently. ${ }^{67}$ Similarly, "the social capital that lawyers bring to

Mnookin, Coming of Age]; S.S. Samuelson \& L. Fahey, Strategic Planning for Law Firms: The Application of Management Theory, 52 U. PITT. L. REv. 435 (1991); S.S. Samuelson, The Organizational Structure of Law Firms: Lessons From Management Theory, 51 OHю ST. L.J. 645 (1990); S.S. Samuelson \& L.J. Jaffe, A Statistical Analysis of Law Firm Profitability, 70 B.U. L. REv. 185 (1990). This literature is part of a wider trend toward applying economic principles to the study of the legal profession in particular and law and legal institutions more generally. See, e.g., Louis Kaplow \& Stephen Shavell, Legal Advice About Information to Present in Litigation: Its Effects and Social Desirability, 102 HaRv. L. REv. 565 (1989); Stephen McG. Bundy \& Einer R. Elhauge, Do Lawyers Improve the Adversary System? A General Theory of Litigation Advice and Its Regulation, 79 CALIF. L. Rev. 313 (1991).

64. See Rubin, supra note 10, at 1424 (arguing for a new methodology that would "merge the 'hard' social science of economics with the 'soft' social sciences of organization theory and political analysis").

65. See Herbert A. Simon, Administrative Behavior xxiv-xxxvii (2d ed. 1961). For a discussion of the importanee of this concept, see Rubin, supra note 10, at 1414, 1426-27.

66. For example, in their study of the Chicago bar, Heinz and Laumann report both that lawyers value collective projects to improve the status of the profession and that the perceived status of a given legal field affects a lawyer's decision to practice in that area. See JoHN P. HEINZ \& Edward O. Laumann, Chicago Lawyers: The Social Structure of the Bar 247 (1982) (reporting that $87.2 \%$ of the Chicago lawyers responding to a survey rated enhancing the status of the profession as very important); id. at $135-36$ (noting that the prestige attached to a given field is likely to affect lawyer career choices). Moreover, "the income that a lawyer receives from his practice is not significantly associated with the prestige of his field." Id. at 134; see also JEROLD S. AUERBACH, Unequal Justice: Lawyers and Social Change in Modern America 93-96 (1976) (arguing that nineteenth-century lawyers sought to exclude recent immigrants from the bar primarily for status reasons rather than because allowing these new entrants into the profession would harm the economic interests of the elite bar). See also McAdams, supra note 47, (arguing that discrimination is a mcans for the discriminating group to produce status for its members). But see Richard A. Epstein, The Status Production Sideshow: Why the Antidiscrimination Laws Are Still a Mistake, 108 HARv. L. Rev. 1085 (1995) (responding to McAdams).

67. See NELSON, supra note 24, at 4, 10 (arguing that professional norms of independence and collegiality inhibit the development of rational bureaucratic decision making). Lincoln Caplan 
efforts to gain prominence in a particular field, for example their family background or cosmopolitan connections, affects significantly the success or failure of the efforts."68

Finally, to say that lawyers and firms are rational does not mean that passion, prejudice, and taste have no bearing on decisionmaking. As we develop below, stereotypes, predispositions, and other related background assumptions and tastes play an important role in lawyer and firm decisionmaking. We also assume, however, that those who have these beliefs respond rationally (as we have now defined this term) to evidence that either confirms or denies these predispositions. ${ }^{69}$

In this Part, we explain why policies and practices common among elite corporate law firms are a rational response to the market conditions these firms confront. Section A presents a general theory to explain how firms that pay high wages and employ complex hierarchical institutional practices insulate themselves from the economic consequences of practices that unfairly disadvantage black workers. Section B applies this general theory to law firms.

chronicles an example that demonstrates both the power and the limits of professional ideology when it conflicts with economic gain. According to, Caplan, many established New York law firms were slow to get into the takeover business in part because the partners who ran these firms eonsidered hostile bids unethical and the lawyers who pursued them unprofessional. See LincoLN CAPLAN, SKADDEN: Power, MONEY, AND THE RiSE OF A LEGAL EMPIRE 52 (1993). As the established firms watched Skadden grow rich and powerful from this work, however, scruples faded, and the large firms rushed in to take advantage of this lucrative new area of practice. See id. at 207-27. Significantly, as cognitive dissonance theory predicts, these firms reinterpreted their understanding of professionalism to accommodate this new form of practice. See id. at 216 . For a discussion of how lawyers reshape ideas about professionalism to accommodate changes in the economics of practice, see Austin Sarat, ldeologies of Professionalism, Conflict and Change (1992).

68. Yves Dezaly \& Bryant Garth, Constructing an International Legal Order and Transforming the State: Human Rights, Constitutionalism, and the Legalization of Trade 15 (1995) (unpublished manuscript, on file with author).

69. In this respect, our analysis differs from those who assert that because racism is often "unconscious" (meaning that actors are unaware of the fact that they are influenced by racial stereotypes) it cannot be corrected by market forces. See Selmi, supra note 49, at 1288-89 (suggesting that market forces will work less efficiently when unconscious racism leads an "employer [to] forego[ profits unconsciously"). Professor Selmi's article builds on the work of Professor Charles Lawrence. See Lawrence, supra note 47, (proposing a test for judicial recognition of raee-based behavior that considers unconseious racism). While we agree with Sclmi that unconscious stereotyping often plays a central role in the differential treatment of black and white applicants, and that these beliefs are often resistant to falsification precisely because they are unconscious, actors who do not hold consciously racist beliefs still have an incentive to respond to evidence tending to show that their preconceptions are false when it is in their self-interest to do so. The problem, is that in many circumstances "market experience [will] not teach sellers that their preconceptions are false" because the actors have struetured their activity in such a way as to insulate themselves from the economic consequences of their discriminatory conduct. lan Ayres, Fair Driving: Gender and Race Discrimination in Retail Car Negotiations, 104 HaRv. L. REv. 817, 850 (1991). 


\section{A. Discrimination in High-Level Jobs ${ }^{70}$}

For more than four decades, neo-classical economists have posed a trenchant query to those who advocate governmental or private intervention to prevent employment discrimination: If there are no meaningful differences between blacks and whites, as anti-discrimination advocates unanimously assert, why won't discriminating employers be driven out of business by competitors who cut labor costs by hiring qualified blacks at lower wages?"1 This challenge is based on two standard assumptions about labor markets and firms. First, those who claim that competition will eventually drive out discriminating firms assume that employers set wages to equal an employee's marginal productivity and that wages fall until there are no longer any qualified workers to fill the demand (the "market-clearing wage" hypothesis). ${ }^{2}$ Second, they assume that all firms have perfect information about the quality of potential workers and that decisions about hiring and firing are costless (the "perfect information" hypothesis). ${ }^{73}$

Even if one accepts these two assumptions, the conclusion that discriminating firms will inevitably be driven from the market is far from certain. ${ }^{74}$ In recent years, however, a growing chorus of economists and sociologists have persuasively argued that both the market-clearing wage and the perfect-information hypotheses fail adequately to explain the ways in which many sectors of the labor market actually operate. ${ }^{75}$ These theorists argue that in certain instances, firms will find it efficient to pay workers a higher than market-clearing wage and to employ complex hierarchical employment structures in order to reduce the cost of acquiring information about worker performance. By artificially creating a large pool of "unemployed"76 workers who are both willing and

70. By "discrimination" we simply mean a regime in which employers, for whatever reason, prefer average whites to average blacks. In keeping with the assumption outlined above, we do not assume that this phenomenon is the result of employers holding racist views about blacks (as we have defined that term). See supra note 51.

71. This theory was first developed by Gary Becker in the 1950s. See BECKER, supra note 41, at $40-43$.

72. See Charny \& Gulati, supra note 9 , at 4 .

73. Id.

74. For thoughtful criticism of these claims, see John J. Donohue III, Is Title VII Efficient?, 134 U. PA. L. Rev. 1411 (1986); Cass R. Sunstein, The Anticaste Principle, 92 Mrch. L. Rev. 2410 (1994).

75. For a general critique of the market clearing wage hypothesis, see, e.g., Chamy and Gulati, supra note 9, at 11-14; EfFicrency WAGE MOdels of THE LABOR MARKET (George A. Akerlof \& Janet L. Yellen eds., 1986); Robert M. Solow, The Labor Market as a Social Institution 28-33 (1990); ANDREW WeISS, EFFICIENCY WAGES: MOdels OF UNEMPLOYMENT, LAyOFFS, AND WAGE Dispersion (1990). For a powerful critique of the perfect information hypothesis in the context of labor markets, see John J. Donohue IIl, Employment Discrimination Law in Perspective: Three Concepts of Equality, $92 \mathrm{Mrch}$. L. REv. 2583 (1994) (contrasting labor markets with capital markets).

76. By "unemployed" we simply mean that there are workers who are willing to work for the high salaries being offered even if they currently have other, lower-paying jobs. 
competent to perform the job, firms that utilize one or both of these strategies can partially shield themselves from the kind of market pressures that neo-classical theorists assert will drive out discrimination.

In an Article written with Professor David Charny, one of us has argued that firms will find high wages and other hierarchical institutional structures particularly attractive in circumstances in which the subjective nature of performance renders monitoring and evaluating worker quality expensive. ${ }^{7}$ The following four Sections briefly summarize and expand this argument and its implications for the employment prospects of black workers.

\section{Subjectivity and Monitoring}

Firms pay wages in order to induce employees to perform their jobs competently and efficiently. Once a worker is hired, however, there is always the danger that he or she will shirk by working either less hard or competently. The standard response to this danger is for firms to monitor employee performance directly and to discharge those workers who are not performing effectively.

Direct monitoring, however, is expensive. Employers must divert resources from revenue-generating activities into detection and enforcement. This is particularly true when performance cannot be evaluated by reference to easily observable objective criteria such as outputs. In circumstances in which quality judgments depend on a complex evaluation of an employee's technical competence, thoroughness, and judgment (in addition to results), a firm would have to retrace a good deal of the employee's actual decision making process before it could reach an accurate assessment about performance.

Firms seek to reduce this burden by offering employees additional incentives to work hard that do not depend exclusively on direct monitoring. ${ }^{78}$ These alternatives fall into two general categories: high wages and tournaments.

\section{When lt's Cheaper to Overpay}

One way to induce effort without monitoring is to pay employees a higher wage than they could receive elsewhere in the market. This wage premium has two effects that collectively tend to lower monitoring costs. First, by offering a higher than market-clearing wage, firms generate a large pool of qualified applicants from which to hire. ${ }^{79}$ This reduces

77. See Charny \& Gulati, supra note 9 .

78. No firm will be able to avoid direct monitoring altogether, since without it employees would face no risk that their shirking will be detected. At best, therefore, these alternative strategies only supplement direct enforcement. See id. at, $16 \mathrm{n} .52$.

79. Id. at 15-16. Higher wages also attract a certain number of unqualified applicants. However, since even qualified applicants face long odds of actualiy securing these coveted positions 
search costs and places the burden on applicants to differentiate themselves from the rest of the pool. Second, once a worker is hired, she has an incentive to work hard since she knows that if she is fired for shirking, she cannot obtain a similar salary elsewhere and that there are many "unemployed" workers who would gladly take her place. ${ }^{80}$ The net result is that firms that employ a high-wage strategy will have an easier time finding qualified workers and will have to spend fewer resources to ensure that those hired are performing their jobs efficiently.

Moreover, once one firm adopts a high-wage strategy, competitors will feel strong pressure to follow suit. Firms that seek to cut costs by refusing to pay the wage premium run the risk of losing "good" workers to firms that do while simultaneously attracting "bad" workers who cannot currently get jobs at the higher wage. ${ }^{81}$ High wages therefore tend to be inelastic to downward market pressures.

\section{Tournament Theory}

Firms also seek to induce effort by promising employees a reward (commonly either a cash bonus or a lucrative promotion) if they can credibly signal that they have successfully performed their jobs over a specified period of time. In such firms, workers compete against each other in a "tournament" that rewards those who have made the greatest contributions to the firm. ${ }^{82}$ Shirking, therefore, is costly to the employee because it reduces her chance of receiving the reward. Indeed, when properly designed (that is, when the reward is sufficiently large and the chances of obtaining it are reasonable-although by no means

(a product of the high wage exerting downward pressure on demand), unqualified applicants will find it relatively inefficient to spend much time seeking high wage jobs.

80. This should also reduce costs associated with turnover since workers are less likely to leave these high paying, and therefore scarce, jobs voluntarily.

81. See Charny and Gulati, at 12-13. Firms can attempt to avoid or reduce this effect by paying some workers more than others or by signaling that they offer workers additional benefits (such as working conditions, promotions, status) that more than offset the decrease in salary. There are, however, barriers to implementing both of these strategies. In order to pay differential wages, firms must be able reliably to distinguish good workers from bad ones. When quality assessments are subjective, such distinctions will always be expensive (for the same reasons that monitoring is expensive) and may, for reasons we develop in our account of the large law firm, be impossible. Moreover, the more arbitrary these judgments seem, the more pay differences run the risk of decreasing employee morale. Finally, just as employees will have a difficult time assessing the faimess of case-by-case wage differentials, they will also be suspicious of promises of better working conditions, promotion rates, or other non-monetary benefits. In each of these areas, firms have an incentive (albeit tempered by reputational concems) to promise more than they deliver or to act opportunistically after the employee has committed to the firm.

82. See id. at 13-14. For a general overview of toumament theory, see, e.g., James M. Malcolmson, Work Incentives, Hierarchy, and Internal Labor Markets, 92 J. PoL. EcoN. 486 (1984); Lome Carmichael, Firm-Specific Human Capital and Promotion Ladders, 14 BELL J. EcoN. 251 (1983); Edward P. Lazear \& Sherwin Rosen, Rank-Order Tournaments as Optimum Labor Contracts, 89 J. POL. ECON. 841 (1981). 
guaranteed), employees can be motivated to expend efforts that go beyond what could be expected in a world in which monitoring was both perfect and costless. ${ }^{83}$

Firms can further lower their monitoring costs by structuring the tournament in ways that give employees incentives to contribute monitoring resources to the firm. For example, consider a tournament in which a senior employee's possibility of obtaining the reward (for example, promotion to partnership) depends in part upon the work of that employee's juniors. Under these circumstances, experienced employees have an incentive to monitor their subordinates more carefully than they would otherwise. Firms thus have an incentive to create a pyramid structure in which a relatively small number of experienced employees are responsible for monitoring the performance of a larger number of junior workers, who are themselves motivated to work hard by the prospect of becoming senior employees who are then eligible for the reward. ${ }^{84}$

\section{4. "Efficient" Discrimination}

Firms that employ high wages, tournaments, or some combination thereof, to induce worker effort face reduced market pressures to detect and sanction employment decisions that either penalize blacks or favor whites. This is true for two reasons.

First, assuming that firms face a normal bell-shaped distribution of worker talent (that is, a small number of "superstars" and "unacceptable" workers at either end with the majority of candidates clustered together in the "average" range), they should be relatively indifferent as to which average candidates are hired. ${ }^{85}$ Since quality is subjective and therefore difficult to evaluate, the signals applicants use to demonstrate their merit (for example, educational credentials, recommendations, work experience) will be "noisier" (that is, less reliable predictors of actual quality) the closer one gets to the mean. Although a thorough investigation of potential employees (for example, an indepth interview, reading sample work product, or an apprenticeship period) might reveal whether an applicant's signals are reliable, firms that employ high wages and tournaments to save on monitoring costs have little incentive to invest in this kind of cross-checking. As a result, can-

83. For example, in a world where firms only use direct monitoring to induce effort, employees have little incentive to perform above whatever minimum level the firm establishes for "good" work. In a firm that employs a toumament to save on monitoring costs, even "good" work may go unnoticed. Consequently, if getting noticed is a necessary condition for winning the toumament, employees have an incentive to do better than good work.

84. As we explain below, this is not the only incentive for firms to create a pyramidal structure. See infra Part II.B.2.b.

85. See Charney and Gulati, supra note 9, at 14-17. 
didates in the average range appear indistinguishable from the firm's perspective. Because the firm pays high wages, there will be a large number of average candidates available.

As a result, the firm has little reason to investigate whether those responsible for hiring systematically prefer average whites to average blacks. By definition, the firm does not lose productivity as a result of such discrimination. Average workers are merely being substituted for average workers. Furthermore, because of the inflexibility of wages, the firm will not be placed at a competitive disadvantage vis-à-vis those firms who do not discriminate since these latter employers will find it difficult to hire blacks at reduced wages, thereby cutting their costs below those of firms where average whites are favored. ${ }^{86}$ This effect is exacerbated in firms that also utilize a tournament in order to separate those who are truly outstanding from the many who are merely competent. Because these firms know that they will be able to collect a large amount of relatively reliable information about employee performance before they promote the small number of tournament winners to senior positions, these organizations have even less incentive to make accurate distinctions among average workers at the hiring stage.

Second, because black applicants know that they face reduced opportunities-that is, that they will lose out to average whites unless they can clearly signal themselves to be superstars-they have an incentive to invest in human capital strategies that, paradoxically, will on average decrease their chances for success. ${ }^{87}$ As an initial matter, since black applicants face higher entry barriers, they have an increased incentive to invest in acquiring the kind of signals that employers look to when deciding which candidates are outstanding. To the extent that these sig-

86. See id. at 18. As the text implies, firms will suffer both productivity and competitive losses if they hire average whites over superstar blacks. This simple economic reality helps account for the widely held belief that blacks with outstanding credentials receive many offers from elite employers in business and the professions. For reasons that we set out below, however, the fact that a black superstar gets hired does not mean, that he or she will be accorded the same opportunities and perquisites that white superstars receive. This, in turn, helps to explain wby black superstars win toumaments in smaller numbers than their white counterparts. See infra Part III.B.

87. See id. at 19-24. Once again, we stress that blacks are not the only ones likely to choose one of these strategies. Because average whites also have a difficult time securing jobs in firms that employ high wages and tournaments to reduce monitoring costs, they too have an incentive to overinvest in the signals necessary to obtain the job (as opposed to actual job skills) and to pursue the kind of low investment or high investment strategies described in the text. Nevertheless, since average blacks face the additional barriers described above, we should expect that they will be even more likely to follow one of these paths-and to do so in a manner that exaggerates the dangers involved-than their white peers. Of course, in those situations where certain whites also face additional barriers, (for example, women, openly gay whites, or wbites from lower socio-economic backgrounds), we might see similar skewing effects. Given our skepticism about whether the experiences of the members of one disadvantaged group are automatically transferable to other disadvantaged groups, we venture no opinion about whether the skewing effect would in fact be the same. 
nals directly measure skills that are actually necessary to perform the job effectively, this extra incentive performs a positive function by increasing black investment in human capital. In many cases, however, firms value a particular signal (for example, obtaining a high school diploma) because they view it as a surrogate for some difficult to observe personal quality (for example, hard work or perseverance) rather than because the signal actually represents a valuable job skill. ${ }^{88}$ Moreover, where firms rely on high wages and tournaments because of the difficulty of evaluating and monitoring highly subjective job performance, the link between the signals these employers are likely to look for and either actual job skills or the personal qualities of good workers is unlikely to be tight enough to produce only beneficial effects on the investment decisions of black workers. Instead, firms are likely to prefer less accurate but easily observable signals over ones that are more difficult to observe or measure, but are ultimately better correlated with future job performance, on the ground that the gap between expected quality (as measured by these less costly signals) and actual quality can be sorted out in the course of the tournament. As a result, investing heavily in obtaining these signals can end up damaging a black employee's long-term prospects. Although black candidates who invest disproportionately in signals may increase their chances of being hired, if we make the plausible assumptions that there is at least some tradeoff between investing in signals and investing in skills (if for no other reason than the finite nature of time), and that beginning work with skills is positively correlated with success on the job, these workers may also have a decreased chance of actually winning the tournament.

The incentives that push the investment decisions of black employees in directions that decrease their chances for success are even more prevalent once the employment relationship begins. Given that the same social forces that tend to lead whites to prefer average whites over average blacks are likely to continue inside firms, those blacks who manage to secure one of these coveted positions must decide how to react to these diminished opportunities. Some black workers may seek to minimize the adverse consequences of their employers' diminished expectations by avoiding situations where they believe that their competence might be drawn into question. Others will take the opposite tack and invest heavily in their careers at the firm by taking on difficult

88. Andrew Weiss describes this "sorting process" as follows: "In sorting models, schooling is correlated with differences among workers that were present before the schooling choices were made; furms make inferences about these productivity differences from schooling choices, and students respond to this inference process by going to school longer." Andrew Weiss, Human Capital vs. Signaling Explanations of Wages, 9 J. ECON. PERSP. I33, 134 (1995). 
or risky projects that, if successful, might induce firm leaders to view them as superstars instead of merely as average.

Both strategies decrease an average black worker's chances for success at the firm. The futility of the first choice is clear: although those pursuing a low-risk strategy may manage to avoid making the kinds of mistakes that will lead their employers to view them as unacceptable (and therefore candidates for being fired immediately), they are also unlikely to win a tournament in which others are investing heavily in firm-specific skills. At the same time, average black workers who pursue high-risk strategies by taking on more than their share of difficult or risky work assignments-assignments that would be difficult even for those with superstar abilities-run a substantial risk of being downgraded in the estimation of their employers if they fail to pull all of these projects off successfully.

Given this dynamic, discrimination will be self-perpetuating in firms that employ high wages, tournaments, or some combination thereof to reduce monitoring costs. ${ }^{89}$ The next section argues that this dynamic helps to explain the current structure of large law firms.

\section{B. Making Elite Law Firms}

Elite firms depend for their economic survival upon delivering high-quality legal services at acceptable prices. As a result, a firm's most important asset is the accumulated human capital of its lawyers. ${ }^{90}$ Firms therefore have strong incentives to seek out lawyers who will preserve and enhance the firm's reputation and to ensure that partners and associates in fact fulfill this promise throughout their tenure with the firm.

This basic economic truth lies at the core of the standard claim, recited like a mantra by every law firm during recruiting season, that its hiring and promotion practices are solely designed to produce the "best" lawyers. In this Section we argue that these familiar claims are ultimately misleading. Firms do have an incentive to hire and promote the "best" workers, but only insofar as the cost of evaluating and monitoring worker quality does not exceed the returns from selecting marginally better workers. Hence, the resources firms are likely to devote to making distinctions among workers vary with both the cost of reaching reliable quality determinations and the expected benefit to the firm of more accurate matches between employees and jobs. As we shall see, elite law firms have developed institutional practices with re-

89. See Charney and Gulati, supra note 9, at 23.

90. See Gilson \& Mnookin, Human Capitalists, supra note 63, at 324-27 (discussing the "critical role of human capital"); see also Peter D. Sherer, Leveraging Human Assets in Law Firms: Human Capital Structures and Organizational Capabilities, 48 Indus. \& LAB. REL. Rev. 671 (1995). 
spect to both of these issues that reduce their need to invest substantial resources in distinguishing among average workers at crucial stages in the employment process.

\section{Good Lawyers are Made, Not Born}

In the previous Section, we explained why firms gravitate towards high wages and/or tournaments in circumstances where the subjectivity of quality assessments renders monitoring both difficult and expensive. Large law firms find themselves in this position due to two related characteristics of lawyering. First, legal work contains a core element of discretionary judgment, which is the product of both contingent external factors and the lawyer's own character, insight, and experience. Second, partly as a result of this core discretionary element, good lawyering is a practice that ultimately cannot be reduced to principles or rules that can be taught in the classroom. These two related characteristics render judgments about a lawyer's quality inherently subjective and provisional.

Lawyers have long asserted that one of the most important distinctions between their "calling" and other "occupations" is the link between lawyering and judgment."1 Although lawyers frequently exaggerate both the uniqueness of legal judgments and the implications of recognizing that lawyers inevitably exercise discretion, ${ }^{92}$ the claim that good judgment lies at the core of good lawyering rests on solid ground.

Good judgment in this context derives from, but ultimately transcends, specialized knowledge and technical expertise. In order to render sound advice to clients or make persuasive arguments in court, a lawyer must have a firm command of the relevant substantive and procedural doctrines. But an effective lawyer must also be a good judge of character, a quick and accurate calculator of costs and benefits, an empathetic listener, and a thorough, balanced, and calm deliberator who nevertheless does not lose sight of the important role that passion plays

91. See anthony T. Kronman, The Lost Lawyer: Failing ideals of the Legal Profession 3 (1993) (describing "judgment" as the core of the lawyer-statesman ideal of professional practice). Indeed, for many, this ineluctable element of discretionary judgment is a defining feature of professionalism generally. See, e.g., AMERICAN BAR Association, "IN THE Spirit of A Public Service..." (1986) (endorsing sociologist Eliot Friedson's definition of professionalism as, inter alia, involving a practice that "requires substantial intellcctual training and the use of complex judgments").

92. One of us has written about this subject extensively. See David B. Wilkins, Who Should Regulate Lawyers?, 105 HARv. L. REv. 799, 853-73 (1992) (discussing the misuse of arguments about "independent judgment" in the debate over self-regulation); David B. Wilkins, Practical Wisdom for Practicing Lawyers: Separating Ideals from Ideology in Legal Ethics, I08 HARV. L. REV 458, 468-472 (1994) (discussing how claims that lawyers are especially gifted at making certain kinds of judgments have been used to justify lawyer paternalism). 
in human affairs. ${ }^{93}$ In the world of elite law practice, she must also be a team player, a salesperson, and a manager of complex personalities, events, and institutions. ${ }^{94}$ Indeed, given the indeterminacy of many areas of the law, even technical legal competence involves an important element of discretionary judgment. ${ }^{95}$

Moreover, lawyers develop virtually all of these relevant qualities, including technical expertise, on the job. Lawyers have always referred to what they do as the "practice" of law. As with claims about the importance of professional judgment, the profession has frequently used this standard assertion to advance its own ends. ${ }^{96}$ In addition, however, the word also captures how lawyers generally believe good legal skills are cultivated-in practice. Although law schools now make more of an effort to be comprehensive, including offering students a variety of clinical courses in which they actually perform legal work, the gap between what law schools teach and what practicing lawyers need to know is arguably as wide as it has ever been. ${ }^{97}$

Together, these two features of good lawyering make it difficult for law firms to reach accurate judgments about the qualifications of potential recruits, to train these new lawyers once they are hired, and to ensure that they are performing competently. At the recruiting stage, because most of the qualities of a good lawyer (including the ability to reach

93. See Kronman, supra note 91, at 2 (arguing that an outstanding lawyer is "a person of good judgment, and not just an expert in the law"); CAPLAN, supra note 67, at 3 (reporting that Skadden founder and mega-dealmaker Joe Flom's partners are most impressed by "the power of his brain and by his large quota of the vague but bankable resource that lawyers call good judgment"); Angela $P$. Harris \& Marjorie M. Shultz, "A(nother) Critique of Pure Reason": Toward Civic Virtue in Legal Education, 45 STAN. L. REv. 1773 (1993) (discussing the importance of emotion in legal argument).

94. See Gilson \& Mnookin, Coming of Age, supra note 63, at 572 (arguing that "subjective personal characteristics-for example, cooperativeness, maturity, the ability to gain respect of existing clients and to recruit new ones-... traditionally have been important to the partnership decision"); Mary Ann Galante, Firms Finding More Value in Marketing, NAT'L L.J., Nov. 18, 1985, at 28-29 (arguing that successful lawyers must learn to deal effectively with the media and public relations personnel).

95. See David B. Wilkins, Legal Realism for Lawyers, 104 HaRv. L. Rev. 468, $478-99$ (1990). For an argument that connects indeterminacy to discretionary judgment, see William H. Simon, Ethical Discretion in Lawyering, 101 HARv. L. Rev. 1083 (1988).

96. See generally Charles W. Wolfram, MODERN Legal Ethics 76 (1986) (noting that lawyers seek to distinguish the practice of law from other forms of moral political and economic argument as a way of enhancing their own power); Deborah L. Rhode, Policing the Professional Monopoly: A Constitutional and Empirical Analysis of Unauthorized Practice Prohibitions, 34 STAN. L. Rev. 1 (1981) (arguing that claims about the inherent distinctiveness of the practice of law are used to support restrictive unauthorized practice rules).

97. See Task force on Law Schools and the Profession: Narrowing the Gap, Section of Legal Education and admissions to the Bar, american Bar association, Legal Education and Professional Development-an Educational Continuum (Robert MacCrate ed., 1992) [hereinafter MACCRATE REPORT]. See also David Luban \& Michael Millemann, Good Judgment: Ethics Teaching in Dark Times, 9 Geo. J. LEGAL ETHICs 31 (1995) (arguing that the kind of judgment that lawyers need to cultivate is best taught through trial and error and by imitation). 
sound discretionary judgments) are learned on the job, the firm must rely on predictors of future success as opposed to a record of demonstrated ability. The most visible signals about the potential quality of particular applicants (i.e., law school grades and other traditional academic honors), however, are not strongly correlated with either substantive lawyering skills or the personal qualities that it takes to be successful in the practice of law.

Two aspects of the grading process diminish its predictive capacity with respect to substantive lawyering skills. First, many of the substantive areas in which elite firm lawyers work are either not taught in law school at all or are covered only in introductory survey courses that spend relatively little time on the kind of cutting edge legal issues that increasingly occupy corporate lawyers. ${ }^{98}$ Second, even with respect to those fundamental skills taught in the standard law school curriculum, such as "thinking like a lawyer" and the basic architecture of the legal system, the predictive value of grades is distorted by the peculiar characteristics of the law school examination process.99 ${ }^{9}$ Although grades may work better as a proxy for personal qualities that are plausibly connected to success in law, such as intelligence, hard work, perseverance, or perhaps aggressiveness, even this signal is noisy. A certain percentage of students who lack some or all of these qualities nevertheless get good grades. Other equally valuable talents (such as the ability to work well with others) may be inversely correlated with success in law school. ${ }^{100}$ As a result of all of these factors, "[e]ven law teachers acknowledge that a student's performance in law school is a very noisy signal of her long-term performance as a lawyer."101 This assessment is confirmed by empirical research finding little or no correlation between

98. See Graham C. Lilly, Law School Without Lawyers? Winds of Change in Legal Education, 81 VA. L. Rev. 142I, 1450 (1995) (describing "alienation between academics and practicing professionals"); Roger Parloff, For the Record: Dean Anthony Kronman, AM. LAw., Jan.-Feb. 1996, at 85,89 (noting the low correlation between much of legal education and the tasks one faces at a law firm).

99. As Michael Selmi demonstrates, even tests that are aimed precisely at predicting future performance (which law school grades are not) are often unreliable due to underinclusiveness (the test's failure to capture all of the relevant criteria responsible for success at the subsequent task), overinclusiveness (testing for qualities such as risk taking that are unrelated to future performance), and measurement errors (individuals will score differently on the same test if taken at different times). See Selmi, supra note 49, at 1261-76. As a result, most employment tests explain less than $15 \%$ of the variance in future performance. The Law School Admissions Test (LSAT), for example, explains only about $10 \%$ of the variance in first-year grades among test-takers (its intended target). See id. at 1263-64. There is little reason to expect that law school grades, which are not specifically designed to measure future performance as a lawyer, would do any better.

100. See Richard C. Reuben, The Lawyer Turning Peacemaker, A.B.A. Journal, 54-62 (August 1996) (criticizing law schools for discouraging cooperation and concilliation).

101. Gilson \& Mnookin, Coming of Age, supra note 63, at 572 n. 16. 
legal education or success in law school and partner income. ${ }^{102} \mathrm{Al}$ though firms could improve the quality of their predictive judgments by looking behind a candidate's grades and other paper credentials, for example by reviewing a candidate's work product or talking to references, each additional step will inevitably increase the cost of recruiting. ${ }^{103}$

The fact that law is a practice that must be learned on the job also increases a firm's training costs. Traditionally, firms taught young lawyers by gradually allowing them to take increasing amounts of responsibility on a broad array of projects under the direction of senior lawyers. This apprenticeship model, however, is expensive because it takes senior lawyers away from revenue-generating activities. ${ }^{104}$

Finally, given the importance of discretionary judgment to assessing the quality of a lawyer's work, results are not an accurate measure of shirking. In many instances, the end result of the representation-for example, the fact that a motion was lost or a deal completed-is a very imperfect measure of the quality of the work that went into producing this result. ${ }^{105}$ Even easily measurable inputs such as the time that it takes a lawyer to accomplish a given task can be misleading in the absence of further investigation. ${ }^{106}$ Therefore, in order to make accurate judgments

102. See James B. Rebitzer \& Lowell J. Taylor, Efficiency Wages and Employment Rents: The Employer-Size Wage Effect in the Job Market for Lawyers, 13 J. LAB. ECoN. 678, 690 (1995) (reporting that in their analysis of partner income, variables corresponding to law school prestige, law review membership, and top law school grades "are not statistically significant at the 5\% level"); see also Lugo, supra note 56, at 624 (claiming that many law firm partners were neither former law review members nor top percentage graduates).

103. This is particularly true with respect to those personal qualities that are not strongly correlated with success in law school. See Brendan O'Flaherty \& Aloysius Siow, Up-or-Out Rules in the Market for Lawyers, 13 J. LAB. EcoN. 709,712 \& n.10 (1995) (noting that firms do not consider a potential associate's ability to generate business, get along with colleagues, and supervise employees because "it is probably difficult to distinguish between new law school graduates on the basis of these skills").

104. See Richard N. Feferman, Bullding Your Firm with Associates: A Guide for Hiring ANd Managing New Atrorneys 55-56 (1988) (acknowledging that time spent training associates is generally not billable to clients).

105. This is not to suggest, of course, that results have no probative value or that a pattern of results (e.g., a lawyer who loses every case) might not be even more probative.

106. Thus, a recent commentator's claim that " $[t]$ he view that attorneys are difficult to monitor breaks down under closer analysis" is only half right. See Kevin A. Kordana, Note, Law Firms and Associate Careers: Toumament Theory Versus the Production-Imperative Model, 104 YALE LJ. 1907, 1914 (1995). Kordana correctly observes that firms keep track of the time that an attomey spends on a particular matter by monitoring the lawyer's billable hours. Id. at 1914-15. Moreover, as we explain below, firms can also structure their work practices to ensure that senior lawyers gain a certain amount of the information they need to measure lawyer quality in the normal course of doing their work (i.e., by requiring senior lawyers to review the work of junior lawyers). Where Kordana errs is in assuming that these sources of information provide an accurate measure of lawyer quality. See id. at 1915-16. While billable hours may be a reasonable measure of lawyer effort (although rampant reports of fraudulent billing practices by both junior and senior lawyers cast doubt upon even 
about lawyer quality, a firm would have to look behind both results and work product to determine whether the lawyer considered all of the relevant legal and factual considerations that might bear on the decision at hand. To accomplish this task, the evaluator must have both the technical expertise to identify considerations that may have been overlooked (or misinterpreted) and sufficiently developed powers of professional judgment to assess the discretionary judgments underlying the first lawyer's decisions. Like training, this process is expensive because it necessarily involves senior lawyers whose time could be used more productively elsewhere. ${ }^{107}$

Recent changes in size, structure, and operation of corporate firms present firms with a host of new monitoring and training problems. ${ }^{108}$ As firms grew in size and geographic scope, ${ }^{109}$ their hiring needs expanded as well. Correspondingly, the opportunities for partners to

this limited claim), they are a very crude measure of the quality of that effort. As Gilson and Mnookin argue:

Shirking involves more than simply putting in too few hours. In this respect, the shortcoming of a time-keeping system is the same as ... with any productivity formula: It is merely an imperfect proxy for what is really sought to be measured-effcctiveness of legal work.... There is an enormous difference between the performance of a lawyer who is simply putting in his time and that of a lawyer who is truly motivated to produce.

Gilson \& Mnookin, Human Capitalists, supra note 63, at 374.

107. Kordana errs once again when he asserts that "monitoring the quality of [an associate's] output is not usually a cost to the firm" because clients pay partners to review associates. Kordana, supra note 106, at 1915. Time spent reviewing associate bills and evaluating whether the associatc's time was well spent is costly to the firm even if partners can bill all of this time to clients-a questionable assumption in today's competitive legal marketplace. As the new productivity based compensation systems employed by most firms attest, the most productive use of a partner's time is in finding new clients rather than in servicing old ones-let alone billing clients for past services. Time spent monitoring is time that cannot be spent developing new business. Not surprisingly, firms seek to avoid these opportunity costs as much as possible. As we argue below, regardless of whether the "promotion to partnership tournament" accounts for the rapid growth in firms over the last two decades, it is a rational response to the difficulty of accurately judging the quality-as opposed to the quantity - of a lawyer's work. See infra Part II.B.2.

108. For a general description of recent changes in corporate lav firms, see Galanter \& PALAY, supra note 24, at 37-76; KronMaN, supra note 91, at 273-307.

109. For our purposes, it is not important to identify any single cause for this growth. For a discussion of law firm growth, compare GALANTER \& PALAY, supra note 24, at 77-120 (arguing that toumament theory explains large law firm growth), with Kordana, supra note 106, at 1923-33 (arguing that law firm growth is better explained by the "produetion-imperatives" of the work these firms do for their clients). In contrast to both of these views, we believe that there is credible evidence that a variety of factors, including, inter alia, the inherent dynamics of partnership tournaments, the needs of clients, the potential for extracting higher profits through leverage, and status competition among firms for the coveted desiguation of being a "national"-or inereasingly a "global"-leader in the corporate law firm world contributed to the rapid escalation in firm size. (On this last point, see Lincoln Caplan's description of how Skadden lawyers measured their status vis-avis their more established New York competitors by scrupulously keeping track of their relative size. See CAPLAN, supra note 67, at 56). Our interest is simply in understanding how law firm size affects monitoring costs. 
monitor associates directly decreased. ${ }^{110}$ This trend has been exacerbated by both the growth in the size of today's corporate and litigation projects and increased specialization among attorneys at all levels. Larger projects in the litigation and corporate areas have produced larger and more highly leveraged teams of lawyers. ${ }^{111}$ As a result, partners have less contact with each associate on the team and are less likely to work jointly with associates on specific projects. ${ }^{12}$ The fact that most firms are also more highly leveraged than they were in the past (that is, they have increased the ratio of associates to partners) further increases monitoring costs. ${ }^{113}$ Similarly, specialization and the departmentalization that has followed in its wake reduce contact among lawyers across specialty areas and increase the difficulty of making accurate subjective evaluations of quality across departmental lines.

Size and leverage also affect the credibility of the firms' training and out-placement promises. Law school graduates still must be trained if they are to become effective lawyers. The same factors that have made direct monitoring more difficult (for example, larger teams, greater task differentiation between partners and associates, etc.) also reduce opportunities for partners to train associates. Moreover, as corporate clients have become more savvy and articulate about protecting their interests, they are less willing to pay for associate training. As a result, firms are under pressure to find ways to reduce the amount of money that they have to spend on recruiting, training, and monitoring without endangering either quality or competitiveness. ${ }^{114}$ As our general model predicts, many firms have gravitated towards a combination of

110. It is now quite common for partners at large firms to bemoan the fact that they barely recognize their fellow partners, let alone have any significant contact with the vast majority of the firm's associates-even those associates who are eventually considered for partnership. See CAPLAN, supra note 67, at 263-74 (describing the partnership selection process).

111. See Robert J. ARndt, Managing for Profit: IMProving or MaIntaining Your BOTTOM LINE 72 (1991) (arguing that today's litigation work permits firms to maintain a relatively high associate/partner ratio). Not all law firm departments are organized in this fashion. See Kordana, supra note 105, at 1925-28 (documenting that tax departments are less highly leveraged than either litigation or corporate departments). We return to this distinction below.

112. See Nelson, supra note 24, at 180 (noting that in modem law firms, "partners and associates perform very different tasks"); Samuelson, supra note 63, at 648 (noting that today's senior partners "do not write research memoranda or draft interrogatories; they reserve their energies for complex issues of law and strategy").

113. See James W. McCrae, Strategies for Dealing with Slow Growth or No Growth, LAw PRACTICE MGMr., Dec. 1992, at 29 (describing high leverage rates of the 1980s). As Galanter and Palay note, for many firms both inside and outside New York, partnership rates actually rose during the boom years of the 1970s, while the number of years to partnership fell. See GalanTER \& Palay, supra note 24, at 62-63. Since 1980, however, both trends have reversed. Id. at 63-64. These latter trends have intensified during the belt-tightening years of the 1990s.

114. See Rita K. Stropus, Mend it, Bend it, and Extend it: The Fate of Traditional Law School Methodology in the 21st Century, 27 Loy. U. CHI. LJ. 449, 470-71 (1996) (noting that with the breakdown of long-term relationships between clients and firms, clients are less willing to pay for associate training). 
high wages and a series of complex hierarchical institutional practices as a means of reducing these expenditures.

\section{An Efficient Model in an Age of Opportunism}

Three interlocking structural components typify contemporary elite firms: high wages, a steep pyramidal structure in which all lawyers compete in a series of tournaments and there is pressure to reduce work to its smallest and least demanding unit of measure, and an informal tracking system that separates associates who will be trained from those who will not. ${ }^{115}$ Each of these institutional characteristics and the previously mentioned monitoring problems are discussed below.

\section{a. High Salaries}

High associate salaries are now a standard fixture of the elite law firm world. This was not always the case. Prior to the late 1960 s, these firms paid their associates no more-and in some instances less-than most of these young lawyers could earn in other sectors of the legal economy. ${ }^{116}$ Beginning with the so-called "Cravath shock" in $1968,{ }^{117}$ starting salaries for associates have skyrocketed to more than $\$ 85,000$ a year in New York and other comparable cities. ${ }^{118}$ On average, associates now earn as much as $72 \%$ more than their counterparts in government. ${ }^{119}$ A considerable gap also exists between associate compensation and salaries paid by corporate legal departments, small firms, and aca-

115. Needless to say, not every large law firm follows all aspects of the strategy we outline below. Law firms, like other similar organizations, vary in their structure, culture, and practice. See, e.g., NELSON, supra note 24, at 51-52 (describing the difference between "general service firms" and "specialty firms," that provide spot services to a larger number of clients). Nevertheless, the policies and practices are common among firms of this type. Moreover, to the extent that these practices we describe are efficient, competitive pressures will push firms to adopt them. These pressures help to explain the growing similarity among corporate firms in various regions of the country. As we argue below, however, there is nothing inevitable about this result. See infra Conclusion.

116. For example, in 1954, the mean income for law firm associates in the United States was $\$ 7,786$ as compared with $\$ 7,915$ for government lawyers. ABEL, supra note 38 , at 302 . The late Professor and former Dean of the Harvard Law School Albert Sacks once told Professor Wilkins that when he joined Covington \& Burling in 1950 after clerking for Justice Felix Frankfurter, he took a significant pay cut, and that when he joined the Harvard Law School Faculty two years later, he received a substantial pay raise.

117. In 1968, the Cravath firm, breaking with the unofficial cartel that had set New York salaries for the preceding decades, increased starting associate salaries from $\$ 10,500$ to $\$ 15,000$. See Galanter \& Palay, supra note 24, at 56. These raises were then matched by the major New York firms and also exerted upward pressure on salaries in comparable firms around the country. Id.

118. See Edward A. Adams, Firms Give "Going Rate" Gentle Boost, N.Y. L.J., Apr. 17, 1995, at 1 .

119. See Marcia Coyle \& Marianne Lavelle, 1 of 11 Federal Attorneys Quits Each Year, Nat'L L.J., Sept. 11, 1989, at 5 (citing a $72 \%$ pay gap between senior corporate attorneys and govemment lawyers with similar experience); Closing the Gap. Nat'L L.J., Mar. 27, 1989, at 12 (arguing that associates make more than double the salary of comparable government lawyers). 
demia. ${ }^{120}$ Furthermore, after the second "Cravath shock" in 1986, associates' salaries are now comparable to those of their counterparts in consulting firms and investment banks. ${ }^{121}$

Nor can these differences in salary be explained solely on the ground that associates at elite firms are either better prepared or more productive than those who work in other areas. For example, in a comprehensive study of associate salaries in private firms, Rebitzer and Taylor conclude that differences in ability, human capital investments, and working conditions (including hours worked) at most account for between $42 \%$ and $57 \%$ of the wage differential between associates working in elite firms and those in small firms. ${ }^{122}$ Adjusting for these factors, the authors find that "an associate lawyer in the largest firm-size category makes roughly $\$ 11,000$ more per year than her counterpart in the smallest firm-size category." 123

Moreover, these high salaries have proven to be resistant to downward economic pressure. ${ }^{124}$ During the recent recession, not a single firm cut its starting salary for fear that the move would signal to potential recruits (as well as to clients) that the firm was in economic trouble. ${ }^{125}$ Nor have most firms created salary differentials among associates or established a separate category of "contract" lawyers who are paid lower salaries and are excluded from partnership consideration. ${ }^{126} \mathrm{De}$ spite the obvious cost savings of both of these strategies, most firms have been dissuaded by the costs of increased monitoring and lowered mo-

120. See ABEL, supra note 38 , at 166-75, 206-07 (reporting salary differentials between corporate lawyers and other sectors of the profession).

121. In 1986 , Cravath raised starting salaries from $\$ 53,000$ to $\$ 65,000$, in part due to competition from investment banks. See GALANTER \& PALAY, supra note 24, at 56-57 (describing the second Cravath shock); Tamar Lewin, The Faster Track: Why Law Firms Are Losing New Talent to Investment Banks, L.A. DAILy J., Aug. 14, 1986, at 4. As a result, the "going rate" for associates is equivalent to (and in many cases exceeds) the starting salaries paid in comparable occupations. See John E. Morris, Cut the Going Rate, AM. Law., Sept. 1993, at 5, 77 (reporting that from 1982 to 1993 the consumer price index rose $41 \%$, salaries for Harvard MBAs $31 \%$, base pay for consultants $45 \%$, and starting salaries for associates $78 \%$ ).

122. See Rebitzer and Taylor, supra note 102, at 696-97.

123. Id., at 697.

124. For example, the starting salary for associates in New York City has remained constant at approximately $\$ 83,000$ even though the number of job openings dropped by $50 \%$ during the period from 1989-92. See Morris, supra note 121, at 77.

125. See id. (noting that firms refrain from cutting salaries in tough economic times because they do not want to be perceived by clients and potential associates as being in financial distress). As Morris notes, however, less visible items of compensation, such as bar exam stipends, generosity in expense reimbursements, leave policies, etc., vary considerably across firms in the same geographic locale. See John E. Morris, How Do You Measure Up?, AM. LAw., Sept. 1993, at 67-75.

126. On differential compensation systems for associates, see Attorneys and Dollars, NAT'L L.J., Aug. 1994, at 27. On the growth in "contract" lawyers, see Michael Orey, Staff Attorneys: Basic Work at Bargain Prices, AM. LAw., Sept. 1987, at 20 (discussing Jones Day's program). 
rale that appear to flow from making these distinctions among associates. ${ }^{127}$

Despite the frequent protestations by law firm hiring partners to the contrary, there is ample evidence that the high salaries paid by corporate firms are efficient from the perspective of recruiting and monitoring. Many students state that the high salaries paid by corporate firms are the primary reason they choose jobs in this sector over what they consider to be more rewarding work in government or public interest practice. ${ }^{128}$ More importantly, once an associate joins a corporate firm, the high salaries and other benefits create a substantial inducement to stay. After years of deferred gratification, many associates find irresistible the prospect of acquiring a lifestyle that is commensurate with (if not greater than) their income. Once they have bought (often with the firm's help) the "right" house, the "right" car, and joined the "right" clubs, however, they are dependent on continuing to earn the "right" income which they can only do by staying at the firm. ${ }^{129}$

Moreover, the fact that elite firms also hold out the possibility of partnership as a means of inducing associates to work hard and stay in their jobs does not render high associate wages superfluous for these

127. See Alison Frankel, Debevoise Doesn't Budge, AM. LAw., June 1993, at 76, 78 (noting that Debevoise \& Plimpton has concluded that lockstep compensation improves morale and firm collegiality). In addition, it is possible that creating a separate tier of "contract" lawyers is less advantageous than making better use of paralegals. During the last two decades, the number of paralegals employed by large law firms has skyrocketed. See Galanter \& Palay, supra note 24, at 65 (reporting that the number of paralegals in large firms went from 14,000 in 1972 to 83,000 in 1989). As we note below, paralegals now perform a substantial number of routine legal tasks (including drafting, basic research, keeping track of documents) that once were the sole province of associates. See infra note 192 and accompanying text. By increasing the amount of work given to paralegals, firms can simultaneously cut client costs while increasing profits since paralcgal hours are directly billed to clients at rates that substantially exceed their costs. See AbEL, supra note 38, at 198 (arguing that "paralegals generate between two and three times as much income for their firms as they cost in salary (and require less overhead than associates)"). Moreover, paralegals must be supervised by associates, who in turn bill this time to clients. Finally, a firm that uses this strategy can avoid the obvious problem of having to tell its clients that less than "the best" lawyers have been assigned to their cases.

128. See Robert Granfield, Making Elite Lawyers: Visions of Law at Harvard and BEYOND 151-53 (1992) (reporting that the high salaries paid by corporate firms are a substantial inducement for Harvard law students who decide to work for corporate firms, particularly for those with large loan burdens). Luring potential recruits from the newly emerging public interest and legal services sectors was one of Cravath's primary motivations for administering its first shock to the going rate in 1968. See Galanter \& PALAY, supra note 24, at 56 . Even if they are not primarily interested in money (which many may be), applicants may mistake high salaries for a guarantee of firm quality (including the firm's financial health and stability), distrust their ability to judge nonmonetary compensation (such as training, interesting work, or quality of life), or believe that it is impossible to hold firms to their promise to deliver these other goods.

129. It is for this reason that associates often refer to their high salaries and other benefits as "golden handcuffs." See Edward A. Adams, Cravath Raises Current Associates' Pay, N.Y. L.J., Dec. 20,1994 , at 1 . 
purposes. ${ }^{130}$ Although the promotion-to-partnership tournament might be a sufficient solution to the monitoring problems we describe if every associate actually participated in this process, both empirical and anecdotal evidence about associate career paths suggests that this is no longer the case. For reasons that we discuss more fully in the next two sections, a substantial number of the associates joining large law firms have at best a weak commitment to staying with the firm long enough to be considered for partnership. ${ }^{131}$ For these associates, the high wages paid by corporate firms are a substantial inducement to work hard in order to retain these coveted positions until they decide that they are ready to leave-a decision, as we indicated above, that the salary differential between elite firms and other legal employers may help to delay or even to change. ${ }^{132}$ Cravath's latest "shock" to the prevailing salary structure-a $30 \%$ increase in the salaries of senior associatesdemonstrates how much firms use high salaries as a means of motivating and retaining associates who have, given Cravath's notoriously low partnership rates, little chance of winning the promotion-to-partnership tournament. ${ }^{133}$

The downturu in corporate legal services in the early 1990s has only served to reinforce these incentives. Associates are now acutely aware that they face the possibility of being laid off in tough economic times and that firms have the incentive to portray this decision as based on the associate's quality rather than on the firm's poor economic performance. ${ }^{134}$ Given that other potential 'employers will have relatively little information about the quality of an associate who loses her job, the

130. See Rebitzer and Taylor, supra note 102, at 697-98 (speculating that firms do not pay high wages to induce effort or save on monitoring costs because these problems are adequately taken care of by the incentives created by the promotion to partnership toumament).

131. See Kordana, supra note 106 (noting that many associates who now join large law firms have no intention of trying to make partner).

132. In this respect, high wages complement toumaments by inducing some associates to stay with firms long enough to invest (hoth psychologically and financially) in the possibility of becoming partners. This reinforcing effect is particularly powerful with respect to those associates whose declared intention to stay at a firm for only two years is more a device for reconciling their ideological commitments with their material interests than a real statement of interest. See GRANFIELD, supra note 127, at 151-52 (arguing that when Harvard law students state that they only intend to stay at their firms for two years to pay off their loans they are engaged in a form of ideological work).

133. See Adams, supra note 129 (observing that the increase was a result of Cravath's inablity to retain senior associates). It remains to be seen whether these raises will actually induce associates to stay in circumstances where their prospects for winning the toumament would not justify reducing their chances of securing a good job in the lateral market. Cf. John E. Morris, Weil, Gotshal's Generation Gap, AM. LAw., Dec. 1995, at 5 (discussing the problems of retaining senior associates at New York's Weil Gotshal).

134. See David Machlowitz, How to Counterattack If You're Losing Your Job, BARRISTER, Spring 1991 , at 16 ("To add insult to injury, many of the firms claimed the wholesale firings did not mean the firms' revenues were down, but rather that the firings were "strictly on the basis of merit."'). 
negative signal that she has been "laid off" is likely to have draconian consequences for her future employment prospects. Moreover, since associates are aware that firms have relatively little information about actual associate quality (particularly in the early years) they know that decisions about whom to lay off can be based on a wide array of small and potentially random distinctions. They therefore have a strong incentive to ensure that all aspects of their performance (from hours to dress code) are beyond reproach.

In sum, the high wages paid by elite firms help to create a culture of fear that motivates associates to work hard even in the absence of extensive monitoring. Not only do associates know that there are a large number of capable lawyers who would love the chance to work at one of these high paying jobs, but they are also aware that any hint that they are leaving their firm on anything less than the best of terms will have a devastating effect on their future employment prospects. ${ }^{135}$ Even those who do not see themselves as having long term careers with the firm have an incentive to work productively as a means of keeping their options open. The pyramidal structure employeed by many large firms reinforces these effects.

\section{b. Pyramiding}

Even before they began paying high salaries, law firms employed a promotion-to-partnership tournament to induce both hard work and loyalty. The basic parameters of this competition have remained fairly constant: firms pay recent law school graduates along a fixed salary scale for six to ten years, at the end of which time they promise to promote those associates who have demonstrated that they have the greatest potential for making long term contributions to the firm. ${ }^{136}$ This practice tends to produce a pyramid structure, since in order to be an effective substitute for direct monitoring, there must be fewer tournament winners than entering associates. Recent changes in the size, competitiveness, and profit structure of large law firms, however, have accentuated this trend.

As elite firms have grown in size, they have also tended to become more highly leveraged. The reasons for this change are straightforward. Partners make money on the surplus of revenues generated by associates over the amount they are paid. Although the high salaries paid to associates increases the cost of leverage, these costs are more than offset

135. As the head of the bankruptcy practice at an elite New York law firm is reportcd to have told his associates (during a morale boosting talk') a few months after a wave of firings at the firm: "Well, there is one thing I want to say to you. There are no jobs out there. But there are thousands of people who could do your jobs just as well as you. Think about it." Jonathan Foreman, Poor People Skills Can Collapse Firms, NaT'L L.J. 1, Jan. 29, 1996.

136. See Galanter \& Palay, supra note 24, at 100. 
by the profits these lawyers generate from the time that they join the firm. ${ }^{137}$ As a result, the size of a firm is positively correlated with partner income. ${ }^{138}$ Moreover, the smaller the number of partners entitled to share in this profit, the bigger each individual partner's share is likely to be. Not surprisingly, as the larger classes of associates hired in the boom years of the 1970s and 1980s moved through the system, many firms decided that "there [was] just not room at the top" to accommodate even the same percentage of partners that the firm was prepared to make from the smaller associate classes of the $1960 \mathrm{~s}^{139}$

In addition, the growing competitiveness of the legal market has also led law firms to institute a new tournament to solve a problem that, for many, has proved to be even more important and intractable than the problems of monitoring and motivating associates: preventing shirking by partners. Traditional structures such as lifetime tenure, lock-step compensation, and autonomous working conditions afford partners ample opportunity to shirk on both the quantity and quality of their work for the firm. ${ }^{140}$ At the opposite extreme, non-shirking partners (particularly those with their own clients) now have access to an active lateral market where they can sell their services to the highest bidder. $^{141}$

Firms have generally responded to these problems by raising the income of productive partners and by cutting the compensation ofand in some cases dismissing-unproductive partners. ${ }^{142}$ At the same time, many firms have effectively recreated the promotion-to-

137. As Richard Abel cogently argued in 1989, "If we make the ... realistic assumption that starting associates are billing 2000 hours annually at $\$ 75$ an hour, they easily earn the firm more than three times their salaries, even though these now start at more than $\$ 50,000$ at some firms." ABEL, supra note 38, at 192. To be sure, the firm must pay the associates' overhead out of these profits (e.g., secretarial support, office space, supplies). Moreover, it is possible that firms will not be able to bill every hour a beginning associate works to a client. Despite these caveats, however, many observers believe that associates become profitable almost immediately. See, e.g., Steven Brill, The New Leverage, AM. LAw., July/Aug. I993, at 5, 65 (arguing that under traditional billing practices, law firms make profits on associates "after 1,200-1,400 hours" depending upon overhead); James F. Fitzpatrick, Legal Future Shock: The Role of Large Law Firms by the End of the Century, 64 IND. LJ. 46I, 464 (1989) (arguing that associates are immediately profitable); NELSON, supra note 24, at 77 (same). As we argue below, the less resources firms spend on training a given associate, the higher will be their retum on these hours. See infra text accompanying note I49.

I38. See ABEL, supra note 38, at 194 (citing data).

139. See Peter Griggs \& Daviryne McNeill, Upper Ranks Add Heft at Most Big D.C. Firms, Leg. TIMES, Dec. 28, 1987-Jan. 4, 1988, at 4.

I40. See Gilson \& Mnookin, Human Capitalists, supra note 63, at 34I-46 (describing how traditional partnerships are vulnerable to partner shirking).

141. See Galanter \& Palay, supra note 24, at $54-55$ (describing the lateral market for partners).

142. See ABEL, supra note 38, at I85. Significantly, the few firms that have resisted this trend (e.g., Cravath and Cleary, Gottlieb) are among the most highly leveraged (and therefore most profitable) firms in the country. 
partnership tournament for partners by establishing multi-tiered partnership systems. ${ }^{143}$

These changes in the structure of large law firms threaten to undermine the effectiveness of the promotion-to-partnership tournament as a device for motivating associates to work diligently and competently with relatively little supervision. The combination of diminished chances of becoming a partner and reduced rewards (e.g., diminished job security, greater delay in obtaining substantial financial rewards) for those who win the tournament are likely to lead some number of associates to conclude that becoming a partner is neither sufficiently plausible - nor perhaps even sufficiently desirable - to justify the tremendous sacrifices that it takes to reach this goal.

This dynamic presents two challenges for elite firms. First, many associates do not see themselves as participating in the tournament. Second, because outside employment prospects are likely to decrease the closer they get to the partnership decision, firms will have difficulty retaining senior associates. ${ }^{144}$

The pyramid structure ameliorates both of these potential pitfalls to firm profitability. As Heinz and Loumann observe: "In the practice of law-as on the assembly line and in many other sorts of work-an almost inevitable consequence of the division of labor has been a routinization of tasks for most of the workers." 145 Both client pressures and the firm's economic interests dictate that wherever possible, work should be divided into those aspects that require discretionary judgment and those that do not, with the latter "flow[ing] to the lowest level within the firm that can perform it satisfactorily." "146 As a result, firms generate a

143. See altman \& Weil, Inc., Compensation Plans for lawyers and Their Staffs: Salaries, Bonuses AND Profit-Sharing II (1986) (reporting that one-half of all firms with 75 or more lawyers had at least two classes of partners); D. Weston Darby $\mathrm{J} r$., Are You Keeping Up Financially?, A.B.A. J, Dec. 1985, at 66, 68 (reporting that $25 \%$ of a sample of 150 large- and medium-size law firms had more than one class of partners). Kordana is therefore right to note that monitoring problems among partners should lead to partners engaging "in a series of tournaments throughout their careers." See Kordana, supra note 106, at 1917 \& n.54 (using this prediction to dismiss tournament theory). Given these multi-level partner compensation systems and the everpresent danger that unproductive partners will be fired, many partners effectively do face an almost endless series of promotion contests.

144. See Morris, supra note 133, at 5, 7 (discussing the problem of retaining senior associates (years seven to ten) because of the difficulty they face in getting jobs elsewhere if they do not make partner); Gilson \& Mnookin, Coming of Age, supra note 63, at 591 (discussing the negative effects of being tumed down for partnership on an associate's out placement prospects). We return to this issue below. See infra note 288 and accompanying text.

145. HeINZ \& LAUMANN, supra note 66 at 133-34.

146. John G. Iezzi, Results-Oriented Financial Management: a Guide to Successful LaW Firm Financial Performance 7 (1993). Dividing projects in this fashion arguably serves both the firm's interest (in maximizing the number of timekeepers billing on a given matter) and the client's desire to pay the higher rates charged by partners and senior associates only when successful completion of the task actually requires the kind of discretionary judgment these senior lawyers 
good deal of "repetitive and ministerial tasks" that can be proftably be assigned to junior associates. ${ }^{147}$ This, in turn, helps to insulate firms from the economic consequences of the high associate turn-over rates produced by the diminished attractiveness of the promotion-topartnership tournament.

Nevertheless, firms must still produce senior lawyers who both monitor the ministerial work of junior lawyers and perform those tasks that do call for expertise or judgment. This brings us to the issue of training.

\section{c. Tracking and Training}

The continued viability of any elite law firm rests on its ability to reproduce its partners and to maintain a cadre of able and motivated senior associates. Although firms can look to the burgeoning lateral market to satisfy some of their needs, most senior lawyers must come up through the ranks. ${ }^{148}$ As a result, firms must invest some resources in training.

Given their pyramid structure, however, it is grossly inefficient for firms to train all of their associates. This structure ensures that most associates will leave the firm before becoming partners. Hence, while the firm needs a few trained senior associates, it has little incentive to

should have acquired during their tenure with the firm. We return to this tension below. See infra text accompanying notes $155-156$.

147. KRONMAN, supra note 91 , at 285-86. Kronman's assessment is confirmed by a host of testimonials by young lawyers reported in a recent "insider's guide" to life in large law firms. See The INSIDER's Guide to LAW Firms 331 (Sheila V. Malkani \& Michael F. Walsh eds., 1994) [hereinafter "INSIDER's GUIDE"] (quoting associates at Chadbourne and Park as complaining that most corporate and litigation associates handle "mundane" drafting and research assignments and deal with "a lot of paper"); $i d$. at 351 (reporting that associates at Dewey Ballantine complain that their assignments involve "grunt work that has nothing to do with legal work"). Of course, not every area of practice lends itself to this kind of division. For example, litigation and general corporate departments are more highly leveraged than tax departmcnts. See Kordana, supra note 106, at 192528 (linking the lower leverage rates in tax departments to the fact that there is less "paperwork" to be done in this area). Moreover, just because work is "repetitive and ministerial" does not mean that it is not important or that large negative consequences-such as losing clients or suffering malpractice judgments-might not result from an associate's failure to perform one of these simple tasks in a competent and timely fashion.

148. Theoretically, a firm could rely entirely on the lateral market to satisfy its need for qualified senior associates. Although many firms actively recruit senior associates, several factors limit the usefulness of this strategy. First, if a firm relied entirely on lateral entrants, the firm's own associates would have no incentive to participate in the promotion-to-partnership toumament since this tournament would have no winners. Moreover, a senior associate is only valuable if she has been vell trained. As we have said throughout, firms will have a difficult time making this kind of quality judgment in all cases. Given that the firm is likely to have better information about its own lawyers than those working at other firms, however, it has good reason to believe that subjective quality judgments about the former group will be more reliable than evaluations of outsiders and therefore has an incentive to promote its own associates. Finally, there is some reason to believe that homegruwn senior associates and partners will be more loyal to the firm than those who have already shown their willingness to switch firms when a better offer comes along. 
invest scarce training resources on lawyers who are not going to stay at the firm long enough for the firm to recoup that investment. ${ }^{149}$ Moreover, so long as there is work that can be done profitably by inexperienced lawyers, firms have an incentive to keep some number of untrained associates on their staffs.

In addition, even if the firm as a whole has an interest in ensuring that every associate gets some minimal level of training, individual partners do not. Associate training is both a public good for the firm and a private good for individual partners. The firm as a whole arguably benefits when all associates receive some credible level of training. ${ }^{150}$ Individual partners, however, have sub-optimal incentives to contribute to the production of this firm-wide benefit. Training is costly to individual partners; time spent training is time that the partner cannot spend either producing revenue or consuming leisure. The benefits of training, on the other hand, are diffuse. To be sure, every partner needs a certain number of well-trained associates to do his or her work. Time spent training these associates produces private gains for the partner-if that associate continues to work for the training partner. Given that associates typically work for more than one partner, however, no individual partner will be able to capture the full value of time invested in training. ${ }^{51}$ As a result, partners have strong incentives to ration time spent on training and to invest only in those associates who are likely to benefit them and their practices directly.

Given these incentives, we expect partners to make decisions about how to staff projects according to the following criteria: ${ }^{152}$

First, partners will have a preference for associates who need little or no training. Monitoring the work of other lawyers is both difficult and expensive. Partners want to staff their projects with associates who

149. The incentive to invest in those who will leave is not zero, since firms want to maintain the good will of lawyers who may end up working for potential clients.

150. We assume that well-trained lawyers are generally more productive (even on menial tasks) and that associates value training and are therefore more likely (all else being equal) to apply to and select firms that provide this good. These benefits would still have to be weighed against the cost of training all associates and the danger that even firms that do so will lose associates to their competitors who will then reap the benefits of the training without incurring the costs. As we argue below, this trade-off helps to explain why firms have moved to formal training programs, which allow them to hold themselves out as offering real training without having to incur the substantial costs associated with supervisorial training. See infra text accompanying notes 361-370 (discussing formal training programs).

151. In firms in which a relatively small number of partners freely share trained associates, as well as the revenues generated by all partners, this externality is not very important since each partner has an important incentive not to shirk his or her fair share of the training duties. Moreover, in small firms, it is easier for partners to monitor each other for compliance with this mutual obligation. For the reasons discussed above, this mutual monitoring is now less likely. See supra text accompanying notes $108-113$ (discussing size and specialization).

152. This description assumes that there is no formal training or assignment system. In Part IV, we examine how various formal assignment and training systems might alter these incentives. 
will be able to do the work with relatively little supervision. Finding lawyers who can perform tasks competently and quickly is therefore the preeminent selection criterion.

Second, if the partner can secure the services of such an associate, the partner will invest in further training that lawyer. Although this seems paradoxical (since the lawyer was selected because he or she only needed minimal training to do the job), training superstar associates is nevertheless an important part of the implicit bargain that partners strike with these new entrants and their colleagues. ${ }^{153}$

Third, to the extent possible, partners will leave training and supervisory functions to senior associates. These lawyers, however, have little incentive to invest in training, as opposed to supervising, their charges. As an initial matter, there is a limit to what any particular senior associate knows. More importantly, since senior associates are also competing for scarce training opportunities and attempting to signal partners that they are well trained, these associates have an incentive to keep good work assignments (e.g., those involving client contact, court appearances, or plum writing assignments) for themselves instead of passing them down the line. The fact that only a few of these lawyers will become partners further increases their incentive to take credit for good work done by their juniors and to blame their charges for their own mistakes. ${ }^{154}$

As a result, associates will gradually be divided into two broad categories: those who have received training (or are considered worthy of receiving training) and those who have not (and who are not considered good training prospects). Although the boundaries between these two groups are fluid, they nevertheless will tend to be self-perpetuating. Trained associates can lose their privileged status by making mistakes that cause partners to doubt that their training investment will be recouped (or to suspect that the reputational costs of being seen as pushing a relatively weak associate outweigh the benefits of providing training). Similarly, previously untrained associates can come to the attention of partners by doing exemplary work on routine assignments. More often, however, once an associate has been trained, other partners have an incentive to use her and to provide additional training. Those

153. As an initial matter, a partner may hope that if she trains a superstar associate, that associate will be more likely to want to work with the partner in the future. To the extent that partners must inevitably share associates, providing good training to someone else's protege makes it more likely that your protege will also receive good training when working for others.

154. See D. Jean Veta, Grabbing the Brass Ring: Making Parther at a Large Firm, in THE Woman Advocate: Excelling In the 90's (Jean M. Snyder \& Andra B. Greene eds., 1995), at 265,274 . Although partners can increase a senior associate's incentive to invest in training junior lawyers by weighting this factor more heavily in their calculus for making new partners, the difficulty of differentiating senior lawyers on this basis is likely to deter partners from adopting this strategy. 
who do not get trained, on the other hand, are less likely to receive the kind of work that will give them the opportunity to become trained (or otherwise to demonstrate their talent).

Those who have not been trained face diminishing opportunities for success. Although we have seen that firms generate a substantial amount of relatively routine work, clients will not pay for this work to be done by senior associates when it can be handled just as effectively by lower-cost junior associates. ${ }^{155}$ As a result, an associate who has not been trained will gradually find that she has less and less work assigned to her as the firm becomes unable to bill her increasingly expensive time to clients. ${ }^{156}$

Figure 1 portrays this divergence. The curved line denoting associates receiving training represents the standard story told to law students by every hiring partner during recruiting season: "Our firm loses money on associates during the first several years because we invest heavily in training these young women and men to become excellent lawyers. Even if you only stay at our firm a few years, you will develop the skills and dispositions that will help you succeed at any legal job you choose to take on."157 The flat line denoting associates who are not receiving training, however, portrays the reality that many enthusiastic recruits find when they join elite law firms: an initial period of grinding but undemanding work, followed by a gradual slow down until they are gently but firmly told that their services are no longer needed. ${ }^{158}$

155. See Abram Chayes \& Antonia H. Chayes, Corporate Counsel and the Elite Law Firm, 37 StAN. L. Rev. 277, 291-92 (1985) (reporting that corporate counsel monitor firms for overstaffing and overbilling).

156. Firms, of course, have an incentive to prolong this process as long as possible since a senior associate's higher billing rate potentially increases profits. Given that most firms have few senior associates, the opportunity costs of using one of these valuable assets in such a relatively unproductive manner is high enough to discourage firms from indulging in this mild form of overcharging.

157. For an example of this kind of rhetoric, see, e.g., Joel F. Henning, Maximizing Law Firm Profitability: Hiring, Training and Developing Productive Lawyers 3-1 (1991) (waming that many associates are not interested in long-term careers with firms; "[i]nstead, they seek postgraduate skills training to become competent lawyers, and they know that the private corporate law firm is the best place to acquire that training").

158. As with any model, Figure 1 oversimplifies the phenominon it attempts to represent. For example, because firms take time to determine which associates will receive training, there is a period where the marginal productivity of all associates (by which we simply mean the nct income an associate generates for the firm) is roughly the same. In addition, the marginal productivity of associates who do not receive training never flattens out completely, since over time these lawyers become more proficient at the routine tasks to which they are assigned. Notwithstanding, these simplifications, Figure 1 captures the essential difference between associates who are being trained and those who are not. It also explains why the barrier to moving from the "flatlining track" to the "training track" becomes more solid as time passes. Higher billing rates both increase the opportunity costs associated with training senior associates and reduce the potential benefits since their expected future at the firm is shorter. This combination makes it extremely unlikely that partners will decide to invest in their training. Cf. Note, Why Law Firms Cannot Afford to Maintain the Mommy Track, 109 


\section{FIGURE 1}

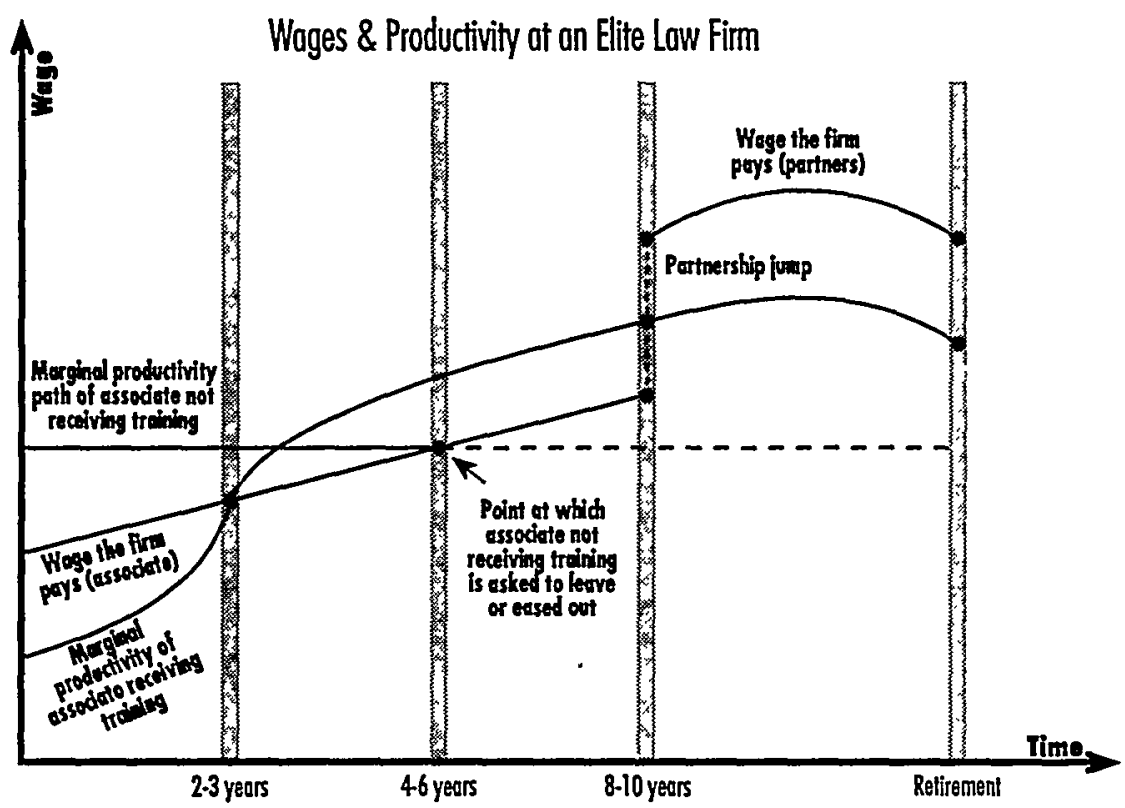

The separation of associates into a "training track" and a "flatlining track" highlights two important differences between elite law firms and the organizations portrayed in standard touranment theory models. First, contrary to standard tournament theory, firms do not run a competition in which every associate is given an equal chance to succeed. ${ }^{159}$ Instead, from a very early date, firms begin giving some employees the capital that it takes to succeed in the firm while failing to provide this essential good to others. An analogy can be drawn to the social structure of bees. ${ }^{160}$ If a bee larvae is fed a rich nutrient (called "Royal Jelly") by the queen, that bee will develop into a queen. ${ }^{161}$ If that same bee receives no Royal Jelly, it will develop into a worker bee. ${ }^{162}$ Training is the Royal Jelly of elite law firms. Those who receive it have a realistic chance of becoming "queens" capable of supporting their own cadre of worker bees. Those who do not are destined to remain worker bees whose usefulness to the hive will eventually draw to an end.

HARv. L. REv. 1375, 1379 (1996) (with constant pressure on partners to improve their productivity, they have only a finite amount of time to invest in training associates).

159. See generally, Rebitzer and Taylor, supra note 102, at 681-84 (describing the standard assumptions underlying toumament theory).

160. We are grateful to Ian Ayres for suggesting this wonderful analogy.

161. See Bernhard GrzimeK, Grzimek's Animal Life Encyclopedia, 461 (2d ed. 1975).

162. See id. 
Second, the process of picking partners is therefore more straightforward than tournament theory suggests. By the time tournament winners are selected, the firm will have had eight to ten years to collect information about which associates are receiving the Royal Jelly of training and to determine whether those who have received this good have developed as expected. Moreover, because firms know both that their future productivity depends upon accurately assessing this information and that associates (particularly senior associates) are in a good position to evaluate the fairness of the firm's partnership choices, firm leaders have strong incentives to weigh the information they collect carefully. As a result, partnership decisions are likely to be much more highly correlated with future productivity than hiring decisions at the associate level. ${ }^{163}$

Success at a large law firm depends, therefore, on not becoming a flatliner, which in turn is dependent on obtaining the Royal Jelly of training. This is true for all associates, white and black. We predict, however, that black associates are, on average, less likely to receive this essential good than their white peers-just as the structure of elite firms makes it less likely that they will be hired in the first instance. The next Part tests this hypothesis in the context of recruitment and training.

III

\section{The Application: Mapping The Racial Law of Averages}

We posit that there are two reasons why discrimination is likely to be a stable equilibrium in firms that employ high wages and complex institutional mechanisms such as touranments and tracking to save on monitoring costs. First, these devices reduce a firm's incentive to detect and correct practices that systematically disadvantage "average" blacks. Second, since blacks therefore face higher barriers to success, they have a corresponding incentive to invest in human capital strategies that, paradoxically, reduce their chances for success even further. In this Section, we explore both of these hypothesies in light of publicly available statistical and anecdotal evidence and our own preliminary data.

Before proceeding, however, it is important to underscore the limitations of this inquiry. Elite law firms have recently become an important subject of academic investigation. ${ }^{164}$ In addition, both the legal and

163. See O'Flaherty \& Siow, supra note 103, at 727 (arguing that firms make correct partnership decisions $82.3 \%$ of the time). The authors nevertheless assert that firms are likely promote a substantial number of "unqualified" associates to partnership. This conclusion, however, is based in part on their assumption that the "qualifications" of potential partners are fixed before they are hired by the firm. See id. at 711 . For the reasons stated above, we believe this assumption is incorrect.

164. See generally GaLANTER \& PaLAY, supra note 24; Gilson \& Mnookin, Coming of Age, supra note 63; Peter D. Scherer, Leveraging Human Assets in Law Firms: Human Capital Structures and Organizational Capabilities, 48 lNDUS. \& LAB. REL. REV. 671 (1995). 
the popular press have taken a substantial interest in these institutions and the lives of the lawyers who work there. ${ }^{165}$ As a result, there is now a substantial volume of information about corporate firms in the public domain. There are, however, limitations on the usefulness and reliability of these accounts. For the most part, the academic literature is theoretical, rather than empirical, often relying on anecdotal evidence from the legal press. ${ }^{166}$ These latter accounts are subject to a variety of familiar defects in terms of selectivity and reliability. ${ }^{167}$ Our own analysis nevertheless follows in this tradition. As a result, our tone is speculative in recognition of the large gaps in our knowledge about the experiences of both black and white lawyers at elite firms.

We have, however, supplemented the publicly available data with our own preliminary research on black Harvard Law School graduates. Our data comes from three sources. First, we examined the data reported in the Harvard Law School Alumni Directory for black graduates of the classes of $1981,1982,1987$, and 1988. Second, we sent out a brief survey to 200 Harvard black alumni associated with the Harvard Black Law Students Association. The overall results of both of these efforts are presented in the Appendix in Tables 1 and 2 respectively. Third, we sent a brief request to 250 corporate firms around the country, asking them to provide information about their entering class of associates for 1995-96. Finally, we have included, where relevant, summaries of comments during interviews conducted by Professor Wilkins.

Our emphasis on Harvard graduates is not simply parochial. Harvard graduates are an important part of the total population of black lawyers. This is true for two reasons. First, Harvard has more black students than any of the other law schools from which elite firms recruit. Second, because we hypothesize that the institutional practices we describe are most likely to disadvantage "average" blacks, the experience of black students from Harvard (given the school's overall reputation for quality and record of successfully placing its graduates) should on average be better (and certainly no worse) than the experiences of

165. See Galanter \& PAlAy, supra note 24, at 68-75 (discussing the "new information order" in which publications, such as the American Lawyer, report on the once-secret world of corporate firms).

166. For three notable exceptions to this trend, see JoHN HAGAN \& FIONA KaY, Gender IN PRACTICE: A Study OF LAWYERS' Lives (1995) (discussing differences among Toronto lawyers); NeLSON, supra note 24 (studying four large Chicago law firms); Chambliss, supra note 7 (studying gender and racial integration in selected firms).

167. On the dangers of relying on anecdotal evidence, see Craig A. Nard, Empirical Legal Scholarship: Reestablishing a Dialogue Between the Academy and Profession, 30 WAKE FOREST L REv. 347, 349 (1995) (criticizing the lack of legal scholarship bascd on statistical data, since without such data it is difficult to draw conclusions or formulate policy). 
blacks from other schools. ${ }^{168}$ If anything, therefore, our emphasis on Harvard graduates should understate the effects we predict.

Once again, it is important to emphasize the limited use to which we intend to put these data. We make no claims that the results of our analysis are statistically significant or that they meet the relevant standards for empirical research. As Tables 1 and 2 indicate, the total number of black graduates included in our two samples is relatively small and we have no way of measuring whether those who answered our survey or sent their information to the Harvard Alumni Office are different in relevant ways from those whom we have failed to locate. ${ }^{169}$ In addition, we do not have comparable data on white Harvard Law School graduates. Nor is there much comparable data on white lawyers in general. We therefore do not claim to have proven anything. Instead, we offer our data, as we offer our model, as an invitation to discussion and further work.

We divide our review of the data into two parts: recruiting and retention. As those concerned with law firn integration consistently report, simply hiring more black lawyers is unlikely to change the racial composition of these institutions in light of the fact that virtually all of these new entrants leave before making partner. ${ }^{170}$ Retention, not recruitment, is therefore the key to increasing the number of black lawyers. Retention, however, is affected by the dynamics of the recruiting process. Obviously, before a black lawyer can successfully move herself on to the "training track," she must first be hired. Moreover, many knowledgeable observers believe that the fewer blacks that a firm already has among its associates and partners, the more difficult it will be to recruit black students. ${ }^{171}$ Conversely, by focusing on a few easily ob-

168. See Mona Harrington, WOMEn Lawyers: Rewriting the Rules 10-11 (1994) (justifying the author's decision to focus on Harvard Law School graduates).

169. Our sample from the Harvard Alumni Directory contains sixty members of the classes of 1981 and 1982, and fifty-seven members of the classes of 1987 and 1988. Appendix, Table 1. In addition, sixty-six black alumni (out of approximately 200 who were sent the questionnaire) returned our survey, including twenty-one pre-1986 graduates and forty-five post-1986 graduates. Appendix, Table 2. There may be some overlap between the Alumni Directory sample and those who returned our survey.

170. "In fact, as in every other major city which has studied the matter, minority retention was stated by the interviewees in every large San Francisco employer to be the firm's most serious problem." S.F. REPoRT, supra note 33, at 17 (footnote omitted). See also Davis, supra note 15, at 1 (reporting "significant attrition in their latter years has left partnership ranks almost as white as five years ago.").

171. "'Recnitment is one thing, but if you can't keep people in, it doesn't do any good. And if you can't keep people in, that hurts you the next time you go to recruit."' Eric Herman, Committee Targets Retention of Minorities at Big Law Firms, CHI. LAW., May 1995, at 13 (quoting W. Muzette Hill, a founder of the Chicago Committee on Minorities in Large Law Firms). See also, Robert Schmidt, Minority Lawyers and the D.C. Firm: Race, Culture, and Sexism Make Integration Difficult at Law Offices, LEG. TIMES, Sept. 26, 1994, at S42, S46 ("Observers agree, however, that no matter how aggressively a firm recruits minority attorneys, if it doesn't have a 'critical mass' of minority 
servable signals that are only loosely correlated with valuable job skills, the recruiting process creates incentives that will adversely affect the retention prospects of those blacks who are hired. It is therefore necessary to look at both recruiting and retention if one is to understand why blacks continue to be underrepresented at corporate firms.

\section{A. Recruitment}

Law firms have changed their hiring practices dramatically during the last thirty years. In the "golden age," the process was both brief and informal, consisting primarily of walk-in interviews during the Christmas holidays. ${ }^{172}$ In that insular world, social connections counted at least as much as academic standing. ${ }^{173}$ Blacks were systematically excluded even in those instances where they clearly met the firm's stated qualifications. ${ }^{174}$

Compared to these not-so-golden practices, the current recruiting system is both open and meritocratic. ${ }^{175}$ Firms now expend enormous resources (in dollars and time) on interviewing second, third, and even some first year students for summer and full time positions. ${ }^{176}$ Moreo-

partners, minority law students or lateral associates will likely look elsewhere."); Chambliss supra note 7 , at 190 . There are a number of reasons why this might be true, including the greater willingness of black lawyers to invest in discovering the actual quality of black applicants, the ability of black insiders to point out and correct for overt and covert discriminatory practices, and the fact that black applicants are more likely to gravitate toward a firm where there are other black lawyers. See Ed Cray, Blacks and Browns in Blue-Chip Firms, CAL. LAW., Oct. 1984, at 35, 36 (quoting Stanford's placement director as stating, "Students look to see the NALP [National Association for Law Placement] breakdown of statistics. If no minorities are represented in a firm, they ask themseIves 'why,' and then 'why not."). We return to the role that black lawyers can play as possible "change agents" in Part IV. See infra notes 398-401 and accompanying text. The phrase "change agents" comes from Menkel-Meadow, supra note 12.

172. See Galanter \& Palay, supra note 24, at 24 .

173. See SMIGEL, supra note 13, at 37 (noting that firms wanted "lawyers who are Nordic, have pleasing personalities and 'clean-cut' appearances, are graduates of the 'right' schools, have the 'right' social background and experience in the affairs of the world, and are endowed with tremendous stamina"). The group most obviously disadvantaged by these additional criteria were Jews, who, despite their superstar academic credentials, were virtually excluded from most corporate firms until the late 1960s. See Galanter \& Palay, supra note 24, at 25. Indeed, as Paul Cravatli noted in a famous speech to Harvard law students, law firms did not particularly value brilliance at all:

Briliant intellectual powers are not essential. Too much imagination, too much wit, too great cleverness, too facile fluency, if not leavened by a sound sense of proportion are quite as likely to impede success as to promote it. The best clients are apt to be afraid of those qualities. They want as their counsel a man who is primarily honest, safe, sound and steady,

2 Robert T. Swaine, The Cravath Firmi and Its Predecessors 1819-1948, at 266 (1948).

174. See Knapp \& Grover, supra note 6, at 302.

175. See GALANTER \& PALAY, supra note 24, at 57 (noting that "recruitment las become more competitive and more meritocratic, leading to changes in the social composition of the new recruits").

176. See Richard D. Kahlenberg, Broken Contract: A Memolr of Harvard Law ScHool 94 (1992) (reporting that a Harvard Law School placement official "told Calvin Trillin that 
ver, every firm now claims that it screens for the "most qualified" applicants regardless of race, gender, or religion-applicants who have the potential to become partners in the firm.

Yet when we look closely at the hiring process, we are confronted with an apparent paradox: notwithstanding the vast sums that firms spend annually on recruiting, they collect little information about a law student's actual substantive legal knowledge or skills, and the information that they do acquire on these issues is generally ignored. In this Section, we argue that these seemingly paradoxical practices in fact constitute a consistent and rational response to the institutional realities of elite firm practice and the benefits firms expect to receive from recruiting. These practices, however, also systematically disadvantage black applicants.

\section{The Process}

Law firm hiring typically consists of three stages: the on-campus interview, the call-back interview, and (for first and second year students) a summer internship. ${ }^{177}$ What is striking about the first two phases is how little they have to do with the applicant's substantive knowledge or skills.

Initial interviews are primarily a function of student interest. ${ }^{178}$ The interview consists of a brief twenty-minute discussion with a single lawyer (often an associate). Although the interviewer has access to the candidate's resume (including his transcript) prior to the interview, ${ }^{179}$ it is rare for an interviewer to ask questions designed to test what the applicant has learned in law school. ${ }^{180}$ Instead, this brief encounter is taken

the large firms spend as much money in recruitment-travel, hotels, receptions, summer-clerk perks, and forgone billable hours-as the law school's annual budget").

177. See id. at 94-95 (describing the interview process for Harvard law students); David Eaves et al., Gender, Ethnicity and Grades: Empirical Evidence of Discrimination in Law-Firm Interviews, 7 LAW \& INEQ. J. 189, 192 (1989) (describing the interview process for UCLA Law School students); INSIDER's GUIDE, supra note 147, at 13-16 (describing the interview process). Third-year students with judicial clerkships also frequently work as summer associates.

178. At most elite schools, employers are required to interview every student who applies for an interview and receives a slot through a lottery system in which students rank firms according to the strength of their intcrest. See Granfield, supra note 128, at 134; Eaves et al., supra note 177, at 192 (describing a similar system at UCLA). At many non-elite schools, firms decide whom to interview on the basis of the resumes they receive, or in many cases, skip the on-campus interviewing process altogether.

179. Whethcr the interviewer actually looks at the resume before the interview is less certain. Anecdotal testimony over the years by both interviewers and interviewees suggests that at least on some occasions they do not. See Stewart Yerton, Scenes from the Recruiting Front: The Linvs of Supply and Demand Are Making Law Students at UVA Nervous, AM. Law., Nov. 1993, at 60, 63 (quoting a University of Virginia law student's belief that an interviewer from New York's Hughes, Hubbard \& Reed did not read his resume before the interview).

180. See GRANFIELD, supra note 128 , at 136 (reporting that "[r]ecruiters ... rarely pose questions to students that test their legal knowledge" and quoting a second year Harvard Law student 
up almost entirely by a discussion of the applicant's general interests, background and experience, and whatever questions the applicant has about the firm. ${ }^{181}$ Interviewers frequently conduct as many as ten to fifteen of these sessions in a day. Finally, firms rarely supplement the information they receive from resumes and interviews with other information (e.g., writing samples, faculty recommendations) that might offer insight into an applicant's quality. ${ }^{182}$

Firms therefore make call-back decisions based on the information that appears on an applicant's resume and transcript and a single lawyer's assessment of the candidate's general promise and personality. Not surprisingly, grades and other traditional indicia of academic accomplishment (such as law review membership) figure prominently in this calculation. ${ }^{183}$ Even these traditional indicia of merit, however, are not treated as seriously as they might be. Rather than ranking candidates by academic standing, firms tend to use loose grade cutoffs pegged to the academic standing of the applicant's school. ${ }^{184}$ Within these rough and malleable ranges, the primary criterion is whether the candidate will "fit in" to the firm's culture.

More often than not, call-back interviews merely repeat this pattern. Although applicants see more lawyers, the content of these discussions mirrors what transpires on campus: candidates are asked almost no sub-

as saying "I prepared myself for a technical discussion. I thought they would ask me about strict liability or something. They didn't ask me any legal type of questions"). By way of comparison, consulting firms routinely ask applicants to analyze a typical business school case during the interview. Interview with Roger Ferguson, Principal at McKenzie and Co.

181. The following comments are typical of statements in the Insider's Guide:

[When interviewing at New York's Simpson Thatcher,] "be as personable and engaging as possible"... . The best way to fit into the firm's culture is to be "relaxed and charming," counseled one [firm lawyer]. "Emphasize other interests besides the law," recommended another. "Don't emphasize money" commented one contact and don't be "anal or pushy."

INSIDER's GuIDE, supra note 147, at 422. "While [New York's Fried Frank] emphasizes high academic achievement, one person stated that 'you have to have something unusual on your resume to get a call-back. Bungee jumping or skydiving helps, but so does being an opera singer or enjoying math problems." Id. at 362; see also Paul F. Buller \& Caryn L. Beck-Dudley, Performance, Policies and Personnel: How Does Your Firm Do It?, A.B.A. J., Oct. 1990, at 94, 94 (reporting that personal characteristics are among the most important traits recruiters look for when interviewing candidates).

182. For example, only six of the approximately 600 firms interviewing at Harvard Law School in 1994 asked candidates to bring a writing sample to their initial interview. See Harvard LAw School Office of Career Services, Interviewing Calender (1994).

183. See Eaves et al., supra note 177 , at $197-98$ (demonstrating that high grades and law review membership are both strong predictors of whether a UCLA student is likely to get a call-back interview).

184. See INSIDER's GuIDE, supra note 147, at 230 (reporting that Houston's Baker \& Botts "looks at people in the top quarter of their class at the University of Texas, the top five percent of their class at the University of Houston, and the top half of their classes at national law schools such as Columbia, Harvard, Stanford, the University of Chicago, the University of Virginia, and Yale"). Firms pay more attention to the perceived quality of the institution from which a candidate is graduating than to the content of the courses on an applicant's resume, rarely taking note of whether the courses a student has taken are likely to prepare him or her for corporate law practice. 
stantive questions and the primary issue is whether the applicant will "fit in." 185 As a result, at some firms, call-back interviews are almost a pro forma process in which most candidates receive summer offers unless they affirmatively demonstrate that they are not likely to fit in to the firm's culture. ${ }^{186}$ Even those firms that use call-back interviews as a significant screening device, however, do so primarily on the basis of personality and fit.

This lack of attention to quality in the first two phases of the recruiting process might be understandable if firms relied on their summer programs to monitor and evaluate summer associates before extending offers of permanent employment. But they do not. Although firms collect information about their summer associates, ${ }^{187}$ this information rarely influences hiring decisions. Figure 2 shows the average summer associate offer rates for large firms in Baltimore, Atlanta, San Francisco, New York, and Chicago. ${ }^{188}$ With the exception of Balti-

185. The following comments about three Boston firms are typical: "[At Bingham, Dana \& Gould,] [c]all-back interviews, which usually involve meeting four attorneys, were described as 'pleasant chats.' One source reported that 'they are just trying to see if you would fit in and whether you have a personality." Id. at 79.

[At Goulston \& Storrs,] [c]allback interviews involve meeting with about four attorneys and going to lunch with a few more. Candidates who are invited to the firm for a callback are presumed to be academically qualified to work at Goulston, and the major purpose of the interview is to assess whether the applicant "fits in" with the firm culture. Attorneys ask very few "substantive legal questions" in the interviews, our contacts told us. Id. at 98 .

[At Nutter, McClennon \& Fish,] [a]t the call-back, candidates usually interview with a senior partner, the hiring partner, and two associates. They then go out to lunch with two associates. Most call-back interviews are conversational. No one we interviewed was asked substantive legal questions. According to one insider, the partners make the hiring decisions, and they are mainly "looking to see if you fit" into the firm culture. Id. at 111 .

186. As associates at Boston's Goodwin, Procter \& Hoar report:

The interview is "more an opportunity for you to find out inore about the firm," said one suceessful applicant. If you make it to the callback stage, "there is a presumption in your favor" that you will be hired, commented another. "They just want to make sure they can work with you."

Id. at 95 .

187. This was not always the case. In the go-go days of the 1970 s and 1980 s, summer programs were characterized by tickets to ball games and outings to partners' houses rather than by work on serious projects. During the recession, programs were tightened up. See Caroline V. Clarke, Summer of Fear, AM. LAw., Oct. 1991, supp. 6, 8; Amy Stevens, Vacation Is Over for Summer Associates as Law Firms Reduce Perks, Add Work, WALl St. J., June 10, 1994, at B1 (describing how, as a result of the recession, firms have reduced expenses on summer programs). Nevertheless, according to many reports, social functions still play an important part in the summer experience. See INSIDER's GUIDE, supra note 147, at 27 (describing Alston \& Bird's summer program as "really social" and "summer camp-like"); see also Rick Hampson, Summer law Associates Still Want the Perks; Survey Finds Food a Concern of Many Students, Legal INTElligencer, Nov. 3, 1993, at 3 (calling summer programs "prenuptial honeymoons"); Saundra Torry, In Frugal '90s, Firms Still Pamper Summer Associates, WASH. PoST, July 4, 1994, at 7 (describing relatively lavisb current programs).

188. Appendix, Figure 2. 
more, ${ }^{189}$ all of these rates exceed $70 \%$, with firms in the most desirable cities hovering around $90 \%$. Many of the country's most prestigious firms grant offers to all of their summer associates. ${ }^{190}$ Moreover, like assoicate salaries, these percentages have remained remarkably consistent over time, even during the recession when firms were laying off "permanent" associates.

Elite firm hiring, therefore, is "meritocratic" only to the extent that the few highly visible signals a firm can observe at the initial oncampus interview-the most important factor in determining whether a candidate receives a permanent job offer-are accurate predictors of which law students will make the best lawyers. As noted previously, although the signals are loosely correlated with both substantive legal knowledge and important personal characteristics such as intelligence and effort, they are notoriously noisy when it comes to predicting future performance as a lawyer (as opposed to future performance as a law student). ${ }^{191}$ Why do law firms spend tens of thousands of dollars each year on a process that provides such an imperfect measure of the quality of their future employees? The answer lies in the firm's bottom line.

\section{Signals and Signaling: Stocking the Pipeline and Protecting the Franchise}

Elite law firms have two primary objectives in hiring. The first is to stock the pipeline with associates capable of competently filling the firm's labor needs. The second is to signal the firm's quality to clients, competitors, and potential recruits.

Stocking the pipeline requires hiring associates who can diligently perform routine tasks with a minimum of supervision. Although this is also the pool from which the firm will select most of its senior associates and partners, for the reasons stated in Part II, it is not necessary that all (or even most) of its entering associates be of "partnership quality." Moreover, since whether any particular associate actually develops the higher order legal skills needed by senior associates and partners depends in large part on whether she receives the Royal Jelly of firm

189. The lower offer rate in Baltimore may be due to the fact that these firms are less leveraged and have higher partnership rates than are typical in the other four cities. Thus, according to data from the Insider's Guide, the ratio of associates to partners in Baltimore was .83:1, as compared to 1,1:1 in San Francisco/Palo Alto and 1.9:1 in New York. See INSIDER's Guide, supra note 147, at 53, 509,305 . Given these structural differences, these firms are likely to collect more information on the actual quality of their summer associates (because of the relative ease of direct monitoring) and have a greater incentive to use this information (since the smallcr number of associates makes each one more valuable).

190. See INSIDER's GuIDE, supra note 147, at 338, 332, 398, 428 (reporting that Cravath; Cleary, Gottlieb; Paul, Weiss; and Sulhvan \& Cromwell all gave offers to nearly $100 \%$ of their summer associates in 1993).

191. See supra notes $98-102$ and accompanying text. 
training, it is more efficient for the firm to defer looking for those likely to fill these roles until the first phases of the tournament rather than spending resources refining their predictions about future potential. It is the need for foot-soldiers, not generals, that drives the hiring process.

The high wages and benefits associated with working at an elite firm ensures that firms will be deluged with applicants who meet the basic requirements for being good foot-soldiers. The pyramidal structure of elite firms ensures that much of the work done by entering associates will be routine and redundant, calling for none of the discretionary judgment at the heart of good lawyering. Nor is it necessary that the lawyers who are assigned these tasks be exceptionally smart or well trained. Although there may be advantages to having a person with superstar intelligence keep track of documents, draft letters and memoranda to the file, respond to discovery requests, and do routine legal research, these benefits pale in relation to the value of having an associate who is careful, well organized, pays attention to detail, and has a high boredom threshold. These qualities are neither taught directly in law school nor especially rewarded in the grading process. The fact that many firms have recently turned a substantial amount of this routine work over to paralegals with no law school training, is potent proof that the range of people who can perform this work competently is larger than those with traditional signals such as an elite law school education or law review membership. ${ }^{192}$

As most partners would be quick to point out, however, this description of the work of an entering associate only tells part of the story. In addition to performing routine and undemanding tasks, new associates are sometimes called upon to answer difficult legal or factual questions. Moreover, these issues can arise unexpectedly, embedded in problems that otherwise appear to be routine. Given this reality, the hypothetical partner would argue, firms need to hire associates who can recognize sophisticated legal and factual issues when they arise even if they have not yet developed the higher order skills and dispositions that are ultimately necessary to resolve these questions. Consequently, the partner would conclude, the range of applicants who are actually qualified to be associates at an elite corporate firm is much smaller than might at first appear. In addition, since legal knowledge and basic personal qualities such as intelligence and hard work are the key variables in this story, it is rational for firms to rely on traditional credentials like law school status and high grades as proxies for the characteristics they seek.

This argument trades on a confusion between "average" and "ideal." Law firms, like all other employers, would prefer to have em-

192. On the growth in the number of paralegals, see GaLANTER \& PALAY, supra note 24 , at 65 . 
ployees who could quickly and proficiently handle every contingency that might arise in the performance of their duties. To the extent firms can identify applicants who, because of either their legal skills or their other personal characteristics, are likely to be able to recognize complex legal issues and take appropriate action with relatively little supervision, they will prefer these candidates to those who do not have these abilities. Assuming arguendo that superstar academic performance (e.g., graduating at the top of the class at an elite law school) is even loosely correlated with these abilities - a reasonable, although as we have indicated, largely unproven assumption-a firm might choose to hire only those who have this qualification. ${ }^{193}$

In today's legal marketplace, however, this strategy is no longer a realistic option. Given the explosion in the size and number of large firms competing for the pool of superstar graduates from elite law schools, not even the most prestigious and high paying firms can limit their recruiting in this fashion. ${ }^{194}$ Instead, firms must also hire from the much larger pool of average candidates. These candidates present an array of mixed signals: for example, average grades at high status schools or good grades at lower status schools. Unlike the small number of academic superstars, the claim that these candidates can be ranked in terms of their actual quality by referring to a few easily observable signals lacks credibility. To take just one example, to say that where a student goes to law school is an accurate proxy of either that student's legal skill or native intelligence ignores the many variables that can affect that choice. As a result, it is doubtful that many would claim that a student in the middle of her class at Harvard is inevitably better prepared or "smarter" in any way that plausibly correlates with job performance as an associate at an elite firm than a student at the top of her class at Boston University who put herself through law school by working two jobs. Yet, this kind of judgment is exactly what would be required to justify on merit grounds the enormous weight that is placed on the status of a candidate's law school in the recruiting process.

This is not to say that firms could not make more nuanced judgments about the quality of these applicants if they were so inclined. Indeed, if firms were prepared to dig deeper, perhaps by conducting indepth interviews designed to reveal substantive knowledge and problem solving skills, or by doing an extensive investigation into the candidates' academic and work experience, they might discover that applicants

193. It is important to note that this supposition is belied by the fact that firms counted social background at least as highly as academic standing during a period when their hiring needs were much smaller than they are today. See supra note 173 .

194. See Bernstein, supra note 30, at 20 (reporting that the yearly demand for associates by the top 250 firms far exceeds the number of students in the top $50 \%$ of the graduating classes of the top 20 law schools). 
whose traditional signals were on the margin actually have better skills than those whose signals were at, or near, the top. Certainly, any review of the "best" lawyers in America would reveal several who do not have the kind of traditional credentials that most corporate firms look for. ${ }^{195}$

Firms, however, have little incentive to expend the added resources it would take to reach such fine-tuned judgments. The average workers that they select on the basis of the limited information they collect are perfectly capable of performing the average jobs to which they are assigned. To be sure, as the hypothetical partner discussed above would insist, the fact that firms make their hiring decisions in this manner means that sometimes an associate whose actual abilities are in the low end of the average range will fail to see a complex legal issue embedded in an otherwise straightforward discovery problem that would have been spotted by the associate the firm could have hired whose skills were in the high part of the average distribution. So long as the firm suffers relatively few negative consequences as a result of such occurrences (e.g., because the issue is never discovered by either the client or the client's adversary, or because the firm is able to rectify-or cover upthe mistake), it is rational for employers to take this risk rather than incur the cost of reviewing the actual abilities of each applicant in the average range.

Although this explains why firms pay little attention to a candidate's substantive legal skills, the question remains why firms invest such large sums in recruiting and why they rely on a mixture of objective and subjective criteria. Given our conviction that there are a large number of lawyers who could competently perform the work of the average corporate law firm associate, we might expect firms to recruit at a large number of elite and second-tier law schools, but to expend relatively little energy choosing among average applicants. Skadden Arps, for example, used this strategy quite effectively during the 1980 s when it hired large numbers of associates, including many from "secondtier" law schools such as Fordham, and then let these new recruits fight it out for partnership..$^{196}$ Indeed, since we theorize that associates are motivated in part by the fear of losing their high-paying jobs, one would think that, other things being equal, a firm would prefer to hire a law student from Fordham as opposed to one from Yale, since elite law firm jobs are scarcer for Fordham graduates.

Elite firms, however, gain more from recruiting than simply getting lawyers to do the work of the firm. They also use recruiting as a means of signaling the firm's quality to potential clients, competitors, and po-

195. For example, only two of the lawyers in O.J. Simpson's famous "Dream Team," Alan Dershowitz and Barry Scheck, graduated from elite law schools.

196. See CAPLAN, supra note 67 , at $157,159$. 
tential recruits. One of the traditional ways that law firms have signaled their quality to clients is by the number of former Supreme Court law clerks, law review members, and other elite law school graduates they employ. ${ }^{197}$ Over and above their usefulness as a business-getting device, recruits from elite law schools also increase a firm's status among its peers. ${ }^{198}$ Indeed, even individual lawyers within firms are likely to be biased in favor of graduates from their alma mater, since hiring these students both validates the partner's own credentials and increases his standing with his fellow alumni. ${ }^{199}$ Given the restrictive hiring practices followed by most firms during the "golden age," this bias further increases the demand for elite law school graduates. As a result, firms overinvest in competing for elite law school graduates and for those with "prestige" signals. ${ }^{200}$

In order to win the competition for these coveted recruits, however, firms must both credibly signal their quality to these applicants and appear to treat those who do apply fairly. This helps to explain the division of the recruiting process into a "visible" stage, in which firms review a candidate's objective credentials, and an "invisible" stage, dominated by subjective judgments about personality and fit. At the visible stage, firms signal their quality by appearing to rely on objective criteria (law school status, law review membership, and grades) that are easily accessible and rankable by law students. Those firms that can be the most restrictive on these criteria gain a reputation as being the "best" firms, and therefore attract the "best" potential recruits. If a firm is seen as acting unfairly at this visible stage (for example, by refusing to interview black candidates whose credentials are clearly superior to those of white candidates who are interviewed), the firm's reputation among law students will suffer. ${ }^{201}$

197. On the connection between a law firm's status and the educational background of its lawyers, see ABEL, supra note 38, at 206; NELSON, supra note 24, at 66 .

198. See ABEL, supra note 38, at 217-18 (describing the tendency of prestigious schools' graduates to be channeled to larger firms and local schools to produce solo practitioners).

199. See GRANFIELD, supra note 128 , at 135 (discussing the importance of the fact that "[m]any interviewers are former [Harvard] graduates demonstrating their loyalty to the institution"); INSIDER's GuIDE, supra note 147, at 362 (quoting an associate at Fried Frank who reported, "it's harder to get an offer if you are from a local school; though if you are from Yale, you will definitely get an offer bccause Yalies stick together").

200. The experience of Skadden Arps is again instructive. Lincoln Caplan reports that despite unparalleled financial success during the 1980 s, Skadden partners still longed for the status and respectability of its more established "white shoe" Wall Street competitors. To achieve this goal, Skadden invested heavily in recruiting elite law school graduates, setting records for the lavishness of its recruiting events and summer program. These efforts eventually bore fruit. As a result, Skadden's hiring patterns now look like those of its competitors. See generally CAPLAN, supra note 67.

201. As we explain below, discriminating in this fashion might also result in legal liability. 
At the invisible stage, however, firms no longer have to worry about this problem. Law students realize that the objective criteria used at the visible stage do not account for all of the variables on which a rational firm might want to make its employment decisions. They therefore accept the fact that firms should inquire more deeply into the qualities of candidates, particularly where the objective credentials of two or more applicants are functionally indistinguishable. Because this process occurs out of sight (for example, in call-back interviews), firms have less of an incentive to base their decisions on objective criteria. Thus, rather than reviewing writing samples or asking substantive questions designed to test legal knowledge and analytic skill, firms focus on assessing whether the applicant will fit in to the firm's culture. Although this assessment is undoubtedly an important part of any hiring process, firms are free to emphasize issues of personality and fit over arguably more relevant determinations about writing ability and analytic skill because the invisibility of the call-back stage makes it unlikely that the firm's actions in this sphere will undermine its overall reputation and ranking among law students.

Taken together, these costs and benefits unravel the paradox presented at the beginning of this Section. Although the objective signals firms employ at the visible stage are a highly imperfect measure of an applicant's potential, they do a reasonably good job of winnowing down the pool and, more importantly, they give clients, competitors, and law students an accessible and rankable method of rating firms. Given that this process will produce a large number of average applicants who could perform the job effectively, firms are free to rely on subjective criteria to make the final selections at the invisible stage while at the same time lavishly pursuing the few superstars upon whom the firm's prestige in the recruiting market for elite law school graduates ultimately rests.

\section{Race and Recruiting}

In the absence of countervailing policies, ${ }^{202}$ we predict that blacks will be disadvantaged by recruiting practices such as those described above in two ways. First, since firms have little incentive to investigate the actual quality of their potential employees, average blacks are less likely to be hired than average whites. Second, because black applicants are aware of their reduced employment prospects, they have an incentive to adopt human capital strategies that, on average, decrease their overall prospects for success. The following examination of how blacks have fared in the recruiting process supports both predictions.

202. At this stage we are interested in exploring what happens when firms make no affirmative efforts to hire black lawyers. 
The fact that firms rely on a few objective signals to identify qualified applicants at the visible stage and reserve the right to go behind these credentials to make judgments about personality and fit at the invisible stage doubly disadvantages black applicants. As others have documented, by relying on sorting devices such as law school status, grades, and law review membership, firms systematically exclude the majority of black applicants, who do not have these standard signals. ${ }^{203}$ Thus, although blacks may be more likely to attend higher status law schools than whites, ${ }^{204}$ the schools with the largest black populations are not ones from which large firms typically recruit. ${ }^{205}$ Even black students with superstar credentials from lower status schools have little or no chance of being hired by a large firm. ${ }^{206}$ Those blacks who do attend elite schools face recognized barriers (e.g., poor primary and secondary school education, diminished expectations, hostile environments, and part-time work) to performing well in the classroom or in extracurricular activities such as law review. ${ }^{207}$ Given these added pressures, it is plausible, as both conservative critics of affirmative action in elite schools and supporters of historically black schools frequently assert, that some black students who are currently admitted to elite schools would be more successful (both academically and personally) if they

203. See Lugo, supra note 56, at 624-30 (arguing that law firm hiring criteria are racially discriminatory). Needless to say, these criteria also exclude the vast majority of white applicants, many of whom are also within the average range in terms of their skills to be average corporate associates. The percentage of whites remaining in the pool, as defined by these criteria, however, is disproportionally larger than the corresponding percentage of blacks vis-a-vis their percentage in law schools. This is simply another example of how practices that affect all workers disproportionately disadvantage blacks.

204. Cf. Gene Kratz, Less Diversity at B-Schools, Bus. WK., Apr. 26, 1996, at 26. Given that blacks generally score lower on the LSAT than whites, this upward trend in part reflects greater affirmative efforts on the part of elite schools. See Russell L. Jones, The Legal Profession: Can Minorities Succeed?, 12 T. MARshall L. REv. 347, 349 (1987) (discussing lower LSAT scores of black applicants). We retum to affirmative action by elite law schools below.

205. See Richard Connelly, Preconceived Notions: Recruiters Pigeonhole TSU Graduates, Leaving Top Students in the Cold, TEx. LAw., May 17, 1993, at S-1 (noting that "[f]irms that talk grandly about increasing their minority hiring don't look to do it at [Texas Southem University]'s law school, where half of the 587 students are African-American"); Jensen, supra note 12, at 29 (arguing that firms should include minority-dominated law schools in addition to Howard University in their recruiting efforts).

206. See Connelly, supra note 205 , at S-1. Connelly describes a TSU student's inability to get a single offer from a large firm in Texas despite the fact that she graduated "magna cum laude, second in her class, [was a] law review editor, and ... clerk[ed] at the Texas Supreme Court." As one hiring partner explained, "we usually can fill our needs at the top schools." Id.

207. See Jensen, supra note 12, at 29 (quoting Lujuana Treadwell, President of the National Association for Law Placement and director of recruitment for Berkeley's Boalt Hall, as stating that "minority students are more likely to need to be employed during law school or choose to be active in student organizations, thereby making it more unlikely that they might meet the big firm rigid employment criteria"). See also, FEAGIN AND SIKES, supra note 46, at 78-129 (describing the many obstacles that black students face when seeking a good education). 
did not attend these academic institutions. ${ }^{208}$ However, given the nearly dispositive role that the status of an applicant's law school plays in the recruiting process, black students who want to have the option of working at an elite firm have little incentive to choose this option. Those who have problems at elite institutions, however, risk being branded as unacceptable by prospective employers.

Indeed, to the extent that firms make hiring decisions based on signals such as grade point averages, as opposed to the substantive content of the courses a student has taken or other indicia of the skills that the candidate has acquired in law school, black applicants have an incentive to structure their education so as to maximize the former at the expense of the latter. For example, it is widely believed that certain advanced corporate courses, such as corporate tax, commercial transactions, and securities regulation, are among the most difficult in the law school curriculum, particularly for students who have little or no prior background (academic or otherwise) in these areas. If this is true, and if black students are less likely to have the kind of background knowledge that increases their chance of doing well in these subjects, ${ }^{209}$ then they will have an incentive to avoid these difficult, but potentially useful, courses in favor of classes where they stand a better chance of getting a good grade. ${ }^{210}$

208. See FEAGIN AND SiKES, supra note 46 , at $130-32$ (reporting that many black students feel they would be more successful at black educational institutions).

209. Empirical and anecdotal evidence suggests that this may be the case. Given that less than $40 \%$ of black households qualify as middle class (as opposed to $70 \%$ for whites) it is likely that African American law students tend to come from more disadvantaged socio-economic backgrounds than their white classmates. See Michael Dawson, Behind the Mule, Race and Class in AfRICAN AMERICAN Politics 29 (1994). Affirmative action programs that combine race and class will reinforce this tendency. Moreover, as Dawson goes on to point out, even middle-class blacks are less likely to be connected either through employment or wealth accumulation to the upper echelon of the private sector that is the focus of the kind of high-level corporate courses we are discussing. See id. at 29-33 (arguing that middle-class blacks are less likely to work in the private sector than whites are and have accumulated substantially less housebold wealth than middle-class whites). Anecdotally, many black students have told Professor Wilkins over the years that their lack of knowledge or experience witb the problems discussed in advanced corporate courses is one reason why they believe that they will find these courses particularly difficult. Even if black students are mistaken about the importance of this kind of background knowledge, if they believe it to be true the adverse effects described in text will persist until this misperception is corrected.

210. Two pieces of anecdotal data collected by Professor Wilkins point in this direction. First, Harvard Law School faculty who teach upper-level courses in corporations, securities and tax report that relatively few black students take these offerings. Second, several black students reportcd that the reputed difficulty of these courses and concerns that a low grade would diminish their overall employment prospects has discouraged them or their African American classmates from enrolling in these courses. Althougb we contend that most lawyering skills are learned on the job, associates who come in with more knowledge about the legal issues that are relevant to their chosen area of practice will have lower start-up costs in completing the first few assignments, and therefore, stand a better chance of signaling that they are good prospects for the training track. It is precisely these potentially valuable job-related skills. however, that the current recruiting process undervalues. 
At the same time, the emphasis on personality and fit at the invisible stage can disadvantage black applicants with traditional signals. Like the general population from which they come, law firm interviewers hold a variety of conscious and unconscious stereotypes about black law students. Although incidents such as the 1989 debacle involving a partner from Chicago's Baker \& McKenzie, who demanded to know a black female applicant's high school grade point average and how she would react to being called a "black bitch" or "nigger" are undoubtedly rare, ${ }^{211}$ they underscore the fact that outright prejudice against blacks still exists at elite firms. Sexual harassment and other forms of overt discrimination against women mean that black women face a double burden..$^{212}$ Such outright prejudice is no longer condoned and, when detected, is sanctioned. ${ }^{213}$ The subtler forms of bias or preferencing, however, are more pervasive and difficult to pin down.

For example, a consistent line of empirical research demonstrates that when whites evaluate blacks, they frequently attribute negative acts "to personal disposition, while positive acts are discounted as the product of luck or special circumstances."214 Empirical and anecdotal accounts of the experiences of black and white applicants in the interviewing process confirm that this phenomenon negatively affects employment opportunities for black lawyers. Pervasive myths about black intellectual inferiority combined with lower average levels of achievement in areas such as grades and test scores tend to make white interviewers question the credentials of blacks more than those of

211. See Lugo, supra note 56, at $626 \mathrm{n} .48$ (describing the incident). Baker and McKenzie was temporarily banned from recruiting at several law schools because of the incident. Jensen, supra note 12 , at 29 .

212. The fact that King and Spalding proposed holding a "wet t-shirt contest" for female summer associates-to be staged while the firm had a sex discrimination lawsuit pending against itdemonstrates just how difficult these barriers will be to overcome. Upon sober reflection, the firm decided to hold a swimsuit competition instead. See Harrington, supra note 168 at 36,37 . For a discussion of the double burden faced by black women, see generally Kimberle Crenshaw, Mapping the Margins: Intersectionality, Identity Politics, and Violence Against Women of Color, 43 STAN. L REv. 1241 (1991).

213. The elassic example is that of King and Spalding, see supra note 212, which today has reformed matters so far that a 1995 study by the Harvard Women's Law Association rated it as the best of flfty-seven elite law firms for women lawyers. John E. Morris, King \& Spalding Lands On Top, AM. LAw., Jan.-Feb. 1996, at 18.

214. Selmi, supra note 49, at 1285 (deseribing perception of outgroup behavior generally); see also James Jones, Piercing the Veil: Bi-cultural Strategies for Coping with Prejudice and Racism, in Opening Doors: Perspectives on Race Rezations in Contemporary America, 179, 195 (Harry J. Knopke et al. eds., 1991) (noting that "the basic tendency for human beings [is] to make social eategorical judgments leading to an ingroup preference"); George I. Whitehead, III et al., The Effect of Subject's Race and Other's Race on Judgments of Causality for Success and Failure, $50 \mathrm{~J}$. Personality 193, 200 (1982) (noting a study finding "that the failure of another is attributed more to the lack of ability when the other is racially dissimilar than when he is similar"). 
whites. ${ }^{215}$ In addition, interviewers generally expect to feel less comfortable when interviewing blacks. ${ }^{216}$ Similarly, as we note above, interviewers frequently tend to believe that blacks are "uninterested" in corporate practice. ${ }^{217}$ Black women are particularly vulnerable to this "lack of interest" stereotype in light of the persistent belief that women place family responsibilities above professional commitments. ${ }^{218}$

Given that firms collect little information about an applicant's actual skills, it is not surprising that interviewers are affected by such stereotypes. Since race is costless to observe, it provides a convenient mechanism, much like "personality" and "fit," for sorting applicants. The fact that it does not correlate to the ability to practice law is irrelevant from the point of view of firm profits, so long as the only consequence of error is that average whites are hired in the place of average blacks.

Moreover, blacks on average have less access to influential contacts and other informal networks that allow some other candidates to bypass the formal screening requirements. Consider the experiences of two students at the University of Virginia law school reported in a recent story in the American Lawyer. ${ }^{219}$ Both students-Jay, a white male and Jennifer, a black female-had grades in the B-minus/C range. As a result, although both have strong personal qualities and extra-curricular activities, neither was able to secure an interview with a large firm in

215. See Emily Campbell \& Alan J. Tompkins, Gender, Race, Grades and Law Review Membership as Factors in Law Review Hiring Decisions: An Empirical Study, 18 J. ConTEMP. L. 211, 241 (1992) (reporting that with resumes of candidates in hand, law firms were more likely to request more information from a black candidate in the top $30 \%$ of his class than from a white candidate similarly situated).

216. See Arnie Kanter, Hiring of Minorities Takes Thought, NaT'L L.J., Apr. 25, 1988, at 19 (quoting a hiring partner from a major firm as stating, "When 1 go into an interview with a minority, 1 just want to get out of the thing alive"). As Kanter notes, such feelings are likely to make it more difficult for the minority interviewee to make a "good impression on the interviewer"-a major determinant of whether the candidate will receive a job offer. Id.; see also Steven Keeva, Unequal Partners: It's Tough at the Top for Minority Lawyers, A.B.A. J., Feb. 1993, at 50, 52 (arguing that whites feel less comfortable with black lawyers).

217. See supra note 39 and accompanying text.

218. See HARRINGTON, supra note 168 at 19 (reporting that women must frequently justify their commitment to law practice to law firm recruiters); Marie T. Huxter, Survey of Employment Opportunities for Articling Students and Graduates of the Bar Admission Course in Ontario, 15 LAw SOC'Y GAZETTE 169, 189-90 (reporting that women lawyers in Canada are frequently askcd questions such as "if 1 intended to make a career out of practising law or planned to marry and have babies"). The fact that studies of women in the workplace have repeatedly demonstrated that women generally have higher levels of commitment to their jobs than men has so far failed to eradicate these stereotypical beliefs. See, e.g., HAGAN \& KAY, supra note 166, at 185 (reporting that their study of women lawyers in Ontario did not confirm that women were less committed to their jobs than men and that "men accumulated more hourly billings than women through the use of hierarchical positions in firms, not because women gave up hours as a result of competitive demands or comparative specializations that involved investments in the family").

219. See Yerton, supra note 179 , at 60,61 . 
their respective cities of choice (Richmond for Jay, Atlanta for Jennifer) through the normal UVA process. ${ }^{220}$ Nevertheless, by the end of the story, Jay is headed for three promising interviews with Richmond firms while Jennifer has no such prospects. Why? Because Jay was able to call a friend "with considerable influence in Richmond."221 Jennifer had no similar connections. 222

This story also highlights another way in which the interplay between formal and informal criteria disadvantages blacks. Although her grades were uninspiring, Jennifer was a member of the UVA law review and had worked for two small firms during prior summers, including one in Atlanta. Law review membership and prior work experience are the kind of easily observable signals upon which firms generally rely, but Jennifer appears to be getting less mileage out of these signals than one might expect. ${ }^{223}$ Although there may be many explanations for this result, ${ }^{224}$ one possible explanation is that even traditional signals such as good grades and law review membership count less for blacks than they do for whites. ${ }^{225}$

220. Unlike many of its elite competitors, UVA allows interviewers to pre-screen resumes and to interview only selected candidates. Id. at 61 .

221. Id.

222. As she pointedly observes: "The reality is, there aren't that many black men and women [at large firms] who could give jobs to their kids or friends or whatever." Id. at 62.

223. Of course we would not expect Jennifer to get the same benefit from being on the law review as someone with an " $A$ " average. However, to the extent that firms view law review membership as an independent signal, it should have value, even for those with low grades. Thus, Jennifer, who has this signal, should do better than Jay, who does not. We recognize, however, that firms may have discounted Jennifer's law review signal because they believed that the law review has an affirmative action policy. Unless they believed that this policy carried over to the work Jennifer did on the magazine, this signal still should have value. We return to affirmative action below.

224. For example, the article does not state whether Jennifer received an offer from the Atlanta firm where she clerked during the previous summer.

225. There is some empirical support for this proposition. For example, in their excellent study of gender differences among lawyers in large firms in Toronto, Professors Hagan and Kay found evidence that the "meritocratic criterion [of good grades] is applied more stringently in the selection of women than men." HAGAN \& KAY, supra note 166, at 66; Susan Duncan, What Women Need to Make It to the Top, AM. LAw. (Supp.) Jan.-Feb. 1996, at 9 (arguing that it is more important for women than for men to be superstars). Similarly, Hagan and Kay found that personal characteristics such as having a "WASP" background were statistically beneficial to men but not to women. HAGAN \& KAY, supra note 166 , at 66 . Although not statistically significant because of the small sample size, a study of minority and non-minority students at UCLA Law School found that "even top G.P.A. minority students had lower success rates than non-minority students, and third-quartile minority students had less than half the success rate of non-minority students." Eaves et al., supra note 177, at 201. Interestingly, this same study found that women did significantly better in obtaining call-back interviews than men with similar grades and that this disparity was greatest when men interviewed women at the bottom of the class. Id. at 204-10. Whether this difference is due to "attraction between male lawyers and women" or "a reluctance by female lawyers to offer call-backs to other women," id. at 207, the data demonstrate how an interviewer's subjective biases or tastes affect a candidate's employment prospects. See also Jensen, supra note 12, at 29 ("Justice Archer of the Michigan Supreme Court claims that the large law firms-despite their claims to the contrary-reach 
Even black superstars can fall victim to this phenomenon. A firm does suffer an efficiency loss if it consistently fails to hire blacks who fall into the superstar category. ${ }^{226}$ Nevertheless, the bias against average blacks also makes it more difficult for black superstars to be regarded as such. Because employers know that blacks have an incentive to signal themselves as superstars when they are in fact average, and that this strategy (if successful) will be difficult to detect, firms have an incentive to discount indicia of accomplishment as false positives. Since hiring partners know that criteria such as grades are fuzzy, lawyers who are predisposed to believe that blacks are less likely to be superstars than whites can justify looking beyond the usual signals to reach a more subjective evaluation of the candidate's quality. Anecdotal evidence suggests that this occurs with some frequency. ${ }^{227}$ At a minimum, this possibility must be counted against the potential, documented by Stephen Carter, for whites, because of their diminished expectations of black performance to accord superstar status to average blacks because they are the "best black" in the group. 22

Together, the fact that firms prefer average whites over average blacks and the corresponding tendency for these employers to discount the credentials of blacks who signal themselves to be superstars make it harder for blacks to be hired by elite law firms. This state of affairs is self-perpetuating, since firms that substitute average whites for average

as deep as the top 60 percent of the class for white candidates but they select minority recruits from only the top 10 percent."); Deborah Holmes, Structural Causes of Dissatisfaction Among Large-Firm Attorneys: A Feminist Perspective, 12 WoMEN's RTs. L. REP. 9 (1990) (reporting that unattractive or overweight female candidates have a disproportionately difficult time finding jobs).

226. This helps to explain the common perception that blacks with superstar traditional credentials are heavily recruited. See, e.g., Schmidt, supra note 171, at $\$ 46$. Schmidt reports:

Major firms ... recruit law students in the top of their class at a select group of law schools, fostering fierce competition for the few minorities who meet the traditional description of the well-qualified associate.

"Like most of the big firms, we're hiring outstanding students and there is quite a competition [for minorities]," says Wiley, Rein name partner Richard Wiley.

Id. Although this is often described as a competition for "qualified" blacks, we believe that it is better understood as a search for black superstars. We return in Part IV to the potentially valuable effects of fostering a competition for black applicants.

227. For example, a former associate at a major Washington, D.C. law firm reports that a black Harvard graduate with an A-minus/B-plus grade point average was turned down for a summer associate position because firm partners felt that he had taken too many "easy courses." One partner even went so far as to suggest calling one of the applicant's professors to determine whether he really deserved the " $A$ " he received in the course. The informant reports that during her tenure on the hiring committee, no one inquired into the difficulty of courses taken by white candidates, let alone suggested calling a faculty member to look behind a grade. Interview with Professor Wilkins.

228. See Stephen L. Carter, Reflections of an Affirmative Action Baby 53-54 (1991). See generally, Charny and Gulati, supra note 9, at 22-23. This dynamic may have shifted over time. For example, Chief Judge Harry Edwards of the U.S. Court of Appeals for the District of Columbia Circuit is quoted in a recent article, as remarking: "Kids like my son face constant pressure. The assumption starting out is that they're affirmative action and that someone put them there, whereas the assumption with me was I must be smart as hell." Herman, supra note 17I, at 60 . 
blacks suffer no competitive disadvantage. Once we take into account the additional fact that the number of black lawyers already working in a particular firm is positively correlated with that firm's likelihood of hiring additional black attorneys, the chances of moving beyond this equilibrium seem daunting. ${ }^{229}$

Ironically, these structural features of the recruiting process also lead us to predict that the blacks who are hired will tend, on average, to be clustered in the superstar range..$^{230}$ In light of the rampant discrimination during the "golden age," it is not surprising that the few black lawyers who were hired during this period had superstar qualifications. ${ }^{231}$ We suspect, however, that something similar may be continuing today.

In order to investigate this proposition, we asked 250 elite firms to tell us the law school attended by each member of their most recent entering class of associates and to indicate which of these lawyers is black. The results of this survey, although far from conclusive, suggest that the blacks who are hired by elite firms tend to come from the superstar end of the distribution in terms of the key variable of law school status. The percentage of black associates identified by this survey who were graduates from elite schools is only 5\% higher than the percentage for nonblack associates. ${ }^{232}$ However, the black associates tend to come from schools at the top of the elite range. Thus, graduates from Harvard Law School constituted $24 \%$ of all of the blacks in our law firm survey. ${ }^{233}$ Even if we limit the universe of qualified African-American applicants to the graduates of the schools from which the firms in our survey actually hired during the year in question, this percentage is nearly four times greater than the percentage of black Harvard graduates in the available pool. . $^{24}$

The numbers are even more striking in New York and Washington, the two cities with the largest concentration of elite firms. In New York, Harvard graduates constitute $15.6 \%$ of the total number of black associates hired. ${ }^{235}$ However, when we add black graduates from Columbia

229. See supra note 171 , and accompanying text.

230. As a reminder, we assert that this is the result that would obtain in the absence of affirmative action.

231. See SEGAL, supra note 14, at 77-78, 218-19 (documenting the extraordinary qualifications of the first generation of blacks to enter into elite law firms).

232. Appendix, Table 3, (reporting that $57.3 \%$ of the entering black associates were from elite law schools as compared to $51.7 \%$ of non-black associates).

233. Id.

234. Id. (indicating that $24 \%$ of the total number of blacks hired graduated from Harvard and that Harvard's graduating class of black students constitutes $6.1 \%$ of all black students graduating from any law school from which any black student was hired by one of the firms responding to our survey). Table 4 lists all of the law schools from which the firms in our sample hired black associates and the number of these lawyers that were hired from each school.

235. Appendix, Table 3. 
and New York University, the percentage rises to 51.1..$^{236}$ Similarly, in Washington, D.C., black Harvard graduates account for $32 \%$ of the total blacks hired. ${ }^{237}$ When we include black graduates from Georgetown, ${ }^{238}$ these two schools account for $52 \%$ of the total. ${ }^{239}$

Admittedly, there are problems with this data, as well as alternative hypotheses that can also explain these results. Only one-third of the firms responded to our survey (although the response rates in New York and Washington, D.C. were $51 \%$ and $50 \%$ respectively). In addition, the number of blacks in the survey is small, and the results are only for one year. ${ }^{240}$ Moreover, because of affirmative action in law school admissions, it is possible that Harvard and other similar schools have a disproportionate share of the talented black students. Although this would still mean that firms tend to hire blacks from the superstar end of the distribution, it would weaken the corresponding implication that the black graduates from other elite schools that are less well represented are being unfairly overlooked in favor of white graduates from those same institutions. For affirmative action in law school admissions to account for these differentials, however, the gap between the quality of black students from, for example, Harvard and the University of Michigan or the University of Pennsylvania (two elite schools that contributed only two black associates apiece to our sample), must be substantially larger than that between white students from these same institutions. ${ }^{241}$ So far as we know, there is no evidence to support the existence of a gap of this magnitude.

Moreover, to the extent that these considerations overstate the importance of top echelon schools like Harvard in our sample, there are other forces that seem likely to pull in the opposite direction. For example, a comparison between the percentage of black associates in our sample and the latest information about blacks in corporate firms suggests that the firms that chose to respond to our survey have more

236. Id.

237. Id.

238. Id. Although Georgetown is not one of our elite schools, it is the best law school in Washington, D.C. Not surprisingly, most of the black and white associates from Georgetown in our sample were hired by Washington, D.C. firms.

239. Id.

240. Our difficulty in getting firms to respond to even this simple request for information underscores why there is so little hard data in this area. As for the small sample size for blacks, this is. of course, due in part to the very problem we are studying-the small number of blacks in corporate firms.

241. To the extent that attending a law school at the top of the elite range is no noisier a signal for blacks than it is for whites, in the absence of a systematic preference for average whites over average blacks, we should expect to see both groups hired at the same rate that they appear in their respective pools. 
blacks than average. ${ }^{242}$ In addition, given recent initiatives to increase minority hiring undertaken by bar associations around the country (including those in New York and Washington, D.C.), it seems likely that firms responding to our survey have engaged in more affirmative action in hiring this class of incoming associates than in previous years. ${ }^{243}$ Both of these factors seem likely to increase the chances that average blacks, that is, those without superstar credentials like attending an elite law school, would make it into our sample.

Indeed, when we look back to a period when by all accounts there was less affirmative action than there is today, we find evidence that going to an elite law school was even more important for blacks. Table 5 compares the law schools attended by all of the identifiable black partners listed in the Minority Partners Handbook with the credentials of all partners in five national law firms. ${ }^{244}$ The results suggest that the current generation of black partners are much more likely to have graduated from an elite law school then their white counterparts. Thus, $77 \%$ of all black partners attended one of the eleven elite law schools where corporate law firms have traditionally done most of their recruiting. ${ }^{245}$ In contrast, the combined percentage of elite graduates at five of the nation's most elite firms is $70 \%$, with firms such as Atlanta's Kirkpatrick and Cody drawing less than half of their partners from these schools. ${ }^{246}$ When we narrow our focus to graduates from Harvard and Yale, the two schools generally considered to be at the top of the status hierarchy, the results are even more dramatic. ${ }^{247}$ Fourty-seven percent of the black partners at elite firms attended Harvard or Yale, a percentage only surprassed by Boston's Ropes \& Gray. None of the other firms has more than $41 \%$ of its partners from these two institutions, and the average for the five firms is only $33 \% .{ }^{248}$ More importantly, if we remove graduates of Howard Law School from the percentage of black partners from non-elite schools, a reasonable supposition in light of the unique posi-

242. Blacks constitute $7.6 \%$ of the associates hired in our survey as compared to the national average of $2.4 \%$ of all associates who are black. Compare Appendix, Table 3 with Davis, supra note 15 , at 1 .

243. See id. (reporting that the jump in minority associates was due in part to firms agreeing to goals and timetables to increase minority participation).

244. The information on black partners was gathered from CoNFERENCE ON MINORITY Partners in Majority/Corporate Firms, American Bar Association, Minority Partners in Majority/Corporate Firms: Professional Profiles (1992-93 ed.).

245. Appendix, Table 5.

246. Id.

247. For example, the 1995 U.S. News and World Report ranking of American law schools places Yale and Harvard as numbers one and two, respectively. See The Top 25 Law Schools, U.S. NEWS \& WORLD REPORT, Mar. 20, 1995, at 84.

248. Appendix, Table 5. 
tion that Howard holds for black lawyers, ${ }^{249}$ the liklihood of a black partner attending a non-elite school is approximately a third less than that for the general population of partnes at the sampled firms. ${ }^{250}$

Once again, this comparison is not definitive. To highlight the most obvious complication, we do not know whether the population of black partners is representative of the other blacks who might have been hired at the same time bnt who did not win the tournament. Nevertheless, the fact that so many of the current generation of black partners attended elite schools at a time when law school affirmative action policies were less entrenched then they are today suggests that the similar effects we observed in our survey of associates reflect a tendency for the black associates who are hired by elite firms to come disproportionately from the superstar end of the distribution. Anecdotal descriptions of the recruiting process by some black partners provide further support for this assessment. ${ }^{251}$ If this is correct, however, it brings up a further paradox: if black associates are disproportionately clustered in the superstar range, why are there so few black partners? This brings us the question of retention.

\section{B. Retention, Promotion, and Survival}

Virtually all the blacks who start at a given elite law firm leave before becoming partner. ${ }^{252}$ In this Section, we examine how the institutional characteristics of elite firms-high salaries, pyramiding, and tracking-affect a black associate's partnership prospects. Unlike others who have addressed this issue, however, we concentrate on more than partnership rates. To understand why there are so few black partners, one must investigate what happens both before and after the partnership decision - and what opportunities are available for those who leave.

249. Until the mid-1970s, Howard was virtually the only law school with a significant number of black graduates. Even after other schools began admitting blacks, Howard's reputation for excellence and its connection to the civil rights movement combined to attract black students whose credentials would have allowed them to attend an elite law school. In recognition of these factors, Howard is the only historically black law school from which elite firms recruit with any frequency.

250. Appendix, Table 5.

251. For example, Davis reports a black partner at Chicago's Sidley \& Austin as contending that firms "set higher standards for minority hires than for whites" and contending that "[i]f you're not from Harvard, not from Yale, not from the University of Chicago, you're not adequate. You're not taken seriously." See Davis, supra note 15, at 22.

252. See supra note 170, and accompanying text. Our data on black Harvard Law School graduates supports this conclusion. For example, only $14 \%$ of our sample of black graduates from the classes of 1981 and 1982 were still affiliated with the law firms at which they started their carcers. Assuming both that these lawyers all became parners and that those who left did not become partners at another elite firm, the partnership rate for black Harvard Law School graduates is substantially below the average for any major metropolitan city-including New York. See Appendix, Table 1 and Figure 3. Although both of the assumptions underlying this comparison are controversial (i.e., some of the $14 \%$ still at their original firms are "of counsel"or non-equity partners just as some who left undoubtedly made partner at other elite firms) the comparison is nevertheless instructive. 


\section{Monitoring, Mentoring, and Marketing: Getting on the Training Track}

Elite firms make few formal distinctions among entering associates. The implication is that associates in a class are part of a unified group operating on a level playing field. In Part $\Pi$, we argued that the reality is otherwise. Although firms maintain few formal distinctions, the inevitable scarcity of training opportunities pushes associates along informal, but nevertheless identifiable, career paths almost from the moment they arrive. The few associates who get on the training track will receive interesting work, meaningful training, supervision, and supportive mentors. The others will end up as flatliners drowning in a sea of routine paperwork.

Empirical and anecdotal reports about the practices of elite law firms support this account. From the "golden age" forward, associates have been lured to join big firms by the promise of excellent training. ${ }^{253}$ For the reasons outlined above, these promises are difficult to keep. ${ }^{254}$ As a result, "associates voice strong concerns about the lack of on-thejob training, delegation, supervision, and feedback."25s

These complaints, although pervasive, are not uniform even among associates at a single firm. ${ }^{256}$ Instead, some associates report that they

253. For the role that promises about training continue to play in associate recruitment, see, e.g., Cynthia F. Epstein, Women In Law 181 (2d ed. 1993) (reporting that many young lawyers join large law firms because they expect to be trained); Allison Frankel, What Ever Happened to the Class of '83?, AM. LAw., Oct. 1993, at 53, 54 (reporting that associates join Paul Weiss for training, contacts, and the allure of the firm's name).

254. See Joel F. Henning \& Mindy A. Friedler, Training Senior Lawyers to be Better Trainers, LAw Prac. MGMT., Mar. 1993, at 60,61 "The practice of law has changed dramatically in the past 10 years, and one of the casualties has been associate training and development.").

255. Id. The following comments from the American Lawyer 1994 survey of mid-level associates are representative of these complaints;

Life and prospects for nineties associates [at Los Angeles' Lewis, D'Amato] are not rosy.

Before they fired all the human, tutorial partners, training here was above average. Since

[the] firings, partner files have been transferred to associates, who are forced to fly by the

seat of their pants. Now there is much more responsibility but less mentoring.

Midlevel Associates Survey: Seeking Quality of Life, AM. LAw., Oct. 1994, at 43 [hereinafter Associates Survey].

"Life at [New York's Cleary, Gottlieb] does not seem to include any training, feedback, or guidance that would foster one's development as a lawyer." Id. at 65 . "No one [at Washington, D.C.'s Shaw, Pittman] takes an interest in my legal development, and when 1 inquire about a higher level of work-that involving more responsibility or litigation experience-l am ignored." Id. at 88. "[T]raining [at Washington, D.C.'s McKenna and Cuneo] is so poor that [associates] are highly unmarketable." Id. at 89.

256. For example, compare the following comments from two mid-level associates at Washington, D.C.'s Howrey and Simon: "There is very little opportunity for associates to get into court or get any significant litigation responsibility .... Thus, even for mid-level associates, much of the work is brief-and motion-writing-perhaps with some depositions-and little court or client contact." Id. at 87. "The firm is a true meritocracy. Associates who do good work are rewarded with greater responsibility regardless of where they went to school, how long they have been at the firm, etc." Id. 
receive valuable training opportunities while others do not. ${ }^{257}$ In addition, once an associate acquires a reputation as being well-trained, she will continue to receive training in the form of demanding work. ${ }^{258} \mathrm{Al}$ though managing partners understandably continue to deny that firms track incoming associates, ${ }^{259}$ more detached observers, ${ }^{260}$ as well as partners in more candid moments, ${ }^{261}$ report the contrary.

An associate's perception about which track she is on will have a substantial impact on how long she decides to stay with the firm. ${ }^{262}$ Associates know that firms look for two things when they select partners: legal ability and marketing potential. ${ }^{263}$ An associate who has not been trained cannot credibly signal either of these capacities. Training is the Royal Jelly that enables associates to develop the job-related skills

257. The American Lawyer reports on Cleveland's Baker \& Hostetler and Philadelphia's Morgan, Lewis and Bockius underscore these differences. "The key to receiving topflight training at Baker \& Hostetler, according to the 16 associates (out of 54 eligible) appears to be finding good mentors. Written comments indicated that the quality of associate training depended entirely upon the partners and senior associates overseeing them." Id. at 37.

The written comments provided by 20 associates in various offices of [Morgan, Lewis and Bockius] suggest that associates' experiences vary widely. One Philadelphia third-year complained that "mentoring is almost nonexistent," but another contended that "the firm makes a strong effort to overcome the types of problems that typically arise for associates Id. at 73 .

in a large firm (e.g., limited courtroom exposure) by providing extensive training."

258. See id. at 44 ("The partners at Jones, Day are willing to give associates as much responsibility as they demonstrate they can handle. This is a positive aspect-but also turns into a negative one. Once you demonstrate your ability, you are a valuable commodity, and the pressure to work with various partners becomes intense.").

259. See, e.g., id. at 88 (quoting a management committee member as stating, "l think this is evidence of generalized anxiety. It's always wrong, but it's nonetheless persistent that there's some group of pre-ordained superstars.").

260. See Henning \& Friedler, supra note 254 , at 61 (noting that "[o]nce partners find associates they like who can do the work, they're more than happy to continue delegating work only to those associates"). The authors point out that this can sometimes hurt even those who get this kind of responsibility by "pigeonhol[ing] them in narrow responsibilities" which may result in their becoming lawyers who charge "senior-level fees for junior-level work." Id.

261. See Chambliss, supra note 7, at 94 (quoting a senior partner who acknowlcdges the existence of an informal tracking system for associates).

262. We use the word perception advisedly. Firms give associates relatively little concrete information about their progress and what is said is often unreliable. See, e.g., Associates Survey, supra note 255, at 64 (quoting a mid-level associate at Cleary, Gotlieb as reporting "the formal evaluations are generic in tone and completely unhelpful"). This is hardly surprising. Given that firms rely on both the "carrot" of winning the partnership tournament as well as the "stick" of losing this scarce high-paying job to motivate their associates, they have an incentive to keep associates in the dark as long as possible about their partnership prospects. As a result, a flatlining associate may not know that she is in trouble until it is too late. This is particularly true because, as Figure 1 makes clear, a flatlining associate may be working quite hard in her early years--often harder (and making more money for the firm) than an associate who is receiving Royal Jelly. 1t is only when she realizes that others are getting more responsibility while her own work both diminishes and continues unchanged that she will begin to suspect that her career has stalled.

263. See CAPLAN, supra note 67 , at $263-74$ (describing the criteria for making partner at Skadden Arps). 
partners expect to see in those who will be elevated to their rank. ${ }^{264}$ Similarly, although an associate may have business contacts independent of the firm, the most likely way for an associate to demonstrate her rainmaking skills is through contact with the firm's existing clients. Such contact is one of the commodities that training can help an associate accrue. ${ }^{265}$

The effect on lateral movement is equally plain. The implicit promise that big firm associates are well trained lies at the heart of their marketability. ${ }^{266}$ Associates therefore work to avoid sending any signal that might tend to refute this presumption. Being fired is, of course, the ultimate negative signal, but failing to receive the same training opportunities as one's peers may also adversely affect one's lateral mobility. The fact that others are getting better work experience will not only lead an associate to doubt her own partnership chances, but may also lead her to believe that she will have less success in signaling to other potential employers that she is well-trained. Whether or not these fears are justified, ${ }^{267}$ they are likely to increase the pressure to look for another job.

Associates who do not find themselves on the training track have three options: (i) they can leave immediately; (ii) they can attempt to move themselves onto the training track; or (iii) they can stay at the firm but invest their time and energy in developing non-firm-specific skills that will help them get another job. Which of these strategies a given associate will pursue depends upon both the likelihood that she can change her reputation within the firm and her prospects in the external employment market. We believe that African-American associates face important barriers on both of these fronts. We therefore turn our attention to the particular experiences of black lawyers.

264. In addition, because skill and rainmaking potential are difficult to observe or evaluate without investing substantial time, partners are likely to rely on the opinions of those partners who have had first-hand experience with the candidate. An associate who has not entered into one or more of the complex mentoring/training relationships described above is less likely to have such knowledgeable advocates among the partners.

265. In addition, partners are also likely to favor trained associates even in circumstances where it might not be in the firm's interest to do so. When the existing partners of a firm decide on which of their eighth- to tenth-year associates to elevate to their own ranks, each partner has an interest in promoting his or her proteges. The proteges owe their mentors allegiance because the mentors chose to invest in them. This presumably means that the proteges will repay their mentors by providing them with clients or voting not to fire them when the proteges are at their most productive and the mentors are older and less productive.

266. See, e.g., Kordana, supra note 106, at 1932 (arguing that government and business enterprises want to hire associates "because a large law firm is such a good training ground for young attomeys").

267. As we argue above, potential employers may be less able to distinguish between trained and untrained lateral candidates than those candidates might suspect. See supra note 148 and accompanying text. 


\section{Concrete Ceilings and Slippery Floors: The Black Experience in Corporate Firms}

Black associates face three significant barriers to getting on the training track. First, they are less likely than whites to find mentors who will give them challenging work and provide them with advice and counseling about how to succeed at the firm. Second, they face higher costs from making mistakes than their white peers. Third, their future employment prospects with other elite firms diminish more rapidly than those of similarly situated associates.

\section{a. Mentoring and Irrationality ${ }^{268}$}

In order to get on the training track, an associate has to have mentors among the firm's partners or senior associates who can provide the Royal Jelly of good training. Blacks consistently report that they have difficulty in forming these supportive relationships. For example, in our survey of black Harvard Law School graduates, less than $40 \%$ of those surveyed, and only $24 \%$ of the pre- 1986 graduates, stated that a partner had taken interest in their work or their career. ${ }^{269}$ Sixty-eight percent of those who did not find a mentor, including $79 \%$ of the post1986 graduates, stated that this was a significant factor in their decision to leave the firm. ${ }^{270}$ Although we do not have comparable data on white associates, our hypothesis that blacks have an especially difficult time finding mentors in consistant with the views of others who have examined the issue. ${ }^{271}$ There is reason to believe that the situation is even bleaker for black women, who confront gender as well as racial barriers to forming meaningful mentoring relationships. ${ }^{272}$

268. We borrow the phrase from David Thomas. See David A. Thomas, Mentoring and Irrationality: The Role of Racial Taboos, 28 HuM. RESOURCE MGMT. 279 (1989).

269. Appendix, Table 2, Part B.

270. Id.

271. Bar associations reports on the problem of minority retention consistently emphasise that black lawyers have difficulty finding mentors. See, e.g., S.F. REPORT, supra note 33, at 14; N.Y. REPORT, supra note 12, at 84-85; see also Caroline V. Clarke, The Diversity Dilemma, AM. LAW., Oct. 1992, at 31 (reporting that "African-Americans perceive more race-related barriers to obtaining adequate mentors, challenging work, direct client contact, and partnership" than either whites or members of other minority groups); Alexander Stille, Litlle Room at the Top for Blacks, Hispanics, NAT'L L.J., Dec. 23, 1985, at 1, 9 (reporting that blacks have a harder time finding mentors than their white counterparts).

272. A number of important studies have documented the difficulties women face in entering meaningful mentoring relationships. See, e.g., EPSTEIN, supra note 253, at 287-88; Grace M. Giesel, The Business Client Is a Woman: The Effect of Women as In-House Counsel on Women in Law Firms and the Legal Profession, 72 NEB. L. REv. 760, 777-79 (1993). In light of both the added complexity that racial difference adds to interactions between women and men, as well as the greater difficulty that women face in creating supportive mentoring relationships across racial lines, these problems are likely to be even greater for black women. For discussion of the manner in which race and sex intersect to form unique "tahoos" that inhibit mentoring relationships, see Thomas, supra note 268. See also HaRrington, supra note 168, at 101-02 (reporting that black women have a particularly 
A number of factors contribute to this problem. Chief among them is the bias that potential mentors have for proteges who remind them of themselves. ${ }^{273}$ Studies of cross-racial and cross-gender mentoring relationships in the workplace repeatedly demonstrate that white men feel more comfortable in working relationships with other white men. ${ }^{274}$ Anecdotal evidence suggests that white partners in law firms are no different. ${ }^{275}$ This natural affinity makes it difficult for blacks to form supportive mentoring relationships.

These problems are magnified in a low-monitoring environment. Because partners have little information about a new associate's actual skils, the decision about who is a superstar worthy of training will be made as an initial matter in the same way as it is done at the recruiting stage-based on a few easily observable signals such as law school status, academic honors, and grades. Indeed, since partners not on the recruiting committee will probably not have met the great majority of incoming associates (nor seen their credentials) decisions about which of these lawyers are superstars will be even more loosely correlated with these signals than typical hiring decisions. Under these circumstances,

difficult time "desexualizing" their bodies and therefore face additional barriers to forming supportive relationships with white male superiors).

273. This point was first made by Rosebeth Kanter in her study of women in corporations. See Kanter, supra note 7, at 47-49; see also Crnthia F. EPSTEIN, Woman's Place: Options and Limits in Professional CAREers 168-70 (1970) (finding that women had difficulty finding mentors; older male colleagues tended not to take on young female protegees because they did not see women associates as younger versions of themselves in the way that they saw some young male associates). But see Cynthia F. Epstein et al., Glass Ceilings and Open Doors: Women's Advancement in the Legal Profession, 64 FordhaM L. Rev. 291, 353-56 (1995) (reporting that some women partners expressed ambivalence about mentoring women associates, both because they themselves had succeeded without mentoring and because they feared that strong support of a woman associate would be seen as self-interested). Needless to say, this latter problem further disadvantages women protegees by removing one possible avenue for making up for the lack of male mentors.

274. Professor David Thomas has been a leader in this research. See, e.g., David A. Thomas, Racial Dynamics in Cross-Race Developmental Relationships, 38 ADMIN. ScI. Q. 169 (1993) [hereinafter Thomas, Racial Dynamics]; David A. Thomas, The Impact of Race on Managers' Experiences of Developmental Relationships (Mentoring and Sponsorship): An Intra-Organizational Study, 11 J. Organizational Behav. 479 (1990); David A. Thomas \& Clayton P. Alderfer, The Influence of Race on Career Dynamics: Theory and Research on Minority Career Experiences, in HaNdBooK of Career Theory 133, $141-43$ (Michael B. Arthur et al. eds., 1989). Thomas emphasizes that despite these difficulties, blacks and whites can, under certain conditions, enter meaningful mentoring relationships. See, e.g., Thomas, Racial Dynamics, supra, at 176-77, 192.

275. For example, consider the following report by a black lawyer who went to see a partner about a possible assignment only to find the partner already talking to two white associates:

When this partner looks at these guys, he looks for himself back in [the old days], or for his son one day. I thought to myself, "The reason I'm not in this room is because my world in his mind has nothing to do with his world." And no matter what schools you went to or how much Ieverage you think you have, or sometimes, even what the client says, people are going to work with whomever they feel most comfortable, with who [sic] they most identify with.

Clarke, supra note 271 , at 32 . 
background prejudices and preconceptions can lead white partners to believe that black associates are more likely to be average or perhaps even unacceptable. ${ }^{276}$

As indicated above, blacks may also suffer from a general perception that they are "less interested" in corporate work than other lawyers. ${ }^{277}$ This sentiment may be reinforced by the fact that black associates appear to be more likely than their white peers to do more than the average amount of pro bono work, to hold skeptical views about the social utility of some of the goals of their corporate clients, and to leave corporate practice for jobs in the public sector. ${ }^{278}$ As with recruiting, black women face an additional hurdle, since partners frequently believe that family responsibilities will inevitably reduce the number of hours these associates are willing to commit to the firm. ${ }^{279}$ The fact that these generalizations say almost nothing about any individual black associate's level of interest or commitment to the firm is unlikely to dissuade partners from relying on such gross statistical correlations when deciding whom to mentor.

Finally, black associates will have difficulty getting onto the training track precisely because the generation of black associates before them did not. Partners have less incentive to invest scarce training resources in associates who they think are unlikely to be at the firm long enough for them to recoup their investment. Not only are black associates less likely to make partner, but their average tenure may also be shorter than that of their white peers. ${ }^{280}$ As a result, black associates are

276. For example, in a Diversity Training videotape distributed by the San Francisco Bar, a black woman reports that when a rumor began circulating around her firm that one of the new associates had failed the bar, several partners immediately assumed that it was her even though she had in fact passed not one but two exams. See A FIRM Commitment (Bar Association of San Francisco). The student who failed was white; see also Donna Gill, Lawyers of Color: Encouraging Diversity, CHI. LAw., July 1992, at 1 (“'Minorities do not come in with [a] presumption of competence,' [Lord, Bissel \& Brook partner W. Muzette] Hill said. 'They come in having to prove themselves. That in and of itself sets the tone. Everything flows from that. Then human nature being what it is, people tend to be drawn to, want to nurture, or are more tolerant of people just like them."'); Campbell \& Tomkins, supra note 215.

277. See supra note 39 and accompanying text.

278. For example, in our study of black Harvard Law School graduates, $86 \%$ reported doing a significant amount of pro bono work, while $33 \%$ left their firm for a govemment job. Appendix, Table 2, Part A. These numbers appear to differ from what one would find in the general population. See Marc Galanter \& Thomas Palay, Public Service Implications of Evolving Law Firm Size and Structure, in THE LAw FIRM AND THE PUBlic Good 19, 42 (Robert A. Katzmann cd., 1995) [hereinafter PuBLIC Goop] (reporting that less than $40 \%$ of the associates at large firms did more than 20 hours of pro bono work in 1994, up from 30\% in 1993); see also Wilkins, Social Engineers, supra note 8 (citing evidence that blacks tend to be on average more skeptical about both the faimess and the social utility of the current distribution of wealth and power than whites).

279. See supra note 218 and accompanying text.

280. In our survey of black Harvard Law School graduates we found that the average tenure for black Harvard Law School graduates was 3.04 years and 2.32 years for the pre- and post-1986 samples respectively. See Appendix, Table 2, Part C. These rates appear to be lower than those for 
doubly penalized for the firm's failure to retain and promote black lawyers.

\section{b. Visibility and Tokenism}

Sociologists contend that when a group's representation in the workforce is small, individual members face increased pressures to perform and conform. ${ }^{281}$ Although these pressures can work to the "token's" advantage, the dominant tendency is for them to magnify the cost of making mistakes. Reports by black associates lend credence to this hypothesis.

Black associates frequently state that they are judged more harshly when they make mistakes than their white contemporaries. For example, over $40 \%$ of our survey respondents reported that they were criticized more than white associates for making similar mistakes. ${ }^{282}$ Even if these respondents are mistaken about this, the fact that they believe it to be true may induce some black associates to embark on the counterproductive career strategies we describe below. There is reason to suspect, however, that these reports are not simply a product of the black associates' collective imagination. A low-monitoring environment amplifies negative signals. For black associates the problem is exacerbated by expectations. If, for the reasons outlined above, partners expect black associates to be average or unacceptable, then any mistake will be seen as confirming this initial assessment. ${ }^{283}$ Mistakes by whites, on the other hand, are more likely to be dismissed as "aberrational" or "growing

the associate population as a whole. For example, a survey of the Harvard Law School class of 1981 found that $74.52 \%$ of those starting at a large firm had not changed jobs as of 1985 . See David N. Schultz, Harvard Law School Graduates: Where They Are and How They Got There 26 (1985) (unpublished manuscript on file with the author) (analyzing Harvard Law School's Career Path Study).

281. See KANTER, supra note 7, at 210, 212 ("The proportional rarity of tokens is associated with three perceptual tendencies: visibility, contrast, and assimilation.... Visibility tends to create performance pressures on the token. Contrast leads to heightening of dominant culture boundaries, including isolation of the token. And assimilation results in the token's role encapsulation.") (emphasis omitted).

282. See Appendix, Table 2, Part B.

283. This is a point about calculating conditional probabilities based upon prior views about what the distribution of signals from a particular group is likely to be. Ideally, the evaluation process works as follows: An associate performs a task, that performance provides the partner with a signal, and based upon that signal the partner calculates the probability that training this associate will be a good investment. The more closely the partner can evaluate the associate's work, the less need there is to base the calculation on information extrinsic to the actual performance. In a world where information is expensive to collect, however, partners must make evaluations in light of their background hunches. The signal the partner gets is combined with the partner's prior hunches about the associate to produce an implicit calculation about the associate's potential. The vaguer the signal, the stronger the effect of the hunches in influencing the final calculation. 
pains," since these associates are presumed competent in the absence of conclusive evidence to the contrary. ${ }^{284}$

Finally, small numbers also increase the probability that group members will be tied together in the minds of members of the dominant group. ${ }^{285}$ To the extent that white partners think (consciously or unconsciously) that "we had a [black] once and he didn't work out,"286 the chances of any other black lawyer having a successful career at the firm are correspondingly reduced.

Collectively, these aspects of tokenism encourage black associates to think about outside job possibilities. ${ }^{287}$ What they see when they examine the lateral job market, however, is likely to make them even more concerned about their future.

\section{c. Bringing the Outside In}

The pyramid structure of the elite law firm ensures that the vast majority of associates leave without becoming partners. When they leave, however, depends in part on their perceptions about the lateral market. Lawyers wishing to move laterally face conflicting incentives. On one hand, the longer they stay, the more they can claim to have accumulated valuable skills. On the other, the closer they are to partnership, the greater the danger that potential employers may presume that they are leaving because they are not "good enough" to make partner. ${ }^{288}$

For black associates, the decision is less complex but more draconian. It is less complex because blacks may not receive the beneficial

284. See also Herman, supra note 171 , at 13 (quoting an associate at Jenner \& Block: "When [whites] make a mistake, the reviewing attomey might have said, "Well, maybe my instructions weren't clear enough.' . . . But with a minority, ... ' [s]uddenly that person is incompetent."'). To be sure, small numbers can also produce the opposite asymmetry between blacks and whites: because of diminished expectations, a black associate who does an exceptionally good job may receive more credit than would a similarly situated white associate. Since we assume that blacks are at least as capable (on average) as their white peers, one might think that this positive asymmetry would more than offset the negative one described in the text. However, given that most of the work done by associates (particularly black associates) in their first few years could be done by anyone with average ability, competently performing these tasks will only signal that a black associate is located in the average range. Being considered average, however, is not generally enough to secure success in the promotion-to-partnership tournament.

285. This is what Kanter refers to as contrast. See KANTER, supra note 7, at 210-12.

286. Bates \& Whitehead, supra note 12 , at 84 (paraphrasing an attitude they believe is common in large law firms).

287.

"A bright young associate can analyze something" says [Hogan \& Hartson partner] Vincent Cohen. "He or she will say, 'Look, I see what it takes to be a suceessful partner. I am not going to be able to produce the kind of business I need to make it, so better I make my swing now while I am still employable."'

Keeva, supra, note 2167 at 53.

288. See supra note 144 . 
presumption that comes from length of service. Length of service is only positively correlated with skill if an associate has been trained. Since making quality judgments is difficult in the lateral market, firms are likely to rely on statistical approximations. To the extent that firms are aware of the barriers faced by black associates regarding getting on the training track, employers looking for lateral hires may be less likely to believe that a black lawyer has been well trained (even if he has been). Given the large number of lateral applicants, a firm that hires fewer average black laterals will not suffer a competitive disadvantage. As a result, a black lawyer will expect more difficulty in moving laterally to another large law firm than will his white counterparts.

Our survey of black Harvard graduates provides some support for this conclusion. Only $15 \%$ of the black lawyers who had left their first elite firm went to another one. ${ }^{289}$ Instead, the majority went into either government $(33 \%)$, corporate legal departments $(20 \%)$, or small nonelite firms (17\%). ${ }^{290}$ This distribution appears to be significantly different from that for whites. ${ }^{291}$

Given this distribution, we hypothesize that the optimal time for black associates to leave firms is earlier than that for white associates because whites do not face the general market presumption that they have not been trained. Within the first few years, the common perception is that no one has received much training, so blacks suffer no particular disadvantage. Indeed, the only significant new signal potential lateral employers have to look at is the fact that the associate was hired by his first firm and has been at least minimally competent. (If a black associate were not minimally competent, he would have been fired.) This additional credential, may be even more valuable for blacks, since the second firm can rely on the first firm to screen out those blacks who are in the unacceptable range.

Blacks, therefore, have an incentive to make decisions about moving laterally even more quickly than whites. This incentive in turn affects the choices these associates make while at the firm. On average, the strategies black lawyers are likely to pursue will decrease their chances of succeeding at the firm even further.

289. Appendix, Table 2, Part A

290. Id.

291. Professors Revesz and Kornhauser's study of lawyers from the University of Michigan and New York University supports this intuition. They report that while black lawyers are equally likely, if not more so, to take elite firm jobs upon graduation, they end up disproportionately in the not-forprofit sector. Komhauser \& Revesz, supra note 23, at 931-34; $c f$. S. Elizabeth Foster, Comment, The Glass Ceiling in the Legal Profession: Why Do Law Firms Have So Few Female Partners, 42 UCLA L REv. 1631, 1682 (1995) (reporting that the discriminatory environment causes women to leave "private practice" in disproportionate numbers). 


\section{d. Rational Strategies in the Face of Reasonable Fear}

Black associates find themselves in a double bind. On one hand, they understand that they are less likely to get on the firm's training track. On the other, they face diminishing opportunities in the lateral job market the longer they stay at the firm. This combination produces a level of fear and anxiety about the future that is, even from the firm's perspective, sub-optimally high. ${ }^{292}$ As we argued in Part II, elite firms rely on the fear of job loss or diminished partnership prospects as a means of inducing associates to work hard at low monitoring costs. Like all motivational tools, however, fear has its own rate of diminishing marginal utility. When fear levels are sub-optimally low (in a low monitoring world), associates and partners have an incentive to shirk. When levels are sub-optimally high, lawyers have an incentive to adopt career strategies that reduce their benefit to the firm.

For the forgoing reasons, black associates are especially vulnerable to these pressures: ${ }^{293}$ As a result, they have strong incentives to choose career strategies that either minimize the danger of sending a negative signal or, conversely, maximize their opportunity for being regarded as superstars. Both strategies, however, can end up diminishing a black associate's long term chances for success at the firm.

\section{i. Low-Risk Strategies}

An associate wishing to reduce the chance of making mistakes can either steer clear of demanding assignments (because of either the difficulty of the work or the level or intensity of the scrutiny likely to be given by the partner) or take fewer risks in completing the work. There is some evidence to suggest that black associates disproportionately pursue both of these strategies.

Considering the choice of specialty, many observers believe that corporate practice in general (as opposed to litigation), and related specialties such as tax, securities, and banking in particular, require higher levels of substantive legal knowledge and technical skill than other fields of practice. ${ }^{294}$ Moreover, these areas (particularly specialties such as tax) tend to have lower associate-to-partner ratios. ${ }^{295}$ Consequently, associates in these areas are more closely supervised, thereby increasing the odds that mistakes will be detected.

292. It goes without saying that the constant fear and anxiety felt by many black associates is harmful to their self-interest.

293. It bears repeating that many whites are also vulnerable to these pressures. The added burdens of race-based disadvantage simply push blacks towards the extremes.

294. See Heinz \& LAUMANN, supra note 66, at 55-73. This perception undoubtedly influences, and is influenced by, the related view that law school courses in these subjects are among the most demanding. See supra notes 209-210 and accompanying text.

295. See Kordana, supra note 106, at 1927-28. 
Blacks appear to be underrepresented in these high-level corporate areas. In our survey of Harvard black alumni, only $32 \%(24 \%$ of the pre-1986 graduates) worked in corporate practice. ${ }^{296}$ Similarly, our review of the classes of 1981-1982 and 1987-1988 revealed a similar pattern: those in corporate practice accounted for $25 \%$ and $27 \%$ of the total number who were in elite firms. ${ }^{297}$ Of those who were in corporate practice, few worked in specialty departments such as tax. ${ }^{298}$ The distribution of black partners confirms this trend. Only $14 \%$ of black partners work in general corporate practice, and less than $11 \%$ specialize in technical fields such as banking (6\%), bankruptcy $(2 \%)$, and tax $(1 \%)$. ${ }^{299}$

Undoubtedly, there are many reasons why blacks do not go into these areas, ranging from a genuine lack of interest to the very real possibility that many black associates believe that specializing in other areas (particularly litigation) will improve their chances in the lateral job market. ${ }^{300}$ Nevertheless, just as the draconian consequences of sending a negative signal during the recrniting process can lead black students to avoid advanced corporate courses in law school, the probelms associated with being a token in a particualrly difficult area of practice is likely to produce a similar pattern of avoidance when blacks join firms. ${ }^{301}$

296. Appendix, Table 2, Part A.

297. Appendix, Table 1.

298. For example, only one lawyer in our data on the class of 1987-88 specialized in tax. See Appendix, Table 1.

299. Appendix, Table 6 (As a very rough comparison, consider three randomly selected elite New York firms. At Jones, Day, Reavis \& Pogue, $22 \%$ of the firm's lawyers are engaged in bankruptcy practice and $14 \%$ work in tax. At Kay, Scholer, Fierman, Hays \& Handler, $12 \%$ are bankruptcy lawyers and $5 \%$ are in tax. At Kelley, Drye \& Warren, the percentages are $4 \%$ bankruptcy and 5\% tax.); INSIDER's GuIDE, supra note 147, at 368-74 (The numbers for the banking departments were not reported.) Elizabeth Chambliss found that having a corporate, securities, or banking department was positively correlated with the number of black partners at firm, Chambliss, supra note 7, at 136. She does not claim, however, that black partners are likely to work in these practice areas. Instead, firms that have these specialty departments are more likely to have a broad range of other specialties as well, including those that attract black clients. As Chambliss demonstrates, the racial composition of a firm's client base is positively correlated with law firm integration, particularly for black lawyers. Id. at 141 . We return to this issue below. See infra notes 397-400 and accompanying text.

300. We retum to this latter possibility below. As for the former, to the extent that many blacks who go to elite firms have visions of using their Iegal skills to further the interests of the black community, high-level corporate practice may seem further removed from these concerns than other specialties. See Wilkins, Social Engineers, supra note 8 (discussing the relative importance of civil rights litigation and corporate practice to the black community). The fact that many people now view the struggle for racial justice in economic terms, however, may be changing these perceptions. This may account for some of the increased interest in corporate practice observed in later classes. On the other hand, this rise may also be due to the fact that recent graduates are less likely to define their career choices by their political commitments than their predecessors. In any event, for the reasons outlined above, one should always be suspicious of "lack of interest" explanations. See supra note 43 and accompanying text.

301. Several black partners working in the corporate area have told Professor Wilkins that these concerns make it more difficult for them to recruit black associates into their departments. The two 
Anecdotal evidence also suggests that black associates may, on average, be overly cautious when performing their work. Thus, those who study law firm interactions report that many black associates tend to speak less in meetings (particularly with clients), ask more clarifying questions when receiving work, are more likely to check (and recheck) assignments before handing them in, are more reluctant to disagree with partners or express criticism of their peers, and construe their assignments more narrowly than their white peers. ${ }^{302}$

From a black associate's perspective, both of these risk-averse strategies are rational responses to his environment. Given the inherent subjectivity of "good judgment," a risky action can be interpreted as either a sign of innovativeness and independence or a mark of stupidity and an inability to follow instructions. ${ }^{303}$ Since black associates have reason to fear that they are more likely to be branded with the negative description and that this characterization will be more difficult to shake, it is not surprising that they tend to be overly cautious in their choices.

Nevertheless, both of these risk-averse strategies reduce the gains (in terms of retention and promotion) that black associates can expect to receive from their work. Successfully completing "difficult" work assignments is the best way for an associate to signal her quality and therefore to demonstrate that she is worthy of training. Since partners are looking for associates who can work effectively with relatively little supervision, traits such as initiative, creativity, speed, and confidence are

phenomena (i.e. courses and job choices) are, of course, connected, since associates who have not taken courses in these areas are less likely to feel comfortable joining high-level practice groups.

302. See Jacob H. Herring, Derailed Over Diversity, Recorder, Nov. 6, 1992, at 7 (describing how non-participation in meetings is often interpreted differently based on the race of the silent individual); cf. Lani Guinier et. al., Becoming Gentlemen: Women's Experiences at One Ivy League Law School, 143 U. PA. L. Rev. 1, $32-33$ \& n.86 (1994) (reporting lower law school classroom participation by women).

303. Consider the following example of a high risk strategy pursued by a young associate: As a young associate with [a] large local law firm, Kenneth McClain saw his dream of becoming a big-time litigator within reach when he was assigned to work on the original Kansas City School District desegregation lawsuit. But instead of taking apart hostile witnesses in the courtroom, he spent week after week taking depositions in conference rooms.

Four months into the trial, McClain was to get his shot at cross-examining a witness in court. He carefully set his line of questioning, only to be told the cross-exam they had in mind was probably too hard and that he could question another, easier witness. McClain was disappointed, but quickly drew up a new set of questions.

"As I was about to stand up to do my cross-examination," McClain said, reliving as much as retelling the story, "a partner passed me a note that said, 'Ask one question,' and it had the question written out right there. And rather than being a good associate. I crumpled it up and put it in my pocket."

The cross-examination went so well that the firm's partners couldn't reprimand him.

Brian Kaberline, A Mind of His Own: McClain's Passion, Social Responsibility, Kan. CiTY Bus. J., Jan. 28, 1994, § 1, at 3. One can easily see how McClain's actions might have been interpreted had his "success" been less clear or his evaluator less sympathetic. 
highly valued..$^{304}$ The more risk-averse one is, however, the more difficult it is to signal that one has these qualities.

\section{ii. High-Risk Strategies: The Litigation Trap}

At the opposite extreme, a black associate may seek out demanding assignments in order to overcome the presumption that she is "only" average-or worse. For example, a black lawyer might volunteer to work with a particularly demanding partner or take on a large number of assignments. To the extent that a black associate successfully completes these projects, she has a better chance of signaling that she is a superstar and therefore worthy of training. The risks, however, are also high. If the project is particularly difficult or the partner especially demanding, the black associate who is in fact "average" has a greater chance of failing-and failing big. ${ }^{305}$ Similarly, the high effort strategy of taking on a large number of assignments can also fail if the projects suddenly become due at once.

Our research suggests that a large number of black associates are engaged, albeit unwittingly, in a particular variant of this strategy. Black associates are disproportionately concentrated in litigation departments. For example, $45 \%$ of the respondents to our survey, including $52 \%$ of the pre-1986 graduates, specialize in litigation. ${ }^{306}$ Our examination of the classes of 1981-1982 and 1987-1988 produced comparable numbers (50\% and $39 \%$, respectively). ${ }^{307}$ These data are consistent with the results of other studies. ${ }^{308}$ As Figures 4A-D indicate, these percentages are higher than the percentage of lawyers specializing in this area in all but the most litigation oriented firms. ${ }^{309}$

304. As a former partner in an elite firm who is now the general counsel to a major university told Professor Wilkins, what was most important to her in assigning work was that the associate displayed a "take charge" attitude that gave her the confidence to believe the assignment would be completed successfully.

305. For a particularly poignant (and perhaps egregious) example in a similar context of a high risk strategy gone awry, consider the strange career of Joseph Jett. A black graduate of Harvard Business School, Jett was initially unsuccessful as a securities trader (he was fired from two jobs for poor performance). At his third Wall Street firm, however, he developed a strategy for dramatically increasing the profits of the government trading desk. After making him a "superstar," however, this strategy eventually caused losses of $\$ 350$ million. The firm now claims that his strategy was fraudulent-a claim he vehemently denies. Either way, the strategy was clearly highly risky, and Jett is now paying the price. See Sylvia Nasar \& Douglas Frantz, Fallen Bond Trader Sees Himself as an Outsider and a Scapegoat, N.Y. TiMEs, June 5, 1994, at 1.

306. Appendix, Table 2, Part A.

307. Appendix, Table 1 .

308. See, e.g., McLachlan \& Jensen, supra note 15 (suggesting that women and minorities are more highly concentrated in litigation).

309. Appendix, Figures 4 A-D (Of the four firms shown, only Paul, Weiss has more than $40 \%$ of its lawyers in litigation. The other four firms average 32.33\%); see also Chambliss, supra note 7, at 117 (reporting that in her sample of large firms, the "average firm ... devotes about 30 percent of its practice to litigation services"). 
Just as with the shortage of blacks in high-level corporate areas of practice, many factors contribute to this over-concentration. ${ }^{310}$ One factor that is frequently overlooked, however, is that going into litigation is a plausible strategy for maximizing a black lawyer's career prospects. As an initial matter, litigation has been the most successful avenue to partnership for black lawyers. Fifty-six percent of the black partners at elite firms specialize in this area. ${ }^{311}$ Moreover, the fact that law schools tend to concentrate on teaching litigation related skills may make black lawyers feel better prepared to become litigators. ${ }^{312}$ To the extent that a black student seeks to acquire additional signals to overcome the presumption against average blacks, the ones most readily available (such as moot court, clerkships, and clinical placements) also tend to be connected to litigation. Finally, black associates might plausibly believe that litigation practice provides good opportunities for them to demonstrate their talents. Even the largest firms generally have a range of cases in their litigation departments, including some number of smaller cases that are being handled pro bono or at reduced rates as favors for important clients. Doing something visible in one of these cases might seem like a good way to get noticed. ${ }^{313}$

In addition to these benefits to an associate's career in the firm, litigation may also appear to be the best way for black lawyers to develop marketable skills. Although many kinds of corporate work are handled exclusively by elite firms, litigators are needed in many different settings, including government, small firms, solo practice, and inhouse legal departments. As we reported earlier, blacks are more likely to go into these areas when they leave corporate firms. Our survey indicates that for a substantial number of black associates, the possibility of

310. Once again, it is tempting to attribute this unusual concentration to voluntary choice. Litigation, after all, is the field of law most accessible to first-generation lawyers. See ABEL, supra note 38, at 108 (reporting that Catholics and Jews, many of whom were recent immigrants, were disproportionately eoncentrated in litigation). Similarly, litigation is also the field traditionally associated with efforts to achieve social justice through law. See Wilkins, Social Engineers, supra note 8. For the reasons set out above, however, the ability of firms to structure the demand for labor limits the "voluntariness" of these resulting choices. See AUERBACH, supra note 66, at 95-96, 99-100 (discussing how prejudice against recent immigrants limited their career options).

311. Appendix, Table 6.

312. As many commentators have noted, the typical law school curriculum is heavily skewed towards litigation. See, e.g., MARY ANn Glendon, A Nation Under LAWYers 224-25 (1993).

313. See Louise A. Lamothe, Where Have the Mentors Gone?, in The WoMAN Advocate 252 (Jean M. Snyder \& Andra B. Greene eds., 1995) (urging women who seek mentors and valuable experience to work on a pro bono case). The fact that formal training programs tend to be concentrated in the litigation area is likely to reinforce this effect. See Eric Herman, Big Firms Join Forces to Boost Lawyer Training, CHi. LAw., June 1994, at 1 (reporting that formal training programs tend to concentrate on litigation). We return to the incentives created by formal training programs below. See infra notes 362-364 and accompanying text. 
acquiring marketable skills is an important reason for choosing litigation in the first instance. ${ }^{314}$

Unfortunately, what look like advantages can turn out to have negative repercussions for a black associate's prospects at the firm. The lower levels of scrutiny in litigation increase the risk that an associate will fall through the cracks. On the typical case, there is a substantial amount of routine low visibility work. Because the teams are big, it is more difficult for partners to get any real sense of the quality of junior associates. ${ }^{315}$ Moreover, because clients tend to want "name" litigators arguing their cases, and because many of these litigators are recruited laterally, litigation associates have less opportunity to develop their skills and signal their quality to partners. ${ }^{316}$ These factors combine to make litigation one of the least likely routes to partnership for associates as a whole. $^{317}$ The prospects are worse for black associates, given the liklihood that certain clients will feel less comfortable entrusting their cases to a black lawyer. ${ }^{318}$ Black women probably face even steeper odds. ${ }^{319}$

Moreover, the pro bono and other small cases in which a black associate might be given major responsibility often do not generate the kind of positive feedback that might justify the risk and effort. Although many firms view pro bono projects as "training vehicles" for

314. Just under $25 \%$ of our Harvard survey respondents stated that the possibility of improving their marketability was an important reason for doing either litigation or pro bono work. Significantly, the percentage was 33\% for post-1986 graduates. See Appendix, Table 2a.

315. See Nelson, supra note 24, at 155 (arguing that litigation offers associates fewer opportunities for meaningful work or client contact).

316. Id.

317. Id. at 153 (reporting that litigation has one of the highest rates of associate attrition). The fact that black partners are concentrated in this area may simply have to do with the degree to which blacks go into this area in the first place.

318. See Knapp \& Grover, supra note 6, at 303 (reporting that recruiters for some firms express concern with how minority candidates will get along with the firm's white clients). Studies of bias in the court system repeatedly indicate that blacks and other racial minorities face discrimination in the courts. See, e.g., N.Y. REPORT, supra note 12, at 86-87 (reporting, inter alia, that black attorneys are often treated by judges and other courtroom personnel with less respect than their white counterparts); Scarnecchia, supra note 33, at 923 (reviewing the findings and state responses of task forces in Michigan, Washington, New York, Florida, and New Jersey). Cases in which a client wants to have a black lawyer may raise their own difficulties. See WiLkins, Race, Ethics, and the First Amendment, supra note 8, at 1042.

319. Consider the following incident involving a female associate, recounted by Elizabeth Chambliss:

We had a case where ... the star wituess from our side did not get along at all with the woman associate that was assigned to the case ....1 understand it was because she was a woman. He had this very macho sort of to hell with them all attitude. She was trying very carefully to be sort of a deliberate lawyer, and they just did not get along at all. And the case sort of rested on this guy's testimony, and knowing that he was going to have to be prepared for this trial by this woman, and then questioned on the stand by this woman, the chemistry was very important and I think the partner of his own initiative replaced her with a man.

Chambliss, supra note 7, at 109-10 n.23. 
young lawyers, ${ }^{320}$ this work is often not supervised closely by partners. Thus, even a good job frequently goes unnoticed. Should the case become a serious problem for the firm, however, it is the junior associate who is likely to be blamed. Moreover, as we indicated above, black lawyers who do significant amounts of pro bono work run the risk of being viewed as uninterested in the firm's paying clients, further reducing the probability that a partner will see the black associate as one worth training.

Finally, litigation is generally less stable than corporate work. Litigation is a very costly way for corporations to resolve their problems. Not surprisingly, corporate general counsel look for ways to reduce these expenses. When litigation projects end, the client is likely to go too (or at least to leave the litigation department and move to the corporate side). Moreover, although some kinds of litigation are repetitive (e.g., antitrust and securities) a good deal of the work done by junior associates involves mastering the facts of the case and doing research on fact-specific legal issues. Unlike mastery of the details of a particular kind of corporate transaction, this dispute-specific knowledge is less transferable to future cases. This makes it harder for a litigation associate to become expert in a particular substantive field and therefore to provide valuable services to the firm during lean economic times. ${ }^{321}$

\section{e. The Revolving Door}

Given this dynamic between the structural features of elite firms and the strategic choices of black lawyers, it is not surprising that the turnover rate among these associates appears to be especially high. Because they are less likely to receive the Royal Jelly of good training in core areas of the firm's practice, black lawyers legitimately fear that they will become flatliners with no future at the firm. ${ }^{322}$ As these lawyers increasingly focus on their lives after the firm, however, they simultaneously hasten their own departure. ${ }^{323}$ Not only is there likely to be a di-

320. See Paul Jaskunas, How to Make an "A," AM. Law., July-Aug. 1995, at supp. 20 (describing how Robert Borton, head of Heller, Ehrman, White and McAuliffe's public service program, "looks at pro bono work as training for associates").

321. Of course, this strategy also has risks, for example, if one's specialty is wiped out by a change in law.

322. Our survey records the predictable consequences. Fully $61 \%$ of our respondents stated that they had difficulty getting quality work assignments. Sixty-five percent, including $71 \%$ of the post1986 graduates, reported that the problem worsened over time. Appendix Table 2, Part B. As our model predicts, those who do not get quality work will eventually be dismissed by the firm; see also Emily Barker, Invisible Man. AM. LAw., May 1996, at 65, 67 (reporting that a senior partner at Washington, D.C.'s Katten, Muchin \& Zavis justified cutting a black associate's hourly billing rate from $\$ 185$ to $\$ 125$ per hour on the grounds that clients were unwilling to pay senior associate rates for the routine work the lawyer was performing).

323. In Member of the Club, Lawrence Otis Graham-a black, Harvard-educated, former Wall Street lawyer-suggests that for blacks in high-end corporate and law jobs, success can come only 
vergence between what is likely to make a black lawyer more marketable outside the firm (e.g., litigation training) and what leads to success within the firm (e.g., working for partners in the core areas of firm growth), but by contracting the time frame within which they must decide whether to stay or go, black associates often forfeit the opportunity to be "discovered" by partners with an interest in the firm's productivity. In a forthcoming study of successful minority managers in corporations, David Thomas concludes that even those who ultimately make it into the top ranks do not have the same smooth linear progression as their white peers. ${ }^{324}$ Instead, minority managers frequently suffer periods during which their careers stall, only to jump ahead when a senior manager notices their talents. This pattern of slow growth (and even periods of no progress) followed by relatively dramatic jumps in position is difficult enough in the general up-or-out world of elite law firms; it is virtually impossible in a world in which both firms and associates make important career decisions within the first one to two years.

There is, however, a way in which black lawyers have been able to replicate the success patterns Thomas outlines within the context of the current trend towards decreasing associate tenure. Ironically, it involves leaving the firm. A substantial percentage of all black partners in our data set worked in government (37\%), in-house counsel's office (28\%), and/or academia (11\%) before becoming partners. ${ }^{325}$ Similarly, in our survey, all four black Harvard graduates who had become partners in major firms left their first firms and went into either government (3) or a small firm (1) before becoming partners. ${ }^{326}$ This suggests that one way for black lawyers to accumulate the kind of human capital and name recognition that law firms look for when making partners is by going outside the firm where they may have better opportunities to develop their talents. ${ }^{327}$ The continuing success of this strategy, however, depends upon the criteria that firms are likely to employ in making

from being myopic about their work at that firm. Without this myopia, blacks focus rationally on departure, thereby undermining their chances for success. See Lawrence O. GRAham, MEMbER of THE Club: Reflections on Life in a Racially Polarized World 83-84 (1995).

324. See David Thomas, Breaking the Glass: The Making of Minority Executives in Corporate America (unpublished manuscript, on file with the author).

325. Appendix, Table 6.

326. Appendix, Table 2, Part A.

327. See, e.g., Berkman, supra note 19, at 1 (describing how Chicago's government offices are much better integrated than large private law firms-particularly at the supervisor/partner level). Joining a firm laterally, however, can also be a risky strategy--particularly if the lawyer comes in as a senior associate. Senior lateral associates must quickly develop good working relationships with partners and clients if they expect to make partner. For all of the reasons discussed in the text, black laterals may find this particularly difficult. See, e.g., Barker, supra note 322, at 68 (describing how a black senior associate "fell through the cracks" in part because he did not get good work from senior lawyers). 
partnership decisions. This brings us to the problems encountered by black partners.

\section{f. Unequal Partners}

There are now a handful of black partners at elite firms. ${ }^{328} \mathrm{Al}-$ though firms are quick to point to these modest gains as a sign of progress, the celebration is premature. In increasing numbers, black partners are doing the unthinkable-trading in their prestigious partnerships for a variety of other jobs ranging from in-house legal departments to partnerships in small minority firms. ${ }^{329}$ In this Section we argue that the three structural features of contemporary elite firms-high salaries, pyramiding, and tracking-are partly responsible for this attrition.

In the golden age, partnership in a major firm was the equivalent of academic tenure. Today, to keep their positions, partners must compete for both business and political allies. ${ }^{330}$ This competition takes place in two markets: outside the firm where individual partners seek to attract clients, and inside the firm where partners trade referrals and form political alliances. The structural characteristics outlined above make it more difficult for blacks to compete in both of these markets.

\section{i. The External Market}

Firms have always relied on partners to bring in business. In the golden age, however, most firms had room for partners who, although having few clients of their own, were excellent lawyers who "minded" the clients while the rainmakers were off making rain. ${ }^{331}$ With increasing leverage, higher associate salaries, and the breakdown of long-term client relationships, most firms feel that they can no longer tolerate such "unproductive" partners. As a result, the command that every partner bring in a substantial amount of business is now being rigidly enforced..$^{332}$

This structure disadvantages black partners in two ways. First, black partners are less likely to have personal contacts with corporate executives able to bring in matters of the size generally handled by cor-

328. See supra text accompanying notes 15-21.

329. See, e.g., Clarke, supra note 271 , at 29 (reporting that eight black partners had left major Chicago law firms in the preceding year); see Keeva, supra note 216, at 50 (stating that betwcen September 1991 and February 1993, fourteen minority partners left major law firms in Chicago).

330. See Galanter \& Palay, supra note 24, at 37; William C. Kelly, Jr., Reflections on Lawyer Morale and Public Service in an Age of Diminishing Expectations, in PuBLIC GooD, supra note 278, at $90,92-93$.

331. See Nelson, supra note 24, at 9 (categorizing partners as "finders, minders, and grinders").

332. See Generation Gap, NAT'L L.J., Nov. 21, 1994, at 20 (describing the firing of unproductive partners at Cadwalader, Wickersham \& Taft). 
porate law firms. ${ }^{333}$ Second, these lawyers will also have greater difficulty securing clients through the competitive marketplace. Just as law firms use high wages as a means of inducing effort without incurring substantial monitoring costs, corporate clients are prepared (albeit within increasingly strict limits) to pay high legal fees to insure that they get the best legal representation possible. Since even the most vigilant corporate general counsel will have difficulty assessing the quality of the services she receives, she has an incentive to hire firms-and increasingly, individual lawyers-with substantial reputations in the area in question. ${ }^{334}$ Although there will be some black superstar partners who meet this criterion, the average black partner is less likely to be considered the obvious and unassailable choice for receiving sensitive outside work.

\section{ii. The Internal Market: Getting the Franchise}

Black partners also compete for work from the firm's existing clients, including referrals from partners who receive inquiries about work outside of the contacted lawyer's area of specialization. Once again, this market is highly competitive, with many more qualified applicants than business to be divided. For the reasons suggested above, black partners are likely to have a more difficult time competing for this work than their white peers. Internal referrals are premised on notions of reciprocity, trust, and politics. If black partners have less access to business, a referring partner may prefer a white partner better able to return the favor in the future. If black lawyers have had fewer mentors within the partnership ranks as associates, they are less likely to be chosen as the person entrusted with one of the firm's major clients when they become partners. Finally, if black partners are not seen as powerful actors inside the firm, senior partners will be less likely to turn over clients for fear that these black lawyers will not be able to support them when the senior lawyers are less productive and influential.

333. See, e.g., Keeva, supra note 216, at 50,51 (describing the problems of black partners in Chicago). This situation may change as more blacks grow up in middle- and upper-income neighborhoods, attend elite schools, and move among the nation's movers and shakers. But see id. at 52 (arguing that, even when of equal economic status, minority lawyers must still overcome substantial systemic handicaps). Vincent Cohen, a partner since 1972 at Washington, D.C.'s Hogan and Hartson, states:

equating blacks and whites, regardless of economic status, shows a lack of understanding of life in America. "I sometimes wish that most white people could be black for a year and then return to being white," he says. "People of bad will would say, 'Yeah, I know it was hell, but good, let them catch hell.' But nobody would every say, 'Is it hell?' Everybody would know the answer to that one."

Id. See generally, DAwson, supra note 209, at 29-34 (discussing differences between middle-class blacks and whites).

334. See Keeva, supra note 216 , at 53 ("After all, corporate boards tend to be conservative, and no one wants to be blamed for sending business to the wrong attorneys"). 
Given these pressures, black partners are likely to continue to exit elite law firms in search of more stable options. Moreover, as we have previously noted, this attrition is likely to affect associate integration as well, since black partners will often spur firms to hire more black associates and act as mentors and role models for blacks that are hired. The net result, therefore, is that firms are hemorrhaging black lawyers from both ends. Unless this dynamic is reversed, the meager progress that has been made over the last several years is likely to come to a halt, or even be reversed. In the next Part, we examine what might be done to stop this trend.

\section{IV}

\section{The Solution(s)?: Finding Efficient Responses to} EFFICIENT DISCRIMINATION

Advocates of greater workplace diversity frequently point to projections indicating, in the words of Labor Secretary Robert Reich, that "women and minority men will make up $62 \%$ of the work force by the year 2005." ${ }^{335}$ These advocates hope such statistics convey an important message to corporate leaders (quoting Reich again): Maintaining a "glass ceiling" that inhibits the progress of women and minorities is simply "not good for business." 3336 Indeed, diversity advocates frequently assert that "most business leaders" are aware of the economic value of a diversified work force and therefore recognize that "they simply cannot afford to rely exclusively on white males for positions of leadership." ${ }^{337}$ In this respect, diversity proponents bear a striking resemblance to the conservative economists whose opposition to government intervention in the market they frequently condemn: both assume that firms have an economic interest in eradicating employment practices that exclude women and minorities from the work force.

In an important sense, we share this assumption. Elite law firms who use high wages, tournaments, and tracking will often lose the services of blacks who either are or could become outstanding lawyers. Unfortunately, our analysis of the reasons why firms utilize these strategies leads us to be more pessimistic than secretary Reich about whether elite firms will inevitably conclude that altering these practices in ways that might improve the employment prospects of black lawyers is so clearly

335. Message from the Chairman: Secretary of Labor Robert B. Reich, in Glass CeILINo Report, supra note 4, at 2; see also AMERICAN BAR Association CoMmission on OpPoRTunities for Minorities in the Profession, Increasing Diversity: The Retention \& Development of Minority Lawyers in Law Firms and Corporate Legal Departments tab A (Aug. 5 , 1993) (citing statistics in Work Force 2000, a 1987 Hudson Institute analysis of labor force trends and projections) [hereinafter INCREASING DivERSITY].

336. Glass CeILING REPoRr, supra note 4, at 2.

337. Id. 
"good for business." So long as firms continue to generate both a small number of high quality partners and a steady supply of hardworking associates, they have little economic reason to alter the way they structure their business simply to change the demographic composition of tournament winners. ${ }^{338}$

Those who wish to break this cycle must therefore alter the incentives that firms presently face if they wish to convince these institutions that abandoning their currently efficient employment practices is "good for business." Proposals to alter these incentives can usefully be divided into five categories: litigation under Title VII or other similar anti-discrimination statutes; race-neutral institutional reforms, such as formal training or mentoring programs; education initiatives such as diversity training; demand-side initiatives designed to generate corporate business for black lawyers; and supply-side initiatives, including such traditional affirmative action remedies as goals and timetables for hiring and promoting black lawyers. Assessing the overall merits of each of these proposals is beyond the scope of this Article. Instead, we describe the implications of our analysis for each initiative.

\section{A. Anti-discrimination Law ${ }^{339}$}

Many commentators have documented the difficulty of applying Title VII and other similar anti-discrimination laws to high-level jobs in which quality judgments are inherently subjective. ${ }^{340}$ Neither disparate treatment nor disparate impact analysis is well suited to rooting out the kind of adverse employment practices we describe. For the most part, the lawyers who prefer average whites to average blacks have no discriminatory animus as that term has been traditionally defined. Indeed, other things being equal, they would probably prefer to hire and/or

338. This hard reality may help to explain why progress in recruiting women into the associate ranks has so far failed to produce a corresponding percentage of women partners. With $40 \%$ of the graduating classes at most law schools being female, firms have no choice but to hire women if they want to satisfy their expanding need for associates. See Abdon M. Pallasch, No Place Like Home for Recruiting Minorities and Women, CHI. LAW., May 1995 (reporting that nearly half the graduates of Chicago law schools last year were women, 677 out of 1,455); Foster, supra note 291, at 1637 (reporting that the percentage of women graduating from law schools has risen from under $9 \%$ of all students in 1970 to between $40 \%$ and $50 \%$ today). So long as there are two or three men among the new class of associates with the skill and stamina to become outstanding partners, however, there is no necessary reason why a firm must choose to invest scarce training resources in its women associates. See Note, Why Law Firms Cannot Afford to Maintain the Mommy Track, 109 HARv. L REv. 1375 (1996) (reporting that a 1994 National Association of Law Placement Report finding that only $13 \%$ of large law firm partners are women). The Note argues that self-interested firms have reasons to work to close this gap. We examine some of the reasons that this might be true below.

339. For a detailed account of why anti-discrimination law is unlikely to prevent firms that employ high wages and tournaments from utilizing employment practices that disadvantage minority workers, see Charny \& Gulati, supra note 9, at 53-61.

340. See, e.g., Barbara J. Flagg, Fashioning a Title VII Remedy for Transparently White Subjective Decision Making, 104 Y ALE L.J. 2009 (1995); Foster, supra note 291, at 1668. 
promote (and indeed probably have hired and promoted) superstar blacks over average whites. Nor are the institutional practices that tend to keep blacks off the training track likely to be condemned under a disparate impact analysis, given that changing these practices would involve a fundamental restructuring of the way corporate firms do business. Not surprisingly, when they have been presented with claims of this type, courts have generally refused to second guess the subjective decision making of partners in the absence of clear evidence of discrimination. ${ }^{341}$

Moreover, even if one could design a Title VII remedy that could reach this conduct, it is not clear that legal intervention of this kind would be either appropriate or effective. The requirement that law firms justify objectively every choice between candidates when one is black and the other white would place a substantial burden on firm decision makers. ${ }^{342}$ In fact, it is difficult to state exactly how that burden should be discharged. At the hiring stage, the inherently subjective and provisional character of judgments about the quality of a given candidate would make it difficult for firms to develop a set of objective criteria capable of credibly determining which candidates are in fact better qualified. Indeed, as we have argued, the fact that firms place substantial weight on objective signals such as law school status and grades in the visible part of the recruiting process already disadvantages black candidates. Precisely because they are objective, these criteria send the reassuring-but largely false-message that those who are being selected are demonstrably better than those who are not. Getting firms to recognize that these signals are only loosely correlated with either valuable substantive job skills or the personal qualities that are likely to make a candidate an effective lawyer is therefore an essential step in creating greater opportunities for black candidates. If successful, however, this project is likely to make the recruiting process even more subjective as firms weigh a broader range of information (for example, leadership in community organizations or the ability to overcome obstacles) when evaluating candidates.

Of course, to the extent that firms employ objective criteria at the visible stage, anti-discrimination law will help to ensure that they do so fairly. However, if we also make the plausible assumption that most white law students do not want to be associated with a law firm that "visibly" discriminates by preferring white candidates with lower credentials to blacks whose signals are objectively higher, this is also the

341. See, e.g., Ezold v. Wolf, Block, Schorr \& Solis-Cohen, 983 F.2d 509 (3d Cir. 1992), cert. denied, 114 S. Ct. 88 (1993) (refusing to overturn a decision to deny a woman partnership in the absence of clear evidence of discrimination); see also Foster, supra note 291, at 165-71.

342. See Flagg, supra note 340 (advocating that employers bear such a burden of proof). 
kind of discrimination that is most likely to be disciplined by the market. $^{343}$

Applying objective standards to the partnership decision would be even more complex. By the time a black associate comes up for partner, she may very well be less "qualified" precisely because she has not received the Royal Jelly that would allow her to develop these qualifications. In order to be effective, therefore, the requirement that firms objectively justify choices between average whites and average blacks would have to be applied to every staffing and mentoring decision made throughout the firm. Even if such a requirement were not per se unadministrable, which it probably is, it would undermine the kind of collegiality and informal working relationships that are essential elements of the practice of law.

Nevertheless, it is important that law firms do not feel that they are immune from anti-discrimination laws. The threat of liability undoubtedly encourages firms to pay more attention to their employment practices than they otherwise would. ${ }^{344}$ This vigilance may help to prevent some of the more egregious instances of discriminatory conduct. In addition, discrimination lawsuits can sometimes make "visible" the largely "invisible" process by which firms choose partners.

Consider the recent case involving Lawrence Mungin, a black Harvard Law School graduate who successfully sued the Washington, D.C. office of Katten, Muchin \& Zavis for "constructively discharging" him on the basis of his race. ${ }^{345}$ At the visible level, the firm's decision not to consider Mungin for partnership seems unassailable. When Mungin requested that he be evaluated along with the other Katten, Muchin associates in his class, he was working primarily on projects that would normally have been handled by second and third year associates. Not

343. White candidates who disapprove of overt racial discrimination will lower their ranking of firms that engage in this practice. As we indicated, this can hurt both recruiting (to the extent that the firm develops a bad reputation among law students) and business development (since clients may also not want to be associated with a discriminating firm, and in any event, are also sensitive to a firm's prestige ranking among law students). See Richard Epstein, Forbidden Grounds: The Case AGAINST EMPLOYMENT DiscriminATION LAW (1992) (arguing that the market will correct for overt discriminatory practices that are not otherwise efficient). However, given that law students face substantial obstacles to acquiring accurate information about even the visible aspects of the process (for example, the short "institutional memory" of law students and the low level of communication across schools), this market mechanism can easily break down. This is one of the many reasons why we reject Epstein's prescriptive claim that anti-discrimination law is both unnecessary and harmful.

344. Given low monitoring, partners will often be unaware of discriminatory actions taken by other partners or associates, particularly if those actions affect persons outside the firm. The threat of discrimination lawsuits - even ones that ultimately fail (since the firm will still incur both litigation and reputational costs)-gives firms an incentive to devote more resources to monitoring than they otherwise would be inclined to do.

345. See Barker, supra note 322 , at 66 . 
surprisingly, Mungin's managing partner informed him that it would be impossible to make him a partner based on his current performance. ${ }^{346}$

Mungin's lawsuit revealed, however, that a number of actions by the firm plausibly contributed to Mungin's inability to get the kind of work that would have allowed him to demonstrate his partnership potential. According to press accounts, when Katten's Washington office lost most of its bankruptcy business (Mungin's area of specialization) he was told he would receive work from the firm's bankruptcy lawyers in Chicago. The work never arrived. ${ }^{347}$ Nor was Mungin included in departmental meetings in either Washington or Chicago. ${ }^{348}$ Nor was he given a performance review during his first eighteen months with the firm, even though Katten, Muchin's policy was to review every associate twice a year. ${ }^{349}$ Instead, in words attributed to Mungin's supervising partner, he simply "fell through the cracks," never becoming successfully integrated into the firm's practice or culture. ${ }^{350}$

Whether all of this constitutes proof of discriminatory intent within the meaning of the anti-discrimination laws is subject to dispute. The firm clearly went out of its way to recruit Mungin and chose not to lay him off (as it did other associates) when the Washington office lost most of its bankruptcy business. ${ }^{351}$ Nevertheless, by shining light on the normally invisible world of law firm staffing and work assignment decisions, Mungin's case may encourage firms to pay more attention to whether black associates are getting access to challenging and productive work. ${ }^{352}$

346. See id. at 68 (quoting Mungin's supervisor as stating "I told him ... that he wasn't doing partner-level work" and "I couldn't imagine the [partner review committee] would have passed him through").

347. See id. at 67.

348. See id.

349. See id. at 68.

350. See id.

351. See id. at 71 .

352. See id. at 67 (suggesting that the lesson from Mungin's case is that "[f]irms must take steps to keep, nurture, and promote their minority hires from the day they walk in the door" and quoting a special counsel in an elite New York firm as speculating that "[n]ow management is going to have to, just as in the sexual harassment area, think about its strategy in developing associates and working with associates"). It is important not to overstate this effect. Mungin's case is in many respects unique. Not only did Mungin have superstar credentials (e.g., Harvard undergraduate and law school, fluent in Russian), but he came in as a lateral with a demonstrated record of success at other law firms. This, combined with the promises that were made to him when he was hired, made it easier for him to demonstrate that he was not being given the training and opportunity necessary to prove his abilities than would be the case for the average black associate who is flatlining at his first flrm. Indeed, the primary lesson from Mungin's case is that blacks with superstar credentials may still encounter problems on their way to becoming successful law firm partners. See id. at 71 (noting that one of the jurors believed that Mungin was penalized because he was more qualified than many other Katten lawyers). 
There may, however, be other consequences. As Mungin's case suggests, the threat of litigation probably decreases a black associate's chances of being fired. ${ }^{353}$ Firms face both defense and reputation costs from being accused of discrimination even if the suit is ultimately unsuccessful. ${ }^{354}$ These costs, in addition to the firm's desire to have at least one senior black associate "visible" to the outside world (even if he was "invisible" to the firm's partners when it came to assigning work) ${ }^{355}$ may have been what stopped Katten from firing Mungin when a white seventh year associate who could only be billed out at second or third year rates probably would have been let go.

The fact that anti-discrimination law decreases a black lawyer's chances of being fired will have mixed effects on her opportunities at the firm. Given this phenominon, firms may be less likely to hire average black associates, and/or more inclined to flatline those who are hired, thereby inducing them to leave "voluntarily." From the black associate's perspective, however, a reduction in the probability of being fired may help to counteract the sub-optimally high fear levels discussed im Part III. ${ }^{356}$

For all of these reasons, it is not surprising that anti-discrimination cases are rarely brought in this area and even more rarely won. ${ }^{357}$

353. See id. at 71 (quoting Katten's counsel as arguing to the jury that "[t]he reality is, they didn't fire him because he was black. Given the verdict, 1 feel that they should have fired him").

354. See Richard C. Reuben, Suing the Firm, 81 A.B.A. J., Dec. 1995, at 68, 72 (discussing the costs to a firm of having an insider/associate sue them for discrimination). Actually bringing a discrimination suit, however, is costly to the plaintiff. Since other firms will have little information about the merits of the black employee's claim, they are prone to be sympathetic to the firing firm's position (particularly given that both firms probably follow similar policies and practices). As a result, they are likely to view the fired employee as a "troublemaker," as well as someone who is in the unacceptable category. In a low-monitoring world, such strong negative signals can be disastrous to a black lawyer's future job prospects. In discussions with black lawyers who have either brought or contemplated bringing suit, we have found that the danger of being branded a troublemaker has been a major consideration in their decisions. See also, Barker, supra note 322 , at 70 (reporting that the Mungin is currently working as a contract lawyer for the S.E.C. making $\$ 14$ per hour).

355. See id. at 66 (describing Mungin as an "invisible man" inside the firm).

356. Theoretically, this litigation effect might decrease a black lawyer's fear levels to such a point that she begins to slirk. The fact that black associates know that partners can convey this information to future employers informally (even if the associate is not fired), combined with the signficant obstacles that blacks face in the lateral job market even when they aren't burdened with additional negative signals, provide a powerful disincentive to engage in this kind of opportunistic behavior.

357. See Ramona L. Paetzold \& Rafael Gelu, Through the Looking Glass: Can Title VII help Women and Minorities Shatter the Glass Ceiling?, 31 Hous. L. Rev. 1517, 1528-43 (1995). There are, however, probably more discrimination suits than the judicial record would lead one to believe. In light of the reputational interests outlined above, both potential plaintiffs and firms have an incentive to settle discrimination law suits quickly and quietly. Although each side has an interest in testing the other side's willingness to put its reputation on the line, eventually the parties are likely to find it in their interest to reach a confidential settlement. (One black lawyer involved in such negotiations described them as a "game of chicken" in which the firm waited until the lawyer demonstrated that he was prepared to risk his reputation by actually filing suit before the firm offered 
Moreover, even if courts were more hospitable to such lawsuits, ${ }^{358}$ the practical consequnces of applying anti-discrimination law in this area might be less than the proponants of this strategy tend to believe. Although increasing Title VII liablity may make firms more concious of these issues, experience with other employers highlights how firms can structure their internal practices so as to blunt the effects of antidiscrimination law. ${ }^{359}$ We return to this issue below..$^{360}$

\section{B. Institutional Reform}

In Part II, we argued that the key difference between succeeding at a corporate firm and flatlining is training. Formal training and mentoring programs therefore seem to be the ideal solution to the institutional dynamics we describe. Moreover, since these programs are available to every associate, they sidestep many of the problems connected with race-conscious remedies such as affirmative action. ${ }^{361}$ There are, however, limitations on what these programs are likely to accomplish.

The widespread rush to institute formal training programs confirms two key elements of our model: that entering associates know almost nothing about the practice of law, and that it is no longer cost effective for firms to train the vast majority of associates by giving them meaningful access to good work and supervision. ${ }^{362}$ Despite the fanfare with which firms announce their new training efforts, it is clear that those wishing to succeed must still gain access to the traditional training track. Although lectures, simulations, and drafting exercises can help associates develop technical skill, they cannot teach judgment. Nor can they build the kind of mentoring relationships that are crucial to an associ-

a lucrative settlement conditioned on the lawyer's express promise that the entire matter would remain confidential). Private settlements dccrease the value of anti-discrimination law as an informational tool.

358. See St. Mary's Honor Center v. Hicks, 113 S. Ct. 2742, 2749 (1993) (holding that plaintiffs must demonstrate not only that the employcr's justification for favoring a white worker is pretextual, but also that the justification hides a discriminatory motive).

359. See Lauren B. Edelman, Legal Ambiguity and Symbolic Structures: Organizational Mediation of Civil Rights Law, 97 AM. J. of Sociology 1531, 1554-56 (1992); see also Lauren B. Edelman, Legal Environments and Organizational Governance: The Expansion of Due Process in the American Workplace, 95 AM. J. of Sociology 1401 (1990).

360. See infra text accompanying notes 378-381.

361. See Sunstein, supra note 74 (describing the problems associated with affirmative action and other remedies and arguing that policy makcrs should have a preference for race neutral policies).

362. See, e.g., Richard N. Feferman, Associate Training: Raising Lawyers for Fun and Profit, LAW Prac. MGMT., July/Aug. 1993, at 28, 30-31 (dcscribing changes in the legal profession that make traditional associate training programs obsolete); Herman, supra note 313, at 1 (quoting a name partner in a major Chicago firm as conceding that "no longer ... can lawyers rcly just on being mentored or counseled by lawyers for whom they always work"). 
ate's success at the firm. ${ }^{363}$ Nor will they provide client contact. Put simply, what associates need is good work that will help them to develop their legal and personal skills. Formal training programs cannot substitute for this kind of real experience.

More importantly, from the perspective of integrating corporate firms, there is no guarantee that formal training programs will work to ameliorate the problems faced by black associates. Ironically, the fact that the best formal training programs are in litigation may further lure black associates into investing in this risky (from the perspective of success in the firm) area of practice. ${ }^{364}$ Moreover, these programs say nothing about who will actually get the type of work associates need to succeed. If all associates go through formal training, partners must still choose which ones to put on the kind of important assignments that develop an associate's skills. While it is possible that a black associate can use formal training exercises as a platform to promote her skills, these programs are often too brief and ineffective to disrupt the work assignment patterns outlined in Part II.

Formal assignment systems could breaking these patterns. As firms have become more bureaucratized, they have attempted to rationalize their assignment and evaluation systems. ${ }^{365}$ Although the firm's main concern is the efficient allocation of resources, formal assignment and evaluation systems can also provide associates with some protections against the vagaries of the intra-firm assignment market.

These formal systems, however, often do not work well. Powerful partners routinely bypass the system to grab superstar associates, leaving the assigning partner (who often is not a powerful partner) ${ }^{366}$ to divide routine or unimportant projects among the unlucky average associates who remain in the pool. ${ }^{367}$ Similarly, formal evaluation systems, while potentially providing valuable information and feedback, can also act as a diversion that allows partners to refrain from giving real feedback in the course of the working relationship. We suspect that this phenome-

363. Some firms have attempted to supplement their formal training programs with formal mentoring programs. See Steven Keeva, Good Act to Follow, A.B.A. J., Mar. 1995, at 74. The artificial constraints of such relationships, however, hinder their effectiveness. Moreover, to the extent that they do not involve real work, they can never substitute for the kind of guidance and experience being received by those on the training track. Despite these constraints, however, meaningful relationships can blossom through these programs, which sometimes give blacks access to powerful partners in the firm whom they otherwise would not get an opportunity to meet.

364. See Herman, supra note 313 , at 20 (noting that litigation lends itself to the kind of hands-on training exercises that work well in a formal training program).

365. See generally NELSON, supra note 24, at 159-89 (describing the work structure of modern law firms).

366. Firms frequently do not want to divert the energies of powerful partners, who are most often rainmakers, into what is often seen as a ministerial duty.

367. See Chambliss, supra note 7, at 95-96 (giving accounts of partners "poaching" good associates). 
non particularly disadvantages blacks, since white partners may either feel less comfortable giving genuine negative feedback to black associates or, conversely, more comfortable allowing their background preconceptions to guide their assessments when talking to their peers. ${ }^{368}$

For all these reasons, formal training, assignment, and evaluation systems are unlikely to rectify the most important problems facing black associates. ${ }^{369}$ This is simply another example of the painful truth that it often takes race-conscious remedies to rectify the continuing deleterious effects of America's history of racial oppression. ${ }^{370}$ The last three responses all proceed along these lines.

\section{Diversity Training}

A growing number of elite law firms have hired diversity consultants. ${ }^{371}$ These consultants come into a law firm and talk to associates and partners about coping with a diverse workforce. Diversity consultants attempt to educate lawyers about their colleagues, by (a) alerting them to differing and sometimes incorrect perceptions they may have about each other, (b) pointing out the possibility that some minority lawyers believe that they are being discriminated against, and (c) illustrating how stereotypes can often result in discriminatory behavior ${ }^{372}$ One diversity consultant we heard speak boiled this all down to "communication."

At first, these efforts seem ideally suited to counteracting the problems we describe. In Part III, we argued that the preference for average whites over average blacks is due in part to the fact that white partners often hold stereotypical beliefs about black lawyers that lead them to be

368. Although we have no basis for comparison, the fact that $64 \%$ of the respondents to our survey of black Harvard Law School graduates stated that they were told of criticisms about their performance during the formal review process that were not mentioned at the time the work was performed provides some support for this intuition. See Table $2 \mathrm{~b}$. Negative feedback of this kind is far less useful than constructive criticism at the time the work is performed.

369. See Chambliss, supra note 7, at 123 (finding that, with the exception of a formal departmental structure, bureaucratization is negatively correlated with law firm integration). Moreover, to the extent that these institutional reforms superficially appear to respond to the problems of unequal access and differing standards of evaluation, they may actually impede progress by discouraging firm leaders from doing more. Id.; see infra text accompanying notes 371-376 (discussing diversity consultants and structuring).

370. For a theoretical defense of this point in the context of moral argument, see Wilkins, Two Paths, supra note 8.

371. See Dimitra Kessenides, Dealing With Diversity, AM. LAw., July-Aug. 1994, at 40. As far as we know, there are no concrete studies on the effects of diversity training. Therefore, this section relies on anecdotal evidence. Both of us have talked with numerous lawyers who have been through these programs, and one of us has participated in two diversity training sessions specifically designed for elite firms.

372. See Herring, supra note 302 , at 7.

373. See Communication in the Workplace (promotional leaflet for Organizational Training, Inc., 1995) (on file with authors). 
unduly pessimistic about their future performance. Moreover, since we also claim that such beliefs are often unconscious, a program designed to highlight these attitudes and their effects should help firms to understand the obstacles that impede black progress.

Whether diversity training actually fulfills this promise, however, depends upon both its content and the process by which it is conducted. Anecdotal reports suggest that diversity consultants tend to concentrate on exposing how racist comments, unintended slights, and cliquish social patterns marginalize black lawyers. ${ }^{374}$ Although undoubtedly important, our analysis suggests that this is not where the most pressing problems lie. For example, less than one third of respondents to our survey indicated that what they considered to be explicit racist comments were made in their presence, and of those who heard such remarks, less than $20 \%$ listed the incident as a major reason why they left their firm. ${ }^{375}$ A higher percentage of respondents (56\%) stated that they did not feel welcome in the informal social networks within the firms. ${ }^{376}$ Nevertheless, almost half of these lawyers $(46 \%)$ did not consider this a major factor in deciding whether to leave the firm. When combined with the $44 \%$ of respondents who did feel welcome, the percentage for whom social relations are a serious problem drops to less than one third. ${ }^{377}$

Moreover, there is a long history of firms and courts subtly transforming informal grievance procedures, such as diversity training, into mechanisms for suppressing conflict. ${ }^{378}$ For example, affirmative action officers inside corporations often do not provide workers with important procedural protections and are frequently biased in favor of management. Nevertheless, courts are increasingly willing to give the determinations of these officers preclusive (or nearly preclusive) effect in litigation and to penalize plaintiffs who do not utilize these "voluntary"

374. Interviews conducted by the authors at three elite New York firms that have hired diversity consultants.

375. Appendix, Table 2, Part C. See also, Barker, supra note 322, at 69 (noting that Mungin did not argue that there was overt racism at Katten). In any event, if white lawyers actually hold consciously racist views, it is unlikely that diversity training (or anything else for that matter) will dissuade them from these beliefs. As we indicated above, we do not believe that intentional racism is widespread among elite firm lawyers. We therefore are inclined to believe that even statements that could fairly be interpreted as "racist" will most often be the product of something less than conscious racism.

376. Appendix, Table 2, Part C.

377. Id. Twenty out of sixty-six respondents (30.3\%) stated that they had left their firms in part because they felt unwelcome in informal social networks.

378. See Richard L. Abel, The Contradiction of Informal Justice, in THE Politics of INFoRmaL Justice 267, 304-07 (Richard L. Abel ed., 1982) (describing how informal procedures are often used to "cool out" clients and suppress disputes). 
mechanisms. ${ }^{379}$ Notwithstanding the good intentions of its proponents, diversity training may suffer the same fate. Diversity consultants are hired by the firm and deliver their reports and recommendations directly to firm managers. Training sessions are often conducted with both partners and associates present. When consultants interview associates privately, their comments about the firm are frequently reported (generally "anonymously") to partners. ${ }^{380}$ Not surprisingly, many black associates and partners are reluctant to discuss their true feelings under these conditions. ${ }^{381}$ To the extent that firm leaders hear no serious complaints, they may falsely conclude that racial issues are not a serious problem in their firm. Moreover, if courts conclude that a diversity consultant's report is discoverable in a subsequent discrimination lawsuit, firms may structure their use of consultants so as to avoid producing negative information about firm practices--or perhaps to provide affirmative evidence of their lack of discriminatory intent. Given the development with respect to affirmative action offices, courts appear eager to accept this kind of evidence.

Finally, diversity training is likely to be most effective if it concentrates on structural impediments to black advancement such as the ones we have described. ${ }^{382}$ Changing these structures, however, is difficult. Supplying firms with information about how their practices affect the career prospects of black lawyers can provide an important impetus for change. Nevertheless, firms need more than "communication" to convince them to change practices that have proved profitable for those lucky and skillful enough to find themselves at the top of the pyramid. $^{383}$ Demand creation initiatives are designed to provide a profitmaximizing reason for change.

379. See Elizabeth Chambliss, Title VII as Displacement of Conflict (1996) (unpublished manuscript, on file with author); Lauren Edelman, Howard Erlanger, Jonathan Lande, InternalDispute Resolution: The Transformation of Civil Rights in the Workplace, 27 LAw \& Soc'Y Rev. 497 (1993).

380. Given the small number of black associates, preserving anonymity is virtually impossible.

381. For example, one of us was told by a black lawyer at an elite firm that the night before the diversity consultants were scheduled to interview black associates, the firm's two most senior African American attomeys called all of the other black lawyers to tell them not to reveal their true feelings or experiences during the interview.

382. Indeed, we hope that this paper will make some modest contribution to these efforts.

383. We suspect that at least some firm leaders are already aware that their hiring and promotion practices can produce arbitrary decisions about which lawyers succecd at the firm. See. e.g., Feferman, supra note 362, at 28.

Years ago, some lawyers got the idea for the pyramid scheme that forms the skeleton for the modern law firm. They figured out they could hire a bunch of young lawyers to do the legal research they hated doing, and palm off their most unpleasant matters on them. They paid these junior-level attomeys chicken feed and made huge profits off their labor. The cream rose to the top, the firm dumped the sediment from the bottom, and the whole process Id. would repeat itself. 


\section{Stimulating Demand}

In 1988, the American Bar Association initiated the Minority Counsel Demonstration Program. The Program's goal is straightforward: "to create opportunity for minority attorneys to become fully integrated in the profession." 384 In order to accomplish this goal, the Program encourages participating corporations to retain minority firms and to ensure that minority partners in majority firms do some of their legal work. ${ }^{385}$ By stimulating demand for the services of minority lawyers at large law firms, the Program seeks, inter alia, "to increase the number of minorities they recruit, hire, retain and promote to partnership." ${ }^{386}$

The ABA's program, and other similar initiatives around the country, ${ }^{387}$ expressly target one of the most promising avenues for getting firms to care about diversity-the bottom line. If black lawyers have unique access to particular kinds of lucrative corporate business, firms that fail to recruit and retain these lawyers will suffer a competitive loss. The essence of this strategy is, therefore, to turn every black lawyer into a superstar whose rainmaking potential provides firms with a rational reason for preferring these lawyers to average whites.

By almost any measure, the ABA's Program is a success. In its first three years, 133 corporations, 39 major law firms, and 21 minorityowned firms participated. ${ }^{388}$ All together, minority attorneys in both large firms and minority-owned firms collected more than $\$ 100$ million in fees from corporate participants. ${ }^{389}$ Moreover, the number of minority associates at the fifteen majority firms filing reports in 1991 increased by over $50 \%$ during the three years that the program was in operation, and the number of minority partners grew by $57 \% .{ }^{390} \mathrm{Al}-$ though the Project does not break these results down by race, ${ }^{391}$ the numbers are impressive. ${ }^{392}$

384. American Bar Association Commission on Minorities in the Profession, Into the Mainstream: Report of the Minority Counsez Demonstration Program I988-199I, at 6 (1991) [hereinafter Program RePORT].

385. Id.

386. Id.

387. For example, the Bar Association of San Francisco has helped to establish the California Minority Counsel Program, which is similar to the ABA's program. See S.F. REPORT, supra note 33, at 5 .

388. Program REPORT, supra note 384, at 5.

389. Id. at 10 .

390. Id. at 15 (noting that the average number of minority associates grew from 8.4 to 12.8 and the average number of partners increased from 2.5 to 3.9 ).

391. This is another example of the difficulty, described in Part III, of gathering data on black lawyers.

392. For example, the growth rate in minority associates and partners under the ABA's program is substantially larger than the average growth for all minorities in large firms during this period. See 
Nevertheless, there is reason to be skeptical about the ability of this or any other similar program to affect substantially the opportunities of the majority of blacks in corporate firms. The Program's mission statement provides an important clue to its limitations. In setting out its goals, the Commission states that one of the major obstacles "impeding the full participation by minorities in the profession is the perception that corporate users of legal services do not desire that minorities handle their legal affairs." ${ }^{393}$ The Program seeks to counter this perception by encouraging corporate counsel to write letters to their outside law firms making it clear that they would like minority lawyers to work on their matters and requesting information about whether the firm is complying with its requests. ${ }^{394}$ This framework, however, assumes that corporate leaders already recognize that diversity is "good for business." Although perceptions are important as we have already noted, the presumption that this is the primary problem faced by black lawyers is unwarranted.

The claim that diversity is good for a corporation's bottom line has substantial force in certain sectors of the economy. For example, companies that sell consumer products, trade internationally, or (because of affirmative action guidelines) do substantial business with the government have long recognized the importance of having a workforce that reflects the needs and concerns of their customer base. It is therefore not surprising, as we noted in Part I, that blacks have made substantial inroads in heavily regulated industries such as communications and insurance, that Asian-Americans are well represented in firms that do business in Asia, or that Proctor \& Gamble (which markets household products) has one of the best records of hiring and promoting women. ${ }^{395}$

Just because a corporation sells its products to a diverse population of customers, however, does not necessarily mean that it will want its lawyers to be diverse as well. When AT\&T is considering a new joint

Jensen, supra note 12, at 1,28 (reporting only slight changes in the percentage of minority attorneys in surveyed law firms between 1981 and 1989).

393. Program Report, supra note 384, at 4 (emphasis added).

394. For example, the General Counsel of General Motors sent a letter including the following language to all of the law firms doing GM business:

A matter of great concern to me, and the entire bar, is the disappointingly slow pace at which minorities are being integrated into our legal profession, particularly at the practice level at which we must engage.... I therefore ask you to be certain that minority lawyers in your firm able to provide service at the requisite level be included among those who represent G.M. In addition, I am confident that you agree with me that we must make certain we are doing all we can to introduce additional able minority attorneys into our respective organizations.

Letter from Harry I. Pearce (Feb. 29, 1988), reprinted in INCREASING DiverSITY, supra note 335, at tab E.

395. See generally GLASS CEILING REPORT, supra note 4. 
venture agreement, for example, it wants lawyers who know how to operate in the complex world of strategic planning and corporate finance, a world that is still overwhelmingly white and male. The fact that the lawyer who has the skills and connections to operate effectively in this world may not "reflect" or "understand" the concerns of the company's customer base is likely to be of little concern to company officials. Given this dynamic, it is not surprising that most corporate participants in the ABA Program do little more than send the same letter every year "requesting information" and dole out a few small projects that are often below the pricing structure for most major firms. ${ }^{396}$

Advocates of demand creation strategies argue that this dynamic is changing. In support of this claim, they point to two developments in the corporate marketplace. First, advocates note that an increasing number of positions inside corporate counsel offices are being filled by women and minorities. These new purchasing agents, the advocates contend, will be more receptive to hiring minority lawyers than were their predecessors. ${ }^{397}$ Second, they argue that growing black political power on the federal, state, and local level will increase demand for black lawyers.

There is merit in both of these claims. ${ }^{398}$ Anecdotal evidence suggests that black in-house lawyers are more likely to take an active interest in ensuring that work is fairly distributed to black lawyers inside firms. ${ }^{399}$ Similarly, black political clout has frequently been translated into opportunities for black lawyers. ${ }^{400}$ While neither development is

396. Interviews conducted by Professor Wilkins. This reality reflects the fact that the Program was originally set up to benefit minority law firms. Indeed, one of the unintended effects of the Program is to encourage black partners to leave elite firms for minority-owned enterprises that can more effectively compete for this and other similar corporate work. See Keeva, supra note 216, at 50-51.

397. See Giesel, supra note 272 , at $799-800$ (arguing that as more women become in-house counsel, women in firms may enjoy increased "rainmaking" ability).

398. See Chambliss, supra note 7, at 133-41 (reporting a positive correlation between client demographics and law firm integration). Significantly, Chambliss found that not every demographically connected variable was significant for every group. For example, she concluded that the presence of a foreign office was positively correlated witl the number of Asian lawyers but not the number of blacks. See id. at 129. As Chambliss suggests, this is probably due to the fact that there are few foreign offices in Africa or the Caribbean. Id. This is yet another example of the danger of making generalizations across minority groups.

399. See American Bar Association Commission on Opportunities for Minorities in the Profession, Survival in Corporate Law Firms and LaW Departments in an INCREASINGLY COMPETITI VE ENVIRONMENT (Aug. 1995) (panel of minorities in corporate counsel offices discussing their efforts to channel work to minority lawyers).

400. Thus, when Harold Washington became Chicago's first black mayor, the number of black lawyers doing substantial business with the city substantially increased. Interviews by Professor Wilkins with various black partners in Chicago. Similarly, the Congressional Black Caucus was largely responsible for the inclusion of Section 1216 in the Financial Institutions Reform, Recovery and Enforcement Act of 1989, which mandates the Office of Thrift Supervision to "ensure inclusion, to the maximum extent possible, of minorities and women ... including providers of legal services, in 
likely to change the demand for black corporate lawyers overnight, ${ }^{401}$ both demonstrate that as more companies have a specific reason for hiring black lawyers, demand will increase.

This evidence, however, also underscores the connection between integration and the demand for minority lawyers. Initiatives in the last category aim to achieve this goal directly.

\section{E. Affirmative Action}

Throughout much of this analysis, we have assumed that firms make no special efforts to hire and promote black lawyers. We did this for two reasons. The first is methodological. As we indicated in Part II, many commentators claim that affirmative efforts are unnecessary since market forces will drive out policies and practices that disadvantage blacks. Our analysis demonstrates that this claim is unlikely to be true for elite law firms.

The second reason for bracketing affirmative efforts in the earlier analysis is empirical. Although virtually every firm claims to be making special efforts to recruit and promote blacks, it is unclear how often these programs actually reach beyond competing for black superstars. Certainly the numbers do not suggest that firms are engaged in a wholesale effort to hire average blacks over average whites. ${ }^{402}$

Nevertheless, at least since the 1970s, many elite firms have hired black lawyers whose rankable signals were lower than the average credentials of the firm's white associates. Indeed, many firm leaders claim that they always hire black candidates when their signals are roughly comparable to those of their white peers. Moreover, the new task forces established in the late 1980s to promote diversity in law firms have made traditional affirmative action remedies such as goals and timetables for hiring, and sometimes promoting, minority lawyers a central

all contracts entered into by the agency." Jose O. Seda, Hiring of Women and Minority Lawyers for Bank and Thrift Bailout Work Is the Law, BANk. \& Thrifr L. BuL., Aug. 1992, at I.

401. Those who make optimistic predictions based on these changes frequently overlook a number of important constraints. For example, as we argued in Part III, corporate counsel are under tremendous pressure to hire lawyers whose "merit" is beyond question to protect themselves against the possibility that something might go wrong. This pressure may be particularly acute for blacks who face being accused of favoritism if they hire a black lawyer over an equally prominent white lawyer. In conversations about the Program, several black partners have mentioned that this dynamic substantially limits the ability of black corporate counsel to give good work to black lawyers.

Similarly, the Supreme Court's recent decisions striking down various government set-aside programs highlight the risks of tying one's success to the political arena. See Adarand Constructors, Inc. v. Pena, 115 S. Ct. 2097, 2117 (1995) (holding that race-based federal set-aside program must satisfy strict scrutiny). The fact that many of the lawyers who were hired by the City of Chicago when Harold Washington was mayor lost this business when he died underscores this danger. Interviews with Professor Wilkins.

402. See Davis. supra note 15 (critiquing the "hard to find good help" rationale for the limits of current law firm recruiting efforts). 
feature of their agendas. ${ }^{403}$ These programs appear to have increased the presence of black lawyers in the elite firms. ${ }^{404}$

Despite this success, affirmative action programs in this area are in danger. Affirmative action is now a controversial topic in the United States. ${ }^{405}$ From a doctrinal standpoint, recent cases cast doubt on the legality of voluntary affirmative action programs that make choices between equally qualified applicants solely on the basis of race. ${ }^{406}$ In addition, critics on both the right and the left raise questions about the fairness, efficiency, and efficacy of making employment decisions on the basis of race. ${ }^{407}$

We do not propose to resolve this complex dispute. Our analysis, however, does shed light on three of the most common objections raised to voluntary affirmative action programs in elite institutions: that affirmative action lowers standards, that it reduces worker effort, and that it stigmatizes its intended beneficiaries. Although these arguments may have force in other contexts, they do not provide persuasive grounds for abandoning the kind of affirmative action programs in use at elite firms.

403. One of the most ambitious programs has been established by the San Francisco Bar Association. In 1989, the Association adopted a goal that participating firms have $15 \%$ minority associates and $5 \%$ minority partners by December 31, 1995. By December of 2000 , the goal is to raise these percentages to $25 \%$ and $10 \%$, respectively. See S.F. REPORT, supra note 33 , at 1 . By comparison, the Los Angeles County Bar Association is committed to hiring each year a number of minority lawyers that is equal to $10 \%$ of the total number of attorneys hired during the years between 1992 and 1996. See Faye A. Silas, Bar, Law Firms Develop Statements of Goals to Increase Hiring. Retention and Promotion of Minority Lawyers, BAR LEADER, July-Aug. 1993, at 21, 24. New York has pledged to achieve a level of $10 \%$ minority associates by 1997 . Adams, supra note 50 , at 4 . Many other groups either have established similar goals or have urged firms to hire and promote minority attorneys.

404. For example, in a study of large San Francisco firms, the number of black associates (105 to 122) and partners (21 to 32 ) rose significantly in the first three years of the Bar Association's minority hiring program. See S.F. REPORT, supra note 33, at 8 . Similarly, a survey of New York law firms conducted after the Association of the City of New York adopted voluntary goals and timetables showed increases in hiring and promotion rates for blacks as well as an increase in retention. See Adams, supra note 50. See also, Davis, supra note 15 (linking recent increases in the number of minority associates to these programs).

405. See, e.g., B. Drummond Ayres Jr., Califomia Acting on Affirmative Action, N.Y. TimEs, Mar. 26, 1995, at 24; B. Drummond Ayres Jr., California Governor Vows to Cut Affirmative Action, N.Y. TImes, June 1, 1995, at A15; Molly Ivins, Race Does Matter, Boston GloBe, Apr. 19, 1996, at 19; Jeff Jacoby, Counting by Race, Boston GloBe, Apr. 25, 1996, at 21, Gene Kratz, Less Diversity at B-Schools, Bus. WK., Apr. 29, 1996, at 26.

406. See Don Munro, Note, The Continuing Evolution of Affirmative Action Under Title VII: New Directions After the Civil Rights Act of 1991, 81 VA. L. Rev. 565, 582-85 (1995). See also, Hopwood v. Texas, 78 F.3d 932, cert denied, 116 S. Ct. 2580, 64 USLW 3868 (1996).

407. See, e.g., Ian Ayres, Pursuing Deficit Reduction Through Diversity: How Affirmative Action at the FCC Increased Auction Competition, S. CAL. L. Rev. (forthcoming 1996) (manuscript at 60-65, on file with author) (describing the competing positions on affirmative action). 


\section{Standards}

Affirmative action opponents frequently claim that such policies inevitably reduce standards. The argument sounds in efficiency. If employers hire workers with lower siguals, the argument goes, the quality of the final product will suffer. Even when taken on its own terms, the standards critique misconstrues the dynamic of the law firm recruiting process. In Part III, we argued that stereotypes and unconscious bias lead firms to favor whites over blacks with functionally equal qualifications and to discount the signals of black superstars. To the extent goals and timetables or other affirmative recruiting measures give firms a reason to detect and prevent practices that favor whites, and therefore increase the incentives of black lawyers, these measures will in fact serve rather than weaken the goal of "standards."

Moreover, the standards critique rests on an unrealistic view about both the content of the signals used by elite firms and their relationship to job related skills. Even if we confine ourselves to the criteria that seem to play the largest role in the recruiting process-law school status and grades - the standards critique ignores the tremendous growth in the size and quality of the law school applicant pool over the last few decades. Compared to the "golden age" when most of today's law firm partners went to law school, competition for law school placesparticularly at elite schools-has become much more intense. ${ }^{409}$ Given this change, the claim that hiring a black student who has survived this competition and secured a place at a good law school lowers the quality of a firm that has many partners whose own academic performance while in college might not have been sufficient to have earned them a place in that same school today is flatly inconsistent with the timeless value that those who endorse these kinds of arguments generally give to standards.

408. By tying a law firm's reputation to making progress on hiring and promoting blacks, goals and timetables give firms a reason to pay attention to how their lawyers choose between black and white candidates in the average range. Assuming, as the advocates of standards must, that firms care about getting the applicants with the best signals, the easiest way for firms to meet this goal and protect their reputation is by ensuring that the actual skills of black applicants are fairly appraised. Since the prior practice of preferring average whites causes no efficiency loss, this addicd reputational interest gives firms an incentive to monitor these decisions more closely than they otherwise would.

409. See Note, Daniel R. Hansen, Do We Need The Bare Exam: A Critical Examination, 45 Case W. Res. L. Rev. 1191, $1235 \mathrm{nn} .131-32$ (1995) (documenting the rising quality and quantity of the law school applicant pool). Needless to say, a similar phenomenon has been happening in Universities, prestigious high schools, and even in elementary schools. See Bruce Webber, The Harvard Class of '00. N.Y.T. MAG., April 27. 1996, at 44 (describing the intense competition to get into Harvard College and reporting that even with affirmative action, the blacks who are admitted have superstar credentials). 
This last point underscores the loose connection between signals such as grades and law school status and the skills that go into making a good lawyer. The argument that hiring blacks with lower credentials will hurt productivity assumes that there is a direct relationship between these signals and quality. As we argued above, however, no such direct relationship exists. As a result, it is not surprising that firms consistently demonstrate by their actions that they are uninterested in making the kind of refined judgments about skills upon which the standards critique ultimately rests. Not only do firms fail to seek out information about a candidate's skill (as opposed to her signal) level during the recruiting process, but when it has been economically profitable, they have shown themselves to be willing to jettison standards arguments altogether. Consider the explosion in the use of paralegals at large firms. ${ }^{410}$ In the "golden age" firms maintained that keeping track of documents, drafting letters and motions, and routine legal research were the "practice of law" and therefore could only be handled by highly trained (and expensive) associates. Today, much of this work is done by people who have no legal education whatsoever.

Once again, the point is not that judgments about skill are impossible or that the traditional standards are meaningless. As we have argued, firms have an incentive to seek out superstars, no matter how imperfectly measured, and to protect themselves against unacceptable workers. In the middle, however, they are (at least on efficiency grounds) indifferent since they know that differences among candidates in this range are not worth the trouble of investigating. ${ }^{41}$ Given what we know about the work these associates will do when they arrive at the firm, this middle/average range is much broader and much less differentiated than the standards critique would lead one to believe. So long as the black lawyers being hired under an affirmative action program come from this middle/average range, any claim that the quality of the firm's work will diminish, lacks credibility.

Indeed, goals and timetables like the ones established by the San Francisco bar may help firms to avoid any potential reputational loss from being seen by their clients or competitors as "lowering standards" to recruit blacks. By creating a visible competition for blacks (among others), these programs establish a new signal by which firms can be ranked alongside their competitors. Paradoxically, even in a world where some find the standards critique persuasive, the firm that hires the most black lawyers ought to be the one whose reputation among these skeptics suffers the least. Thus, firms such as San Francisco's Morrison

410. See supra note 192.

411. See Selmi, supra note 49 (making a similar argument about slight differences in employment test scores). 
\& Foerster and New York's Cleary, Gottlieb, Steen \& Hamilton (two firms that have dramatically increased their minority hiring) can credibly claim that they are among the "best" firms for black lawyers. This, in turn, should signal to their clients, their competitors, and the general population of law students, that the black lawyers hired by these firms are likely to be the best in the available pool. Moreover, in addition to solving the firms' collective action problem regarding the standards issue, these policies also signal to black law students that they have a realistic chance of being hired and promoted by an elite firm. This highlights the issue of investment.

\section{Effort: Lowering the Price of the Ticket to the Tournament $t^{4 / 2}$}

Opponents of affirmative action assert that it reduces socially beneficial incentives for both black and white employees. Specifically, the argument is that because employees have to exert lower amounts of effort to obtain jobs or promotions, they have reduced incentives to work hard and invest in human capital. ${ }^{413}$ This argument is implausible in the elite law firm context. Indeed, our analysis suggests that the opposite is more likely to be true. At present, black lawyers at elite firms have very little chance of becoming partners. As a result, the average black associate has inadequate incentives to invest in human capital strategies that might lead to success at the firm. If affirmative action provides the average black associate, who today faces a low probability of success, with a somewhat greater probability, this can only increase her incentive to work. Moreover, none of the programs we are discussing would in any way guarantee that any particular black lawyer will be hired or become a partner. Since black lawyers still know that they face countless barriers to success even with affirmative action, they have plenty of incentive to continue to work hard and invest in human capital. 414

412. We borrow the phrase from James Baldwin's masterful collection of essays. See JAMEs W. Baldwin, The Price of The Ticket: Collected Non-Fiction, i 948 -i 985 (1985).

413. Glenn Loury describes an economic model where affirmative action results in supervisors/employers holding blacks to lower standards in order to satisfy institutional pressures to promote and hire blacks. In tum, he argues, these lower standards result in rationally lower effort levels by blacks. See LourY, supra note 36 , at 114. Ward Connerly, the black member of the University of California's Board of Regents who led the charge against affirmative action at the University, also makes this argument. See William H. Honan, Regents Prepare for Storm on Affirmative Action, N.Y. TIMES, July 19, 1995, at B7.

414. See Jonathan S. Leonard, The Impact of Affirmative Action Regulation and Equal Employment Laws on Black Employment, 4 J. EcoN. PERSP. 47, 61 (1990) (finding little negative effect of affirmative action on productivity in the context of federal contractors); Jonathan $S$. Leonard. Antidiscrimination or Reverse Discrimination: The Impact of Changing Demographics, Tille VII, and Affirmative Action on Productivity, 19 J. Hum. Resources 145 (1984) (same). One might argue that black superstars face reduced incentives since they know that they have a good chance of being hired and making partner even without affirmative action. However, accounts by even those black superstars who are skeptical about the value of affirmative action once again point in the 
To the extent that our conservative colleagues perceive the problem with affirmative action to be that it reduces incentives to invest in human capital (specifically skills), our model speaks to their concerns. In the sectors of the economy where signals are relatively uncorrelated with skill, that worry should be put to rest. Associates are choosing some combination of signals and skills to help them both get a ticket to the tournament (where the price of the ticket is the level of signals the firm requires) and then have a chance of winning the tournament (where initial skills are necessary to help one be chosen by a partner for the training track). If as a result of affirmative action, blacks have to spend less of their scarce resources on purchasing the ticket, they can use that time to acquire skills to win the tournament. ${ }^{415}$ This result, as conservatives should agree, is a benefit both to individual blacks and to society as a whole. ${ }^{416}$

Arguments about reduced incentives for whites are similarly unconvincing. Here, the claim is that if whites see their chances of success reduced as a result of affirmative effort for blacks, they will no longer have as much of an incentive to exert effort. ${ }^{417}$ Given the institutional dynamics inside elite law firms, this theoretical possibility is unlikely to develop into a serious problem. In light of the enormous rewards associated with corporate law practice, it is not plausible that whites will forego the opportunity to compete for these jobs simply because a firm has committed to hiring blacks to fill ten, twelve, or even fifteen percent of its needs. From the perspective of average whites, this reduction in their chances of receiving a lucrative offer from an elite firm is minimal in light of the high odds facing average white candidates in the absence of affirmative action. ${ }^{418}$ Indeed, to the extent that affirmative action has any effect, it may increase the effort exerted by whites to secure one of these coveted places. ${ }^{419}$ In addition, to the extent that hiring blacks with

opposite direction; these superstars believe that they have had to work twice as hard as their white colleagues to overcome the stigma that they do not deserve their superstar status. See, e.g., CARTER. supra note 228. We retum to the issue of stigma below.

415. The only scenario in which black student or associate would not transfer her resources to investing in skills is where she is already confident enough of winning the partnership tournament that she believes that she needs no more skills-an unlikely eventuality, especially for a risk-averse individual.

416. See, e.g., Weiss, supra note 88 (suggesting that excessive reliance on education as a signal may encourage socially wasteful investment).

417. Cf. J. Hoult Verkerke, Note, Compensating Victims of Preferential Employment Discrimination Remedies, 98 YALE L.J. 1479 (1989) (arguing in favor of monetary compensation for whites whose chances of success are lowered as a result of affirmative action).

418. Opportunities available to superstar whites will not diminish at all, since they will still be given preference over both average blacks and average whites.

419. Ian Ayres argues that affirmative action and the resultant higher barrier for whites to succeed would in fact produce higher effort levels from white workers because of increased competition. See Ayres, supra note 407, at 63; see also Andrew Schotter \& Keith Weigelt, 
fewer traditional signals convinces firms to abandon or relax these hiring standards for all candidates, some average whites whom firms might not otherwise consider will have a better chance of being hired. Finally, once they join the firm, white associates will be motivated by the same combination of fear and future rewards that currently produces high effort levels among all associates. If a firm detects a white associate shirking, the fear of an anti-discrimination lawsuit will not keep it from firing her and hiring an easily available replacement.

\section{Stigma}

Evidence that affirmative action does not lower standards or reduce effort would be cold comfort if these programs actually ended up hurting their intended beneficiaries. Those who press the stigma argument make just this claim. The logic is straightforward and compelling. If it is widely known that at least some significant number of blacks have benefited from affirmative action, employers will rationally discount any particular black candidate's credentials by the amount they think she has benefited. ${ }^{420}$

Given our analysis, this is a serious concern. In a world where decisions on the assignment of projects are made on low amounts of information, the perception that blacks on average have lower skills will hurt them. The danger is that in deciding which projects to give to white associates and which ones to give to black associates, partners will choose to give routine projects to the black associates and analytical/training related ones to the white associates. This, as we have documented, results in blacks perceiving less of a future at the firm and adopting strategies that end up justifying the partners' decisions in not choosing them. ${ }^{421}$ In short, affirmative action could end up exacerbating the problems black associates are already facing at elite firms. ${ }^{422}$

Asymmetric Toumaments, Equal Opportunity Laws and Affirmative Action: Some Experimental Results, 107 Q.J. Econ. 511 (1992).

420. For a discussion of statistical discrimination, see David A. Strauss, The Law and Economics of Racial Discrimination in Employment: The Case for Numerical Standards, 79 GEo. LJ. 1619 (1991). A related stigma argument is that affirmative action causes blacks to suffer excessive amounts of self-doubt, since they are unsure of their own qualifications for a job. While this may be true, we think it is relatively unimportant when compared to the problem of the employer doubting the employee. After all, employees know their own skill levels better than anyone else. For a discussion of this problem, see LouRY, supra note 36 , at 238-41.

421. Perceiving a reduced set of opportunities vis-a-vis one's competitors reduces incentives to work. See Richard B. Freeman, LABOUR MARKETS IN ACTion 128 (1989) (suggesting that youths who perceived their employers as discriminatory were more likely to be absent from their jobs); see also Rowlett v. Anheuser-Busch, Inc., 832 F.2d 194, 202 (1st Cir. 1987) (recognizing how discriminatory behavior by an employer can influence the incentives of an employee and result in negative behavior on the part of the employee, such as a high absence rate).

422. The harm is even worse for bona fide black superstars. Their superstar qualifications are doubted and discounted because of the possibility that they were achieved as a result of affirmative 
The solution, however, is not to abandon voluntary affirmative action in hiring, but to extend it to decisions regarding the choice of associates for projects and other internal firm decisions. Designing affirmative measures that will ensure that black associates have meaningful access to the training track is a complex task. Goals and timetables for promotion as well as hiring are a good start, but standing alone, they are unlikely to change the way that partners assign work or decide whom to mentor. If firms are truly serious about improving the prospects of their black lawyers, they must implement policies that change the incentives of partners. For example, companies such as Proctor and Gamble and AT\&T rate their managers in terms of their success in promoting the firm's diversity goals and weigh these ratings in setting compensation and determining promotions. If elite firms were to institute policies of this kind, partners would have concrete incentives to insure that blacks make it onto the training track.

\section{Conclusion: Choosing A New Path}

We return, therefore, to where we began. In Part II, we rejected the traditional economic assumption that firms that maintain employment policies that disadvantage black workers will necessarily be driven from the market. We argued that this optimistic projection is unlikely to be true in the context of elite law firms. These organizations have developed a series of interconnected institutional practices to reduce monitoring costs that insulate them from the consequences of permitting practices that disproportionately disadvantage black lawyers. In Part IV, we argued that there are measures that firms could take to alter this state of affairs. The question remains, however, why should firms adopt these corrective measures? From the outset, we have insisted that analyzing the institutional structure of firms and the incentives that those structures create for black lawyers is a crucial part of any comprehensive explanation of the problem of law firm integration. But if high wages, pyramiding, and tracking are "efficient," what incentive could firms possibly have to change these practices? More to the point, by linking diversity and efficiency in this way, have we simply given firm leaders a potent excuse for rationalizing the absence of black lawyers as simply an unfortunate but inevitable consequence of their Darwinian struggle for survival?

action. Hence, unlike white superstars, black superstars face an extra burden of proof to show that they really are superstars. Understandably, some of these black superstars resent this extra burden and find it harmful. The question is whether this harm outweighs the benefits of affirmative action for the majority of blacks who are not superstars. See T. Alexander Aleinikoff, A Case for RaceConsciousness, 91 Colum. L. REv. 1060, 1091 n.148 (1991) (stating that the costs of stigma notwithstanding, blacks remain overwhelmingly in favor of affirmative action). 
Although these arguments might seem powerful from the perspective of traditional law and economics theory, ${ }^{423}$ we nevertheless believe that they trade on false (or at least highly exagerated) claims about what it means to say that a particular institutional structure is "efficient." Standard law and economics theory often speaks as if the institutions we see are the inevitable result of an evolutionary process in which inefficient structures and practices are continually challenged and undermined through the process of competition by those that are more efficient. As a result, proponents of this evolutionary model tend to assume that the institutions that we see must be efficient, since if they were not, they could not have survived. ${ }^{424}$ The analogy is to biology, where, it is assumed, nature selects for those adaptations most suited to survival.

As Professor Mark Roe has recently argued, however, this evolutionary model is not only bad law, it is bad biology. ${ }^{425}$ Even in the natural world, the process of evolutionary development is far more complex and haphazard than the linear model endorsed by many law and economics theorists. Thus, species tend to develop through a series of punctuated equilibria rather than on some preordained path towards optimality. According to this view, species are formed quickly in response to environmental factors and thereafter remain relatively stable, not adapting to incremental changes that do not threaten species viability. Only when there is a crisis will this state of affairs be disturbed, in which case the species will either be destroyed or a minority with a particularly adaptive trait will survive and once again congeal, freezing both its "efficient" and "inefficient" traits until the next crisis. ${ }^{426}$

Moreover, as Roe argues, evolutionary thinking in law and economics must be modified further to account for additional aspects of the development of social institutions that have nothing to do with whether a firm's particular structural features are efficient in terms of the contemporary environment. All social institutions develop at specific moments in time and in response to particular conditions. This creates two problems for traditional evolutionary models. First, conditions existing at the time an institution is formed will influence the functioning of that institution far into the future, often in unintended

423. For example, when writing from a traditional law and economics perspective, one of us has come to a more pessimistic conclusion about the possibility of successfully integrating low monitoring workplaces through a process of incremental institutional change. See Charny and Gulati, supra note 9, at 36-38.

424. The most famous example of this kind of reasoning is the claim by some of the original proponents of law and economics theory that the common law is efficient. See, e.g., George L. Priest, The Common Law Process and the Selection of Efficient Rules, 65 J. LEgAL STUD. 65 (1977); Paul Rubin, Why is the Common Law Efficient?, 65 J. Legal STUd. 51 (1977).

425. See Mark J. Roe, Chaos and Evolution in Law and Economics, 109 Harv. L. Rev. 641 (1996).

426. See id. at 663 . 
and unexpected ways. ${ }^{427}$ Second, once an institution starts down a particular path, the costs of changing structures and practices that may have been well adapted to the prior conditions will often seem too great even in cases where everyone agrees that a new path is better suited for the current reality. ${ }^{428}$ Worse yet, in those instances in which the path that has been chosen has become entrenched, institutional actors may not even be able to imagine alternative paths that might be more efficient.

Collectively, these three truths about the development of social institutions should make us hesitate before declaring that the policies and practices that we see today are not only the most, but perhaps even the only, "efficient" adaptation to contemporary conditions. ${ }^{429}$ Although institutions that have survived and prospered in a reasonably competitive market cannot be too inefficient, it is also likely that they will incorporate pockets of inefficiency that have been carried along with more efficient practices, as well as vestigial structures and ways of thinking that are largely the result of historical accidents and are no longer particularly well suited to today's (let alone tomorrow's) reality.

The story we have told about the institutional practices of elite law firms fits the pattern Roe describes. In Part II, we argued that high wages, pyramiding, and tracking are rational responses to the problem of monitoring lawyer quality. These practices, and more importantly the manner in which these institutional structures operate to disadvantage black lawyers, are, however, the product of the historical evolution of law firms and this country's long and tragic history with "the problem of the color line.".430

427. See id. at 642. Roe adapts this insight from Chaos theory.

428. See id. at 643-44. He adapts this insight from theories about path dependence.

429. In a recent series of lectures at Harvard Law School, Professor Roberto Unger made a similar point about what he refers to as the "institutional fetishism" of traditional American liberalism and the "structural fetishism" of the left. Unger argues that Americans tend to assume that our basic political institutions represent the best possible-and therefore the last-compromise among the competing values at stake in a representative democracy. As a result, these institutions are exempt from the fundamental experimentalism that has otherwise characterized this nation's attitude towards solving social and political problems. For its part, the American left tends to see these same institutions, as well as new ones that might be developed, as the result of an overarching and largely fixed economic and political superstructure that inevitably shapes social institutions into predictable forms. Unger rejects both of these fetishes. The first ignores the fact that our existing institutions are the product of historical traditions and contingencies, and may very well be less suited to contemporary conditions than plausible alternatives. The second underestimates society's ability, when animated by a vision of the future and an energized politics, to alter the basic character of social life through incremental changes in the structure and functioning of institutions. Although we may not always agree with Unger about how such a transformation might take place, his basic rejection of the tyranny of the present is as important an antidote for the satisfaction of the center and the fatalism of the left as Roe's analysis is for the biological determinism of the right.

430. The reference is to W.E.B. Dubois' famous and prophetic statement that "the problem of the Twentieth Century is the problem of the color line." See W.E.B. Dubors, The Souls of Black Folk 13 (Donald Gibson ed., 1989). 
Elite law firms developed their basic character in the latter years of the nineteenth century. Following Cravath's example, firms began recruiting "the best young men" from the country's "best" law schools to work as salaried associates for a period of time at the end of which they would either become partners or leave the firm. ${ }^{431}$ This model was well adapted to the circumstances that confronted Cravath and other similar firms at the turn of the century. ${ }^{432}$ Given the scarcity of high quality elite firms, long-term institutional relationships between firms and clients, and the knowledge asymmetry between lawyers and clients during this period, firms could pass the cost of training young lawyers on to their clients. ${ }^{433}$ Moreover, the social practices and mores of the time made it acceptable, if not necessarily optimal, for firms to confine their recruiting efforts to a narrow range of white male Protestant graduates from a few law schools. The gap, in terms of the quality of the students and faculty, between elite schools such as Harvard and the majority of regional and local schools was probably large. At the same time, the homogeneity of the professional and business class in the United States during this period increased the economic importance of social capital (such as family background and Protestant sensibilities) relative to job skills. Finally, when it came time for those who did not make partner to leave, there were plenty of jobs with similar wages (in "lesser" firms, in government, with clients, etc.) for them to choose from.

Virtually all of these underlying conditions have changed during the last twenty years. Predictably, elite law firms have attempted to adapt to these new realities. These adaptations, however, do not deviate substantially from the path laid down by Cravath more than a century ago. Thus, high wages, pyramiding, and tracking are all ways for firms to respond to changes in the market for clients and labor within the context of an institutional structure that is still characterized by a division of labor between "partners" and "associates," an "up-or-out" system of associate career development, and a subtle, but nevertheless powerful, presumption in favor of white male graduates of elite law schools. Although some firms have instituted policies that deviate from each of these traditional practices, the original path continues to shape the debate over the future of elite firms.

431. See generally GALANTER AND PALAY, supra note 24 (describing the historical development of elite firms).

432. See Gilson and Mnookin, Coming of Age, supra note 63, at 571 \& n.14 (describing the advantages of the Cravath model of associate careers).

433. See Ronald Gilson, The Devolution of the Legal Profession: A Demand Side Perspective, 49 MD. L. REv. 869 (1990) (positing a recent decline in information asymmetry between lawyers and clients). 
There is, however, no reason to believe that these traditional institutional practices are more efficient than others that might have been developed to respond to the problems elite firms presently face. Accounting firms, for example, confront many of the same difficulties as law firms. Yet these organizations have developed in ways that differ materially from the practices of elite law firms. The large accounting firms typically have many more categories of employees, a substantially longer "partnership" track, and no (or very relaxed) "up-or-out" policies. ${ }^{434}$ Similarly, when we look overseas, we see that the American model of elite law practice is still more the exception than the rule. In most of Europe, for example, even the best law firms remain small, pay relatively low wages, and are characterized by intense training and supervision. More importantly, although there are a growing number of European "mega-firms," frequently modeled on their American counterparts, even these institutions are likely to develop institutional structures and practices that differ substantially from their U.S. counterparts. ${ }^{435}$ For example, many European firms do not bill for their services by the hour, instead relying on a combination of retainers, flat fees tied to the value of the project, and incentive compensation formulas. They also tend to have both more categories of employees and lockstep compensation systems for partners. ${ }^{436}$

The fact that accounting firms and European law firms have developed differing, but no less successful solutions to the monitoring problems inherent in delivering professional services casts doubt on the claim that the institutional practices of elite firms constitute the sole efficient response to these questions. ${ }^{437}$ This institutional comparison is particularly significant in light of the fact that elite firms increasingly compete with accounting firms and European mega-firms in a broad range of corporate transactions. Indeed, according to some knowledgeable observers, it is precisely because elite law firms are locked into a path that leads them to offer increasingly specialized legal services at ever higher prices that these institutions will eventually lose out to international accounting firms such as Arthur Anderson in the competition

434. See Marc Galanter \& Thomas Palay, The Many Futures of the Big Law Firm, 45 S.C. L. REv. 905, 912 (1994) ("The Big Six [accounting firms] are generally characterized by taller hierarchies and considerably higher associate-to-partner ratios than the traditional big law firms.").

435. See David M. Trubek et al., Global Restructuring and the Law: Studies of the Institutionalization of Legal Fields and the Creation of Transnational Arenas, 44 CASE W. RES. L. REV. 407 (1994) (arguing that European "global firms" will develop along lines that differ in important ways from American firms).

436. See John Flood, Megalawyering in the Global Order: The Cultural, Social and Economic Transformation of Global Legal Practice, 3 lNT'L J. Legal PROF. 169, 177-78 (1996).

437. See Roe, supra note 425 , at 646 (making a similar argument with respect to the differing strategies for corporate control in the United States and Japan). 
to be the premier providers of legal and business services to corporate clients. ${ }^{438}$

America's long history of discrimination against blacks exercises a similar hold on the problems we discuss. As we argued in Part III, this history is partly responsible for the fact that high wages, pyramiding, and tracking are likely to have an especially adverse effect on the career opportunities of black lawyers. Slavery set this nation on a path in which it was necessary to portray blacks as mentally, emotionally, and spiritually incapable of self-determination. Almost a generation after the last de jure remnants of this vicious system were put to rest, the stereotypes and predispositions that can be traced back to this ignoble past continue to shape race relations in this country. One of the legacies of this history is that discussions about race inevitably proceed from a set of premises that make it difficult for many Americans to recognize forms of racial disadvantage other than the kind of intentional racism that characterized this nation's past.

There can be little doubt that America would be better off if it could escape the grip of this racialized past. Although institutions such as elite law firms can adapt to these inefficiencies by instituting policies that insulate them from the economic consequences of discrimination, the long-term effects on American society of failing to integrate "highlevel" jobs cannot possibly be good. As we acknowledged in Part I, many Americans place a positive value on diversity, preferring to live and work in spaces where they can interact with blacks. Even those who do not would arguably benefit from the diminution of social conflict that arguably would flow from spreading social resources more equitably.

Although deviating from the path of the past is never easy, the turbulent nature of both the market for corporate legal services and the current debate over the continuing significance of race paradoxically provides us with an opportunity to reassess and reshape our traditional understandings. Modern evolutionary theory suggests that it in times of crisis that species are most likely to alter their basic developmental path. There can be little doubt that elite corporate firms are in such a period. Numerous reports document that lawyers "in every type of practice and at every level of seniority, are increasingly dissatisfied with their professional lives." ${ }^{439}$ A good deal of this dissatisfaction can be traced to the very structural mechanisms-high wages, pyramiding, and

438. See Karen Dillon, Accounting for Success: How Arthur Anderson Quietly Became the Most Successful Law Firm in the World, AM. LAw., March 1994, at 30; see also David H. Maister, The One-Firm Firm: What Makes it Successful, Sloan MGMT. Rev., Fall 1985, at 3.

439. Deborah K. Holmes, Learning from Corporate America: Addressing Dysfunction in the Large Law Firm, 31 Gonz. L. REv. 373, 375-76 (1995/96) (citing statistics). 
tracking - that firms have developed to cope with the rising pressures of global competition. ${ }^{440}$ In other words, as we have emphasized from the outset, most white lawyers are also adversely affected by the current structure of corporate practice.

To address these problems, commentators and firm leaders have begun to advocate a fundamental restructuring in elite firm practice. Reforms currently under discussion include replacing hourly billing with fixed or incentive-based compensation systems, instituting "Total Quality Management" (TQM) programs designed to foster better client services through communication and teamwork, and replacing partnership (and the current "up-or-out" system) with a more rationalized management structure under the control of professional administrators. $^{441}$ If adopted, these structural reforms would alter the institutional dynamic we describe. In a world of fixed fees, flatlining would become a cost to the firm as opposed to a potential source of profit. TQM's emphasis on teamwork and localized decision making would make it more difficult to leave black associates out of developmental relationships while at the same time giving firms an incentive to recruit lawyers with a broader range of interpersonal skills than those reflected in such traditional siguals as elite school status and high grades. Finally, replacing overworked partners with professional administrators who have the authority and experience to implement long-range management policies would help to ensure that formal work assigument and mentoring policies are applied fairly and uniformly throughout the firm.

The explosion in information technology opens up additional possibilities. The path that has led to the current pyramidal structure that characterizes today's elite corporate firms can be traced to the fact that at the turn of the century, most of the clients of these firms were themselves centralized, hierarchical, and vertically integrated. Today, as a result of the information revolution, these clients are more likely to be characterized by a flat, decentralized management structure that incorporates telecommuting employees, a global distribution system, and multiple interlocking networks and alliances. ${ }^{42}$ At the same time, elite firms now have access to an unprecedented array of technology to assist them in the performance of their work. ${ }^{443}$ The combination of these forces creates the potential for new "efficient" firm structures. Thus,

440. See id. at 379-87 (attributing lawyer disfunction to a "squeeze" between rising costs-most notably high associate salaries-and reduced revenues produced by growing competition that results in longer hours, less training, and diminished loyalty and collegiality).

441. See id. at 387-410 (describing initiatives).

442. See Val D. Hornstein, Commuting to the Law Office on the Information Superhighway: Virtually There, 6:1 STAN. L. \& POL'Y REv. 99 (1994).

443. See Ethan Katsh, Digital Lawyers: Orienting the Legal Profession to Cyberspace, 55 U. PitT. L. Rev. 1141 (1994). 
some have argued that lawyers can now form "virtual law firms" in which attorneys using state-of-the-art technology form loose relationships and alliances with other attorneys to perform particular client projects or to open up new areas of business. ${ }^{44}$ Others assert that twenty-first century firms are more likely to resemble "diamonds" rather than pyramids, with a large number of experienced middle-level lawyers doing the bulk of the work. ${ }^{445}$ Another possibility is that firms will move towards an "hourglass" structure in which technology would provide senior lawyers direct access to information, thereby reducing the need for middle-level lawyers to process and summarize data while increasing the need for junior lawyers and other paraprofessionals who would put the raw information in a form that senior lawyers could use. .46 $^{46}$ All of these alternative structures would substantially alter the recruitment and retention issues we described in Part III.

The current "crisis" in legal education also has the potential to transform key elements of the dynamic we described in Part III. In recent years, the bar has expressed increasing dissatisfaction with the perceived disjunction between what is taught in the academy and the skills that lawyers need to survive in the "real world." 447 One way that law schools might respond to this pressure is by creating new courses that allow students to integrate experiential and theoretical knowledge. ${ }^{448}$ These new curricular offerings would provide students with additional avenues to demonstrate their competence, first to their professors, and second (through either the grading process or the generation of tangible products) to employers. In addition, to the extent that these new courses are more closely tied to actual lawyering skills, employers have an incentive to value them as more than simply a "signal" of basic intelligence or competency. ${ }^{449}$

444. See Bruce Mitchell, Using Collaborative Computing Tools to Build Virtual Legal Dream Teams, Legal MGMT., May/June 1995, at 28.

445. Gary Griffith, Techshow 95: Dramatic Change in the Practice of Law. Info. TodaY, June 1,1995 , at 22 .

446. See Joseph L. Kashi, Technology and Economics Are Changing How You Practice Law, Law Prac. MGMT., Nov./Dec. 1994, at 48.

447. See MACCRATE REPORT, supra note 97. This pressure is in part a tacit acknowledgment of our claim that law firms (and other legal employers) no longer have the time or the inclination to train lawyers themselves.

448. See Nancy L. Schultz, How Do Lawyers Really Think?, 42 J. Legal Educ. 57, 73 (1992) (advocating providing students with a variety of "teaching methodolog[ies], personal visions, [and] interdisciplinary concepts" as a solution to the integration of lawyering theory and skills). For a description of one attempt to accomplish such a synthesis, see David B. Wilkins, Redefining the "Professional" in Professional Ethics: an Interdisciplinary Approach to Teaching Professional Ethics, 58 LAW \& CONTEMP. PRoBs. 241 (forthcoming 1996).

449. For example, the State University of New York at Buffalo School of Law has proposed radically restructuring its curriculum "to equip [graduates] to work like lawyers" as well as to "think" like lawyers. See The New Curriculum: University at Buffalo School of Law (Dean's Office description, on file with California Law Review). 
Finally, even the much publicized crisis in American race relations might provide the shock that allows this nation to develop new and better pathways between blacks and whites. A series of recent events, many played out in the legal arena, make it painfully clear that blacks and whites frequently see the world through different eyes. ${ }^{450}$ Although divisive, these events also focus attention on some of the reasons why blacks and whites perceive the world so differently. In the hands of thoughtful observers, the insights gleaned from this attention can open up new ways of understanding what is wrong with American society that cut across the traditional racial divide. ${ }^{451}$ As Jennifer Hochschild has recently noted, African Americans are often "bellwethers" of trends likely to spread throughout the wider community. ${ }^{452}$ The fact that firms are hemorrhaging black lawyers from both the bottom (in the form of talented blacks who either do not get hired or find themselves flatlined) and the top (in the defection of black partners for other opportunities in the public and private sectors) is therefore an important warning sign for the profession as a whole.

Of course, there is no guarantee that any of these "crises" will produce positive effects. Firms that adopt more rationalized management structures may simply ghettoize black lawyers in relatively low status positions. Reform movements in legal education may further entrench existing hierarchies by insuring that blacks who attend lower status law schools receive an education that tracks them into lower paying legal jobs. And, as is all too apparent from much of the current debate over affirmative action, the crisis in American race relations is just as likely to produce obfuscation and demagoguery as it is to illuminate shared problems and open pathways towards new solutions.

Nevertheless, one final aspect of the legal profession's past makes us cautiously optimistic about the ability to make progress on these difficult issues. Few would dispute that the campaign to end legal segregation culminating in Brown v. Board of Education is the legal profession's finest accomplishment-just as the profession's complicity in the regime that this campaign demolished was its darkest hour. The fact that the country's most prestigious law firms are nearly as segre-

450. See, e.g., Jennifer L. Hochschild, Facing Up to the American Dream: Race, Class AND THE SOUL OF THE NATION 211-12 (1995) (reporting that "over two-thirds of black Los Angelenos, compared with roughly two-fifths of whites, Asians, and Latinos, saw the uprising [following the acquittal of the four white police officers in the first Rodney King trial] as 'mainly a protest by blacks against unfair conditions' rather than 'a way of engaging in looting and street crime"'). Black and white responses to the O.J. Simpson verdict are similarly divided.

451. For an example of what can be learned from a careful investigation of this country's current struggle to come to grips with the political and moral significance of race, see ANTHONY Appiah \& Amy Guttmann, Color Consciousness: The Political Morality of Race (forthcoming 1996).

452. See HochSCHLD, supra note 450 , at xii. 
gated today as the entire legal system was forty years ago stands as a constant rebuke to the profession's attempt to claim the noble side of this heritage. At the same time, initiatives such as the Minority Counsel Demonstration Program and the efforts by state and local bar associations to promote workplace diversity demonstrate that the ideals captured by Brown can still energize lawyers to. work for institutional change. As the legal profession confronts the uncertainties of the next millennium, it is this energy that holds the best hope for charting a new path that connects the profession's future to the best of its past. 


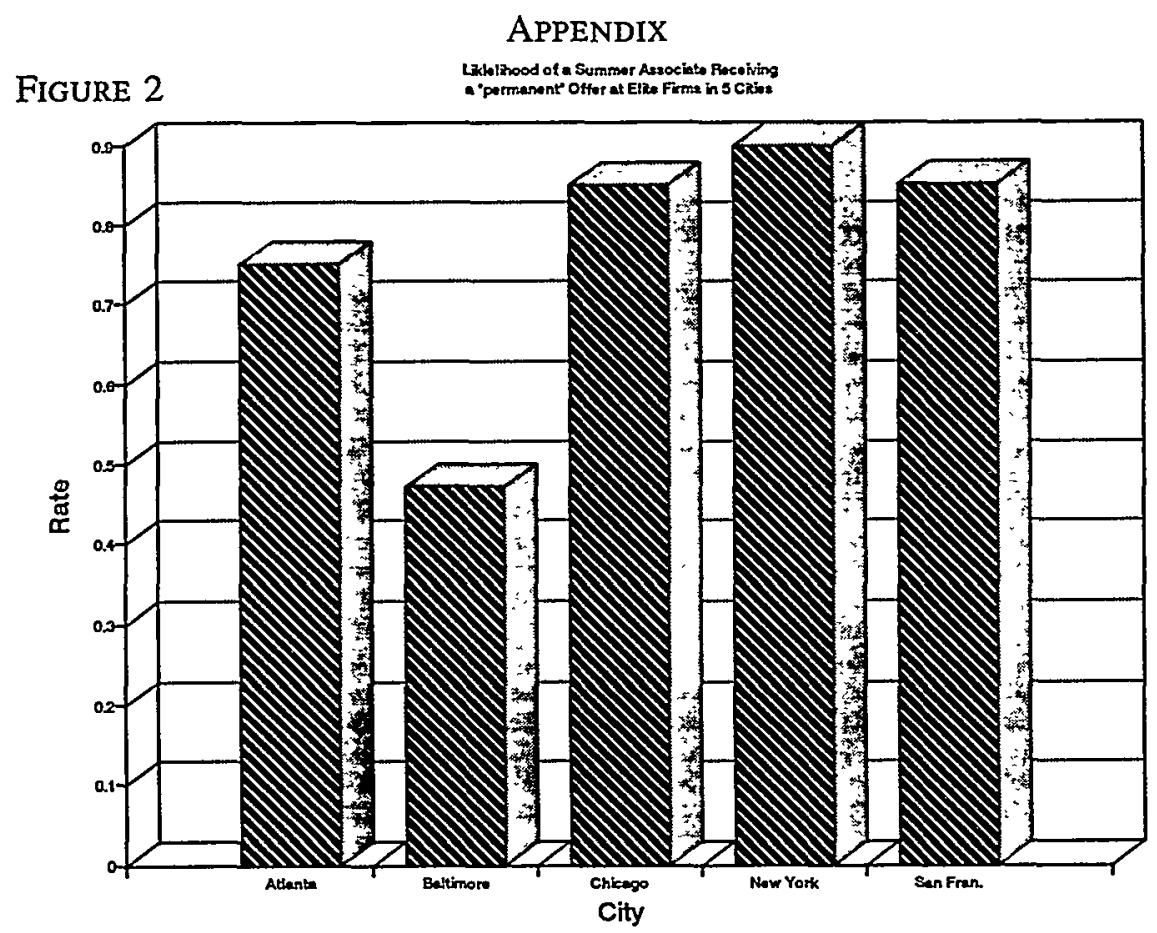

Source: Insider's Guide
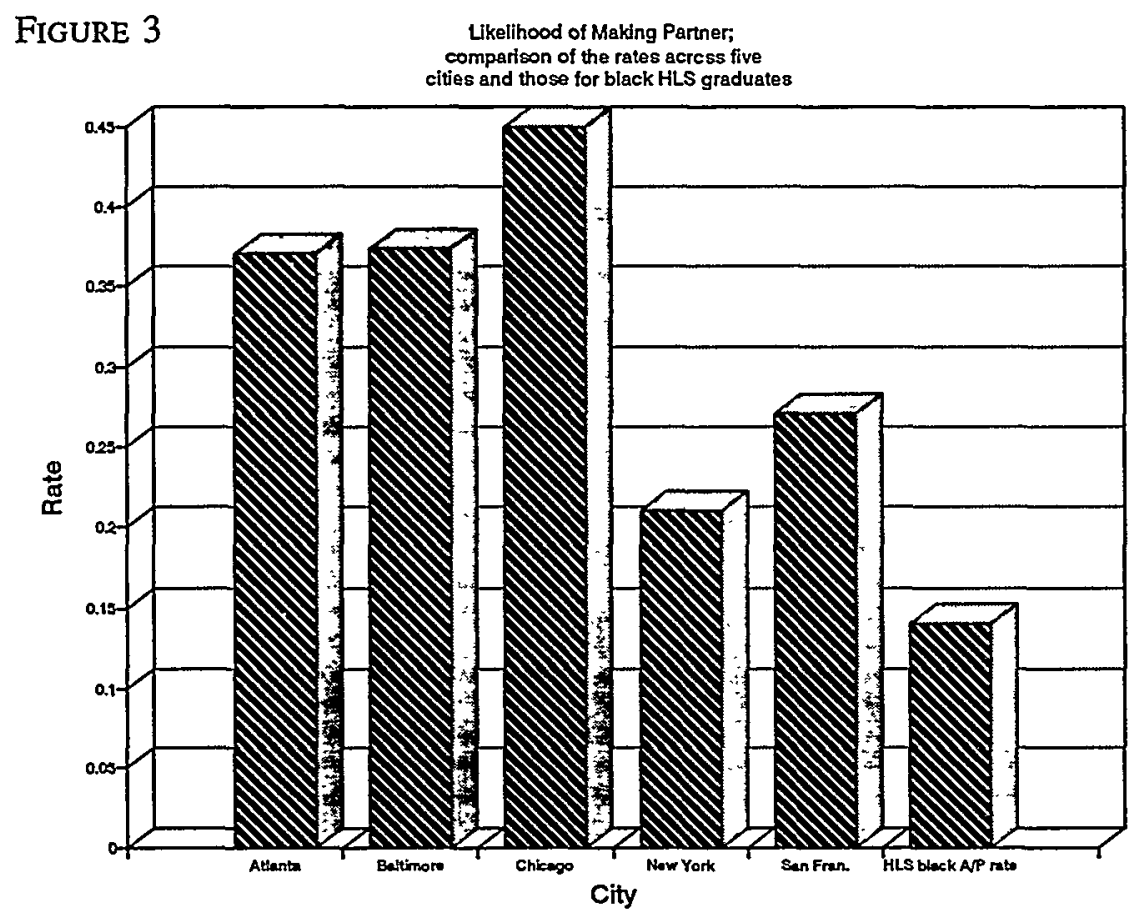

Source: Insider's Guide 
FIGURE 4A

Distribution of Lawyers by Specialty; Atlanta: King \& Spauiding

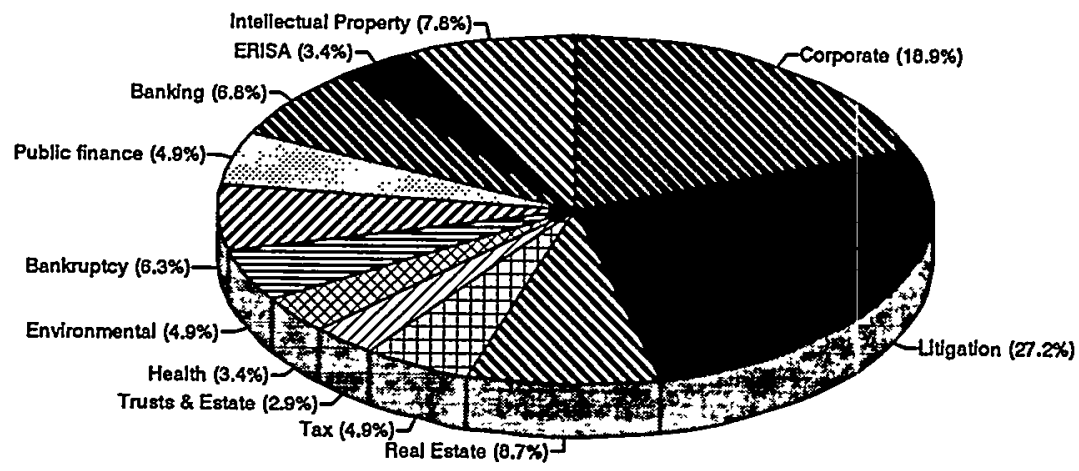

Figure 4B

\section{Source: Insider's Guide}

Distribution of Lawyers by Speciaity;

Chicago: Meyer, Brown \& Platt

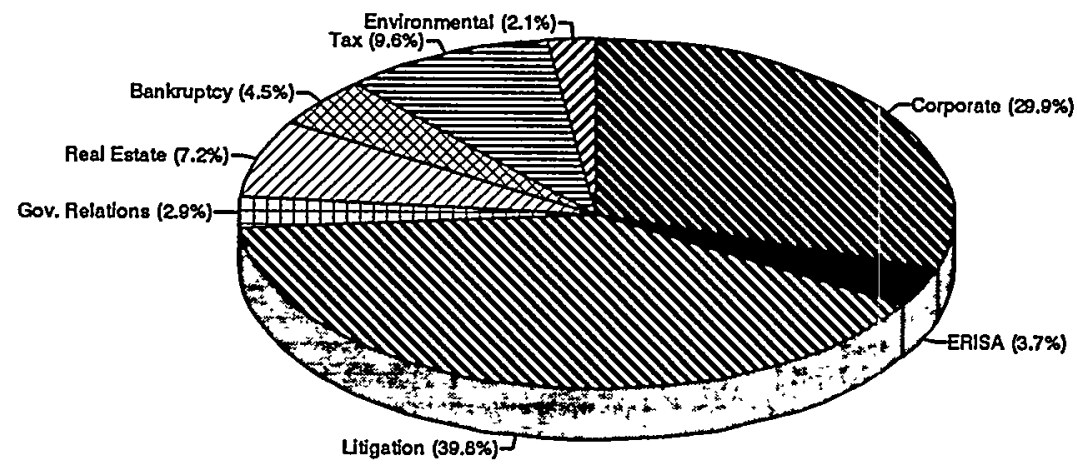

Source: Insider's Guide 


\section{FIGURE 4C}

Distribution of Lawyers by Specialty;

New York: Paul, Weiss, Rifkind, Wharton \& Garrison

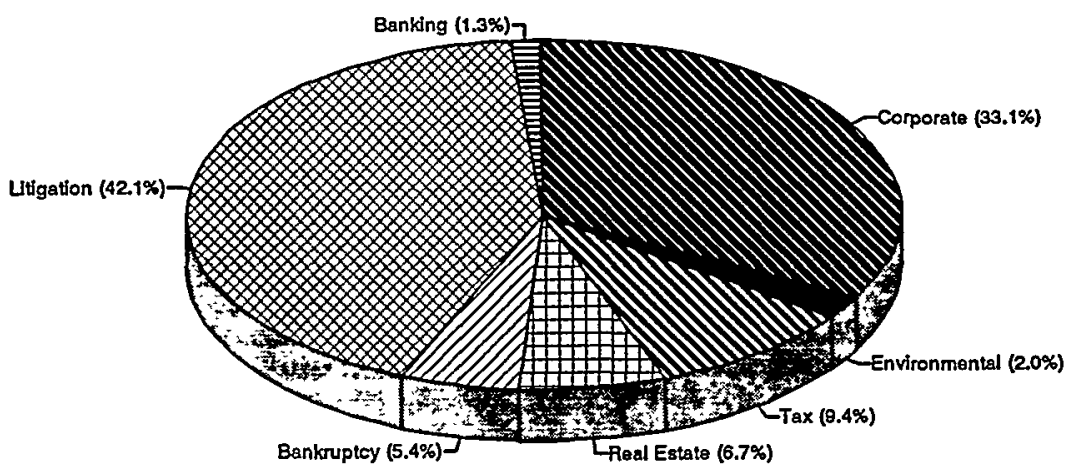

FIGURE 4D

\section{Source: Insider's Guide}

Distribution of Lawyers by Specialty;

San Francisco: Orrick, Herrington \& Sutcliffe

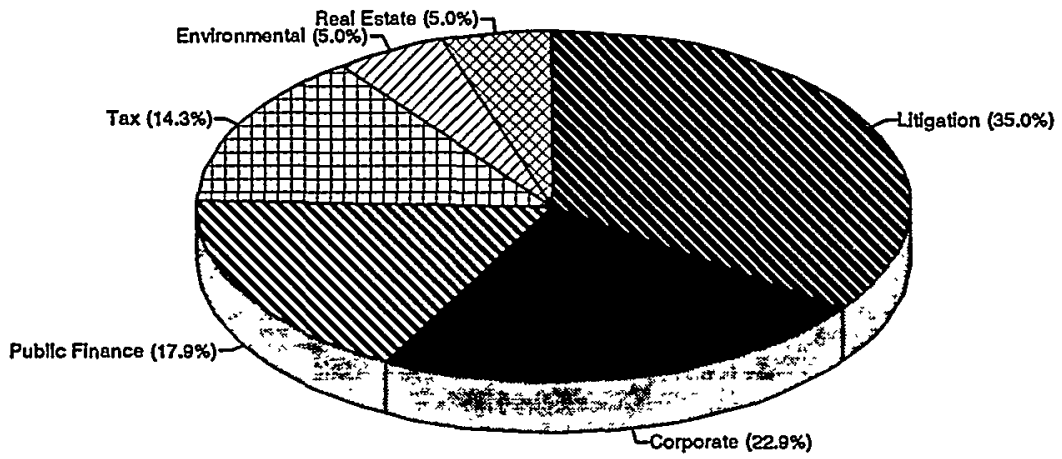

Source: Insider's Guide 
TABLE 1: Data on Black Alumni of Harvard Law School

\begin{tabular}{|l|rr|rr|}
\hline & \multicolumn{3}{|c|}{ Classes of '81 \& '82 } & \multicolumn{2}{|c|}{ Classes of '87 \& '88 } \\
& & $\%$ & & $\%$ \\
\hline Started Out at Elite Law Firms & $36 / 60$ & $60 \%$ & $44 / 57$ & $77 \%$ \\
(not including clerkships): & & & & \\
Were Still at the Same Law Firm in & & & & \\
1993, (Classes of '81 \& '82); & $5 / 36$ & $14 \%$ & $12 / 44$ & $27 \%$ \\
1992, (Classes of '87 \& '88) & & & & \\
Moved into Government After & $5 / 31$ & $16 \%$ & $4 / 32$ & $13 \%$ \\
Their Firm Experience: & & & & \\
Breakdown by Specialty & 18 & $50 \%$ & 17 & $39 \%$ \\
Litigation & 9 & $25 \%$ & 12 & $27 \%$ \\
Corporate & 3 & $8 \%$ & 3 & $7 \%$ \\
Real Estate & 0 & $0 \%$ & 2 & $5 \%$ \\
Entertainment & 6 & $17 \%$ & 9 & $20 \%$ \\
Unknown & 0 & $0 \%$ & 0 & $0 \%$ \\
Public Finance & 0 & $0 \%$ & 1 & $2 \%$ \\
Patent, Tax, Other Specialty & 36 & $100 \%$ & 44 & $100 \%$ \\
& & & & \\
\end{tabular}

Source: Harvard Law School Alumni Office

TABLE 2: Results of Survey of Black Harvard Law School Graduates

\begin{tabular}{|c|c|c|c|c|c|c|}
\hline \multirow[t]{2}{*}{ Table 2, Part A } & \multicolumn{2}{|c|}{$\begin{array}{l}\text { Graduated } \\
\text { Pre-1986 }\end{array}$} & \multicolumn{2}{|c|}{$\begin{array}{c}\text { Graduated } \\
1986+\end{array}$} & \multicolumn{2}{|c|}{ Total } \\
\hline & \# & $\%$ & \# & $\%$ & \# & $\%$ \\
\hline Total Number of Responses & 21 & $100 \%$ & 45 & $100 \%$ & 66 & $100 \%$ \\
\hline Responses from Women & 5 & $24 \%$ & 29 & $64 \%$ & 34 & $52 \%$ \\
\hline $\begin{array}{l}\text { Employment History } \\
\text { Percentage Still Employed at } \\
\text { the firm they joined initially }\end{array}$ & 0 & $0 \%$ & 20 & $44 \%$ & 20 & $30 \%$ \\
\hline $\begin{array}{l}\text { New Jobs of those Who Left } \\
\text { Government }\end{array}$ & 6 & $29 \%$ & 9 & $36 \%$ & 15 & $33 \%$ \\
\hline Small Non-Elite Firm & 2 & $10 \%$ & 6 & $24 \%$ & 8 & $17 \%$ \\
\hline In-House Counsel & 6 & $29 \%$ & 3 & $12 \%$ & 9 & $20 \%$ \\
\hline Private Practice & 1 & $5 \%$ & 1 & $4 \%$ & 2 & $4 \%$ \\
\hline Academia & 1 & $5 \%$ & 2 & $8 \%$ & 3 & $7 \%$ \\
\hline Other Elite Firm & 3 & $14 \%$ & 4 & $16 \%$ & 7 & $15 \%$ \\
\hline InvestmentBanking/Consulting & 2 & $10 \%$ & 0 & $0 \%$ & 2 & $4 \%$ \\
\hline $\begin{array}{l}\text { Number Who Became Partners at } \\
\text { Elite Firms ( } 3 \text { spent time in } \\
\text { Gov't, } 1 \text { in a Small Firm) }\end{array}$ & 4 & $6 \%$ & & & 4 & $6 \%$ \\
\hline
\end{tabular}


TABLE 2: Results of Survey of Black Harvard Law School Graduates (Continued)

\begin{tabular}{|c|c|c|c|c|c|c|}
\hline & \multicolumn{2}{|c|}{$\begin{array}{l}\text { Graduated } \\
\text { Pre-1986 }\end{array}$} & \multicolumn{2}{|c|}{$\begin{array}{c}\text { Graduated } \\
1986+\end{array}$} & \multicolumn{2}{|c|}{ Total } \\
\hline & $\#$ & $\%$ & \# & $\%$ & $\#$ & $\%$ \\
\hline Elite Firm Work Experience & & & & & & \\
\hline Litigation & 11 & $52 \%$ & 19 & $43 \%$ & 30 & $45 \%$ \\
\hline Corporate & 5 & $24 \%$ & 16 & $34 \%$ & 21 & $32 \%$ \\
\hline Real Estate & 3 & $14 \%$ & 4 & $9 \%$ & 7 & $11 \%$ \\
\hline Regulatory & 2 & $10 \%$ & 6 & $14 \%$ & 8 & $12 \%$ \\
\hline Pro Bono Work & & & & & & \\
\hline Did Pro Bono Work & 18 & $86 \%$ & 39 & $87 \%$ & 57 & $86 \%$ \\
\hline $\begin{array}{l}\text { Did Pro Bono Work or Litiga- } \\
\text { tion In Part to Improve Mobil- } \\
\text { ity into Other Employment }\end{array}$ & 1 & $5 \%$ & 15 & $33 \%$ & 16 & $24 \%$ \\
\hline
\end{tabular}

\begin{tabular}{|c|c|c|c|c|c|c|}
\hline \multirow[t]{2}{*}{ Table 2, Part B } & \multicolumn{2}{|c|}{$\begin{array}{l}\text { Graduated } \\
\text { Pre-1986 }\end{array}$} & \multicolumn{2}{|c|}{$\begin{array}{l}\text { Graduated } \\
1986+\end{array}$} & \multicolumn{2}{|c|}{ Total } \\
\hline & \# & $\%$ & $\#$ & $\%$ & \# & $\%$ \\
\hline $\begin{array}{l}\text { Training, Supervison \& Evalua- } \\
\text { tion at the Large Law Firm }\end{array}$ & & & & & & \\
\hline $\begin{array}{l}\text { Had Partners Take Interest in } \\
\text { Their Career }\end{array}$ & $5 / 21$ & $24 \%$ & $21 / 45$ & $47 \%$ & $26 / 66$ & $39 \%$ \\
\hline $\begin{array}{l}\text { If Not, Number for Whom This } \\
\text { Resulted in Their Departure }\end{array}$ & $8 / 16$ & $50 \%$ & $19 / 24$ & $79 \%$ & $27 / 40$ & $68 \%$ \\
\hline $\begin{array}{l}\text { Had Difficulty Getting Good } \\
\text { Work Assignments }\end{array}$ & $12 / 21$ & $57 \%$ & $28 / 45$. & $62 \%$ & $40 / 66$ & $61 \%$ \\
\hline $\begin{array}{l}\text { Whose Difficulty Getting Work } \\
\text { Worsened Over Time }\end{array}$ & $6 / 12$ & $50 \%$ & $20 / 28$ & $71 \%$ & $26 / 40$ & $65 \%$ \\
\hline $\begin{array}{l}\text { Been Through Formal } \\
\text { Review Process* }\end{array}$ & $15 / 21$ & $71 \%$ & $42 / 45$ & $93 \%$ & $57 / 66$ & $86 \%$ \\
\hline $\begin{array}{l}\text { Received Negative Feedback at } \\
\text { the Formal Evaluation that } \\
\text { Wasn't Mentioned Earlier (i.e. } \\
\text { when project completed.) }\end{array}$ & $13 / 21$ & $62 \%$ & $29 / 45$ & $64 \%$ & $42 / 66$ & $64 \%$ \\
\hline $\begin{array}{l}\text { Amount of Criticism Received } \\
\text { Perceived as Being More than a } \\
\text { White Associate at the Same } \\
\text { Level Would Have Received }\end{array}$ & $8 / 21$ & $38 \%$ & $19 / 45$ & $42 \%$ & $27 / 66$ & $41 \%$ \\
\hline
\end{tabular}

\footnotetext{
* Three were too new to have heen through it.
} 
TABLE 2: Results of Survey of Black Harvard Law School Graduates (Continued)

\begin{tabular}{|c|c|c|c|c|c|c|}
\hline Table 2, Part C & \multicolumn{2}{|c|}{$\begin{array}{l}\text { Graduated } \\
\text { Pre-1986 }\end{array}$} & \multicolumn{2}{|c|}{$\begin{array}{c}\text { Graduated } \\
1986+\end{array}$} & \multicolumn{2}{|c|}{ Total } \\
\hline Social Relations & & & & & & \\
\hline $\begin{array}{l}\text { Explicit Racist Comments } \\
\text { While Present }\end{array}$ & $6 / 21$ & $29 \%$ & $15 / 45$ & $33 \%$ & $21 / 66$ & $32 \%$ \\
\hline $\begin{array}{l}\text { If So, Number for Whom This } \\
\text { Was a Major Cause to Leave }\end{array}$ & $0 / 6$ & $0 \%$ & $4 / 15$ & $27 \%$ & $4 / 21$ & $19 \%$ \\
\hline $\begin{array}{l}\text { Felt Welcome Within Social } \\
\text { Networks in the Firm }\end{array}$ & $10 / 21$ & $48 \%$ & $19 / 45$ & $42 \%$ & $29 / 66$ & $44 \%$ \\
\hline $\begin{array}{l}\text { If Not, Number for Whom This } \\
\text { Was a Major Cause to Leave }\end{array}$ & $3 / 11$ & $27 \%$ & $17 / 26$ & $65 \%$ & $20 / 37$ & $54 \%$ \\
\hline $\begin{array}{l}\text { More Under Pressure to be Seen } \\
\text { (e.g., nights and on weekends) }\end{array}$ & $4 / 21$ & $19 \%$ & $15 / 45$ & $33 \%$ & $19 / 66$ & $29 \%$ \\
\hline $\begin{array}{l}\text { Felt Inhibited Discussing Po- } \\
\text { litical, Social, or Moral Views } \\
\text { at the Firm }\end{array}$ & $6 / 21$ & $29 \%$ & $23 / 45$ & $51 \%$ & $29 / 66$ & $44 \%$ \\
\hline $\begin{array}{l}\text { Average Number of Years Be- } \\
\text { fore Departure From the Law } \\
\text { Firm }\end{array}$ & 3.04 & Years & 2.32 & Years & & \\
\hline
\end{tabular}

TABLE 2 QUESTIONNAIRE

\section{Personal History}

Male Female ; HLS Class

Undergraduate Institution

Were you the first in your family to go to law school?

\section{Employment History}

Have you ever been employed full time (i.e., excluding summers) at a corporate law firm with more than 50 lawyers? ; If yes, are you still employed at the firm you joined immediately after graduation? ; If no, how many years did you stay at your first law firm job? ; Did you leave that firm to join another corporate law firm with more than 50 lawyers? ; If so, are you still with this second firm? ; If no, how many years did you spend at the second firm? ___ If you did not join another corporate law firm with more than fifty lawyers after leaving your first law firm job, where did you go (i.e., corporate legal de-partment, small firm, government, etc.)? ; Where are you currently employed? 


\section{Large Law Firm Work Experience}

During your years in corporate law practice, did you work primarily in one practice area?

If so, what was that area? ; If you specialized in litigation, was the possibility of acquiring skills that might improve your marketability to non-corporate law firm employers a substantial motivating factor in your choice of field? ___ Did you do any pro bono work?

If yes, was the possibility of acquiring skills that might improve your marketability to non-corporate law firm employers a substantial motivating factor in your decisionto take on pro bono work?

\section{Training, Supervision, and Evaluation}

Did any of the firm's partners take an active interest in your career (i.e., by providing training, information, or help in selecting good projects)? ; If no, was the sense of this kind of mentoring an important consideration in your decision about whether to stay at the firm?

Did you have difficulty getting good work assignments? ___; If yes, did this problem become worse the longer you stayed at the firm? ; Did you go through a formal evaluation/review process? ; If so, were you ever given negative feedback on your work that was not mentioned at the time the work was completed? ; In either formal or informal discussions with supervising lawyers, have you been criticized for making a mistake that others at your experienced level would not have been criticized for making (or to the same degree)?

\section{Social Relations}

Has anyone ever made an expressly racist statement either to your or in your presence? ; If so, was this a substantial factor in your decision about whether to stay at the firm? ___ Do you feel welcome in the mainstream informal social networks inside your firm? ; If not, is this a substantial factor in your decision about whether to stay at the firm? ; Are you under more pressure to "be seen" at the firm on nights and weekends than your white counter-parts? ; Do you feel inhibited in discussing your political, moral, or social views with other lawyers at the firm?

\section{Follow Up}

If you would be willing to discuss these issues further or to learn more about the project, please put your name and address below. Confidentiality will be strictly observed. 
TABle 3: Results of Law Firm Survey Profile of Entering Associates at 73 Elite Firms

\begin{tabular}{|l|r|}
\hline Total Associates & 1,257 \\
\hline Black Associates & 96 \\
\hline$\%$ of Blacks in Total & $7.6 \%$ \\
\hline Black Associates From Elite Law Schools & 55 \\
\hline$\%$ of Black Associates From Elite Law Schools & $57.3 \%$ \\
\hline Black Associates From HLS & 23 \\
\hline$\%$ of Black Associates From HLS & $24.0 \%$ \\
\hline Non-Black Associates & 1,162 \\
\hline Non-Black Associates From Elite Schools & 601 \\
\hline$\%$ of Non-Black Associates From Elite Schools & $51.7 \%$ \\
\hline Non-Black Associates From HLS & 138 \\
\hline$\%$ of Non-Black Associates From HLS & $11.9 \%$ \\
\hline
\end{tabular}

\begin{tabular}{|c|c|}
\hline $\begin{array}{c}\text { Number of 3L Black Law Students at Schools } \\
\text { From Which Law Firms Hired }\end{array}$ & \\
\hline Number of 3L Black Students at HLS & 61 \\
\hline $\begin{array}{l}\text { Number of 3L Black Students at All Schools } \\
\text { From Which Elite Firms Hired }\end{array}$ & 1,003 \\
\hline$\%$ of HLS Blacks in Total & $6.1 \%$ \\
\hline
\end{tabular}

\begin{tabular}{|l|r|}
\hline \multicolumn{1}{|c|}{ New York } \\
\hline Black Associates & 45 \\
\hline Black Associates From Elite Schools & 29 \\
\hline$\%$ of Black Associates From Elite Schools & $64.4 \%$ \\
\hline Black Associates From HLS, Columbia, NYU & 23 \\
\hline$\%$ of Black Associates From HLS, Columbia, NYU & $51.1 \%$ \\
\hline Black Associates From HLS & 7 \\
\hline$\%$ of Black Associates From HLS & $15.6 \%$ \\
\hline
\end{tabular}

\begin{tabular}{|l|r|}
\hline \multicolumn{2}{|c|}{ Washin ton D.C. } \\
\hline Black Associates & 25 \\
\hline Black Associates From Elite Schools & 1 \\
\hline$\%$ of Black Associates From Elite Schools & $56.0 \%$ \\
\hline Black Associates from HLS, Geor etown & 13 \\
\hline$\%$ of Black Associates From HLS, Geor etown & $52.0 \%$ \\
\hline Black Associates From HLS & 8 \\
\hline$\%$ of Black Associates From HLS & $32.0 \%$ \\
\hline
\end{tabular}


TABLE 4: Distribution of 1995 Entering Black Associates at Elite Law Firms by Law School.

\begin{tabular}{|l|r|}
\hline American & 1 \\
\hline Brooklyn & 1 \\
\hline Boston College & 1 \\
\hline Boston University & 4 \\
\hline Catholic & 1 \\
\hline Columbia & 10 \\
\hline Chicago & 1 \\
\hline Duke & 2 \\
\hline Duquesne & 1 \\
\hline Fordham & 2 \\
\hline Georgetown & 7 \\
\hline George Washington & 3 \\
\hline Georgia State & 1 \\
\hline Harvard & 23 \\
\hline Howard & 4 \\
\hline lllinois & 1 \\
\hline Iowa & 1 \\
\hline Maryland & 1 \\
\hline Michigan & 2 \\
\hline Northwestern & 1 \\
\hline North Carolina Central & 1 \\
\hline Notre Dame & 1 \\
\hline New York University & 9 \\
\hline Pace & 1 \\
\hline Rutgers-Newark & 2 \\
\hline St. John's & 1 \\
\hline Stanford & 2 \\
\hline Tulane & 1 \\
\hline Vanderbilt & 1 \\
\hline Univ. of California-Berkeley & 1 \\
\hline Univ. of California-Los Angeles & 1 \\
\hline University of Pennsylvania & 2 \\
\hline Univ. of Southern California & 1 \\
\hline Univ. of Virginia & 2 \\
\hline Yale & 2 \\
\hline Total & 96 \\
\hline & \\
\hline
\end{tabular}




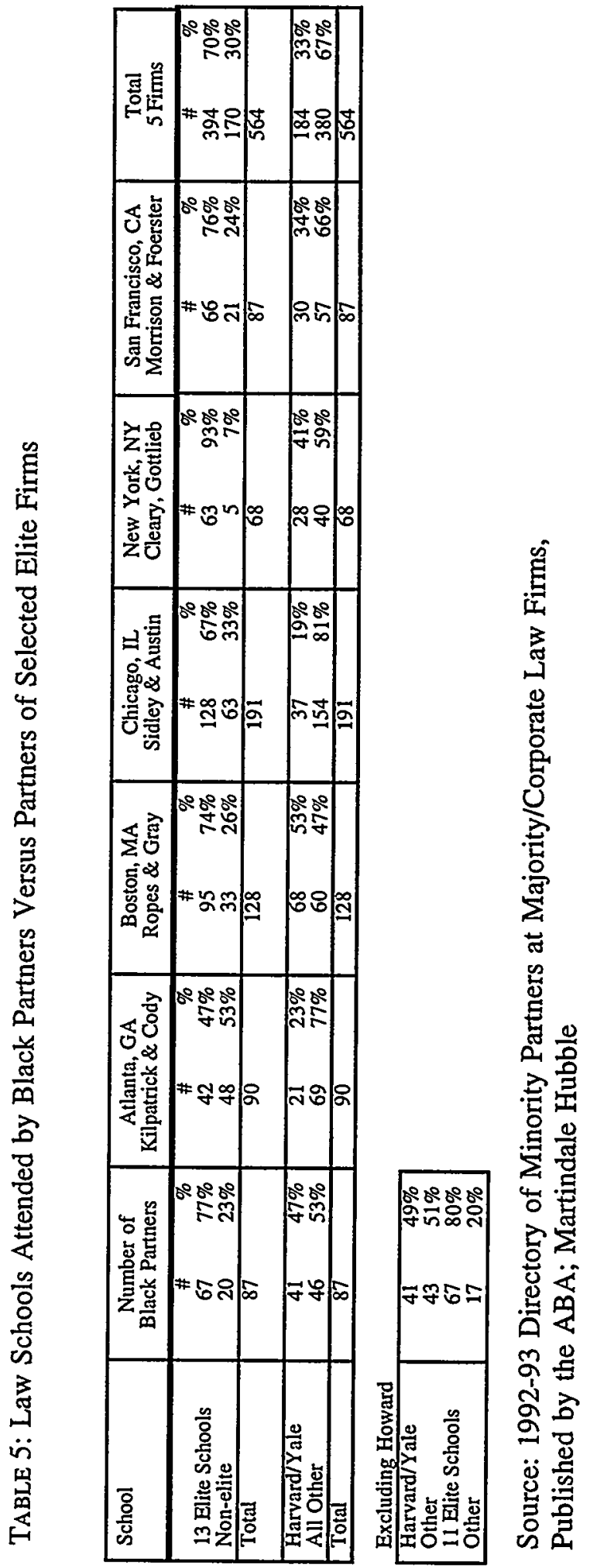


TABLE 6: Summary Data for Black Partners In Elite Firms*

\begin{tabular}{|l|rr|}
\hline \multicolumn{2}{|c|}{$\#$} & $\%$ \\
\hline Total & $\mathbf{8 7}$ & $\mathbf{1 0 0} \%$ \\
Breakdown by Specialty & & \\
Litigation & 49 & $56 \%$ \\
Real Estate & 10 & $11 \%$ \\
Banking Regulatory & 5 & $6 \%$ \\
Bankruptcy & 2 & $2 \%$ \\
Corporate & 12 & $14 \%$ \\
Environmental & 2 & $2 \%$ \\
Municipal/Public Finance & 4 & $5 \%$ \\
Government Legislation & 1 & $1 \%$ \\
ERISA/Tax & 1 & $1 \%$ \\
Entertainment & 1 & $1 \%$ \\
Breakdown by Gender & 62 Men & \\
& 25 Women & \\
Breakdown by Prior Work Experience & & \\
Worked in Government Before Becoming & $32 / 87$ & $37 \%$ \\
Partners & & \\
Worked In-House or as Associates Elsewhere & $24 / 87$ & $28 \%$ \\
Before Becoming Partners & & \\
Were Professors Before Becoming Partners & $10 / 87$ & $11 \%$ \\
Breakdown by Education & & \\
From Ehte Law Schools & & \\
From Harvard and Yale Law Schools & $67 / 87$ & $77 \%$ \\
Not from Elite Law Schools & $41 / 87$ & $47 \%$ \\
Prior Work Experience of Partners Not From & $20 / 87$ & $23 \%$ \\
Elite Law Schools & & \\
Government & & \\
In-House Counsel & $9 / 20$ & $45 \%$ \\
Associates Elsewhere & $1 / 20$ & $5 \%$ \\
Rose Through the Ranks & $2 / 20$ & $10 \%$ \\
Law School Professors & $5 / 20$ & $25 \%$ \\
& $3 / 20$ & $15 \%$ \\
\hline
\end{tabular}

Source: ABA 1992-93 Directory of Partners at Majority/Corporate Law Firms

* We define elite law firms as those firms surveyed by the Insider's Guide (1993). 
